LA-14166

Approved for public release;

distribution is unlimited.

\title{
Thermodynamics of Hydrogen Production
} from Dimethyl Ether Steam Reforming and Hydrolysis

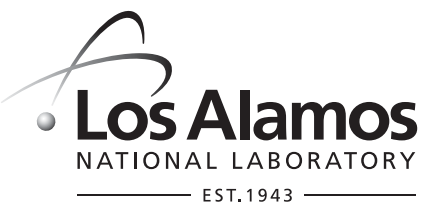


This work was supported by the United States Department of Energy, Hydrogen, Fuel Cells, and Infrastructure Program.

Los Alamos National Laboratory, an affirmative action/equal opportunity employer, is operated by the University of California for the United States Department of Energy under contract W-7405-ENG-36.

This report was prepared as an account of work sponsored by an agency of the United States Government. Neither the Regents of the University of California, the United States Government nor any agency thereof, nor any of their employees make any warranty, express or implied, or assume any legal liability or responsibility for the accuracy, completeness, or usefulness of any information, apparatus, product, or process disclosed, or represent that its use would not infringe privately owned rights. Reference herein to any specific commercial product, process, or service by trade name, trademark, manufacturer, or otherwise does not necessarily constitute or imply its endorsement, recommendation, or favoring by the Regents of the University of California, the United States Government, or any agency thereof. The views and opinions of authors expressed herein do not necessarily state or reflect those of the Regents of the University of California, the United States Government, or any agency thereof. Los Alamos National Laboratory strongly supports academic freedom and a researcher's right to publish; as an institution, however, the Laboratory does not endorse the viewpoint of a publication or guarantee its technical correctness. 
LA-14166

Issued: October 2004

Thermodynamics of Hydrogen Production from

Dimethyl Ether Steam Reforming and Hydrolysis

Troy A. Semelsberger

Rodney L. Borup 



\section{Table of Contents}

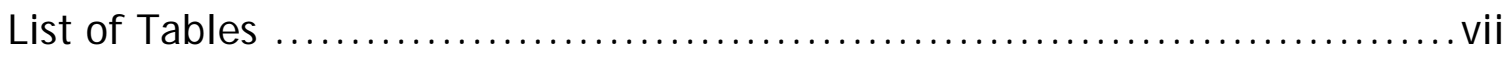

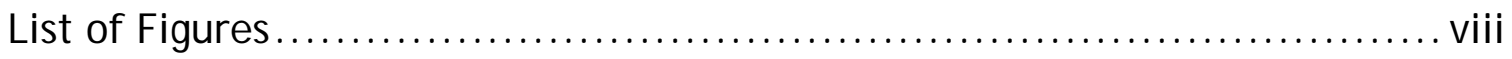

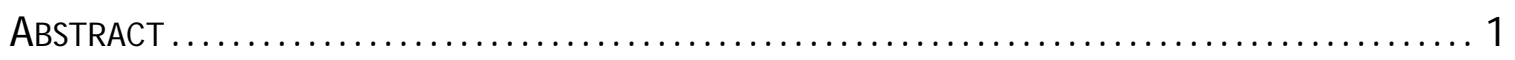

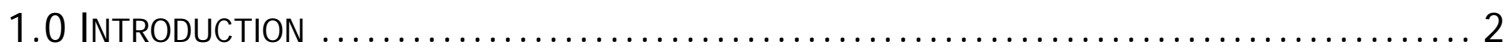

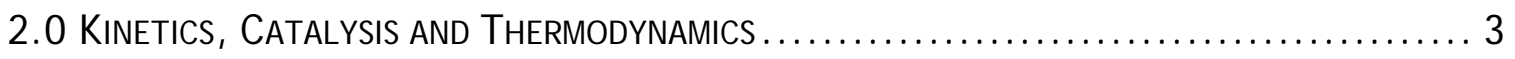

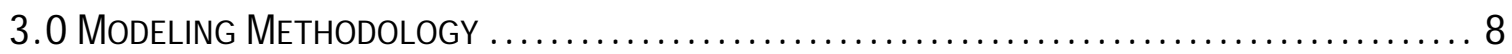

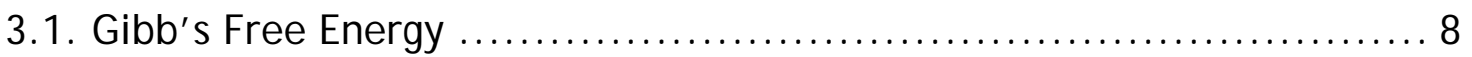

3.2. DME-SR: Primary Reactions, Temperatures and Pressures .............. 11

3. 3. DME-SR: Thermodynamically Viable Products........................ 11

3.4. DME-Hydrolysis: Primary Reactions, Temperatures and Pressures....... 12

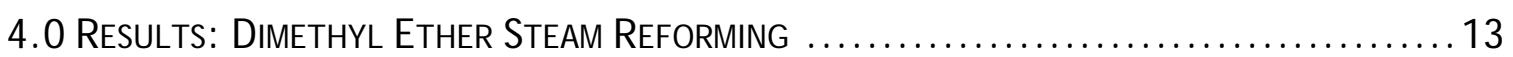

4. 1 DME-SR: Thermodynamic Conversion ................................ 13

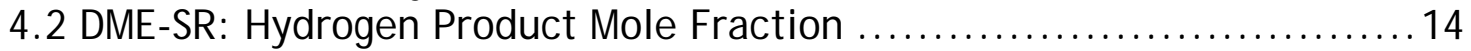

4. 3 DME-SR: Carbon Monoxide Product Mole Fraction...................... 16

5. 0 DME-SR: Optimal Processing for PEM Fuel Cells $\ldots \ldots \ldots \ldots \ldots \ldots \ldots \ldots \ldots \ldots$

5. 1 DME-SR: Pressure Effects Under Optimal Processing Conditions .......... 20

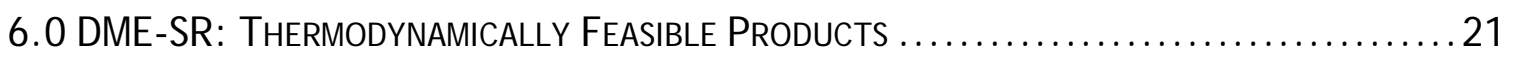

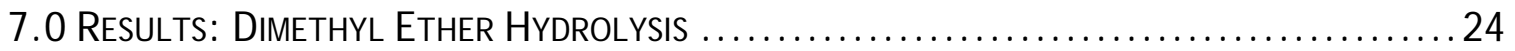

7.1 DME Hydrolysis: Thermodynamic Conversion.......................... 24

7.2 DME Hydrolysis: Optimal Processing Conditions $\ldots \ldots \ldots \ldots \ldots \ldots \ldots \ldots . \ldots \ldots$

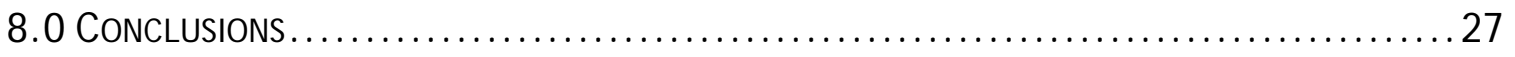

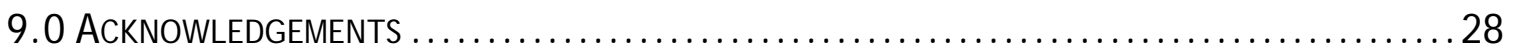

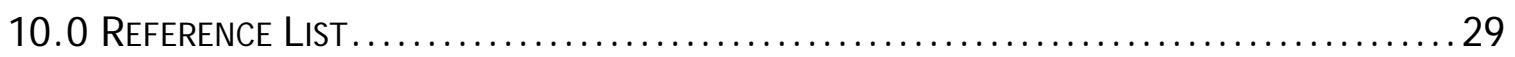

Appendix A: Compilation of Thermodynamic Data for DME-SR on a Wet Basis. . 33

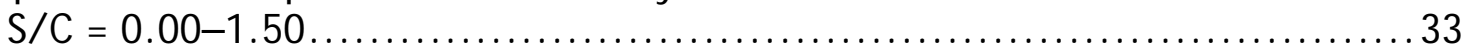

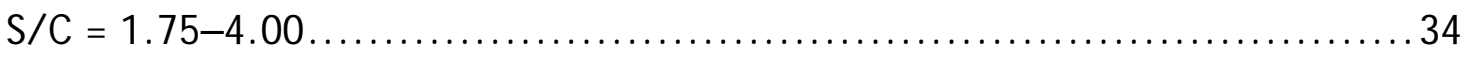

Appendix B: Compilation of Thermodynamic Data for DME-SR on a Dry Basis . . 35

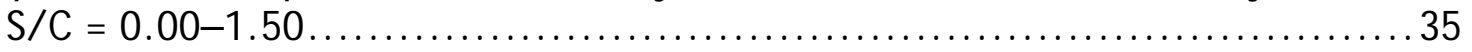

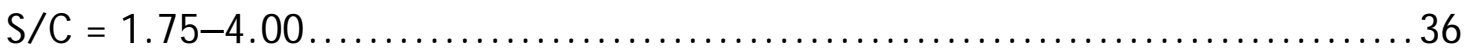


Appendix C: Enlarged Plots of the Thermodynamic Results Contained in the Text

Appendix D: Plot of the DME-SR Hydrogen Production Efficiency on a Wet Basis

Appendix E: DME-SR Carbon Monoxide Plots $\ldots \ldots \ldots \ldots \ldots \ldots \ldots \ldots \ldots \ldots \ldots \ldots$

Appendix F: Compilation of DME-SR Results on a Wet Basis for

Thermodynamically Viable Products Processed at a $\mathrm{S} / \mathrm{C}=2.5$ and $\mathrm{P}=1 \mathrm{~atm}$.. 47

Appendix G: Compilation of DME-SR Results on a Dry Basis for

Thermodynamically Viable Products Processed at a $\mathrm{S} / \mathrm{C}=2.5$ and $\mathrm{P}=1 \mathrm{~atm}$. . 48

Appendix H: Thermodynamic Results for Dimethyl Ether Hydrolysis on a Wet

Basis .................................................................. 49

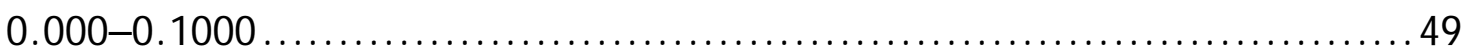

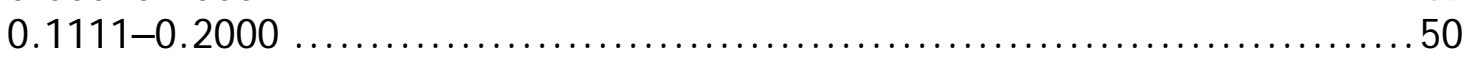

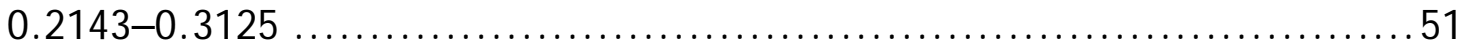

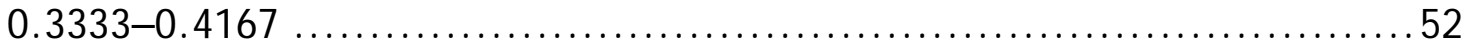

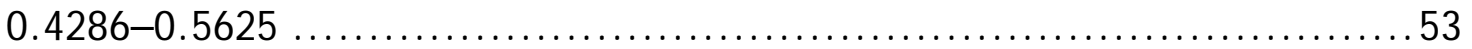

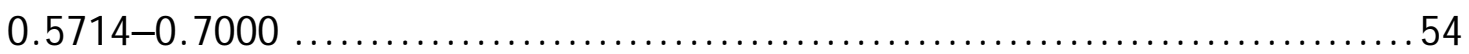

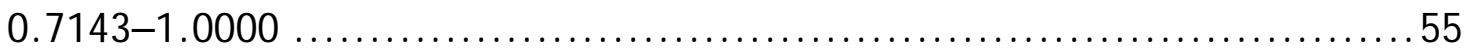

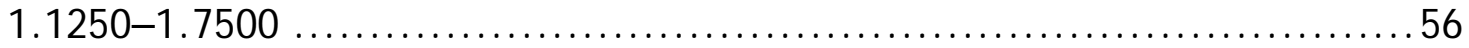

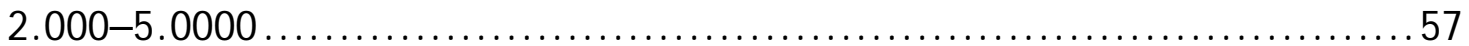




\section{List of Tables}

Table 1. Expanded DME-SR product set at optimal processing conditions. ..... 12

Table 2. Thermodynamic cases for expanded dimethyl ether steam reforming product set with steam-to-carbon ratio of 2.5 and a pressure of $1 \mathrm{~atm} . .22$ 


\section{List of Figures}

Figure 1. Energy diagram illustrating the different equilibrium positions; metastable, constrained and ultimate equilibrium...................... 4

Figure 2. Energy diagram with energy barriers for two different catalysts overlaid; catalyst A is in red and catalyst B is in blue: (a) catalyst A and B have identical activity for product set 1 but different selectivities for product set 2, (b) catalysts A and B have the same selectivity but different activities.

Figure 3. Energy diagram with energy barriers for two different catalysts depicting reduction in activation energy for a given reaction in both the

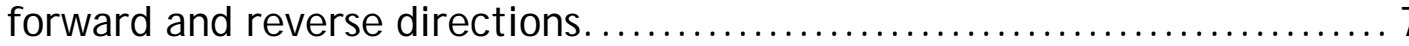

Figure 4. DME-SR modeling methodology flow chart. ...................... 10

Figure 5. Plot of the thermodynamic equilibrium conversion of dimethyl ether as a function of steam-to-carbon ratio and temperature................ 14

Figure 6. Plot of the thermodynamic equilibrium product mole fractions of hydrogen on a (a) wet basis and (b) dry basis as a function of steam-tocarbon ratio and temperature for dimethyl ether-steam reforming; (c) hydrogen production efficiency on a wet basis as a function of steam-tocarbon ratio and temperature.

Figure 7. Plot of the thermodynamic equilibrium-product mole fractions of carbon monoxide on a (a) wet basis and (b) dry basis as a function of steam-to-carbon ratio and temperature for dimethyl ether steam reforming.

Figure 8. Plot of the difference in thermodynamic equilibrium product mole fractions of hydrogen and carbon monoxide on (a) wet basis and (b) dry basis as a function of steam-to-carbon ratio and temperature for dimethyl ether-steam reforming.

Figure 9. Pressure effects on DME-SR compositions of hydrogen and dimethyl ether processed at a temperature of $100{ }^{\circ} \mathrm{C}$ and a steam-to-carbon ratio of 2.5 . 21

Figure 10. Compositions of the most abundant species for thermodynamic cases 1-9 as a function of temperature at a steam-to-carbon ratio of 2.5 and a

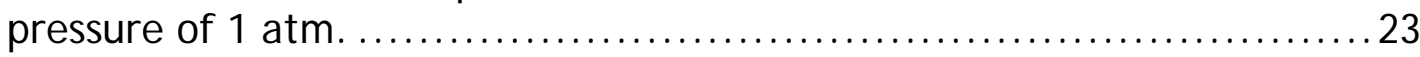

Figure 11. DME equilibrium conversion as a function of temperature and steamto-carbon ratio for the hydrolysis of dimethyl ether. 25 
Figure 12. Effluent equilibrium compositions of methanol on a (a) wet basis and (b) dry basis as a function of temperature and steam-to-carbon ratio for

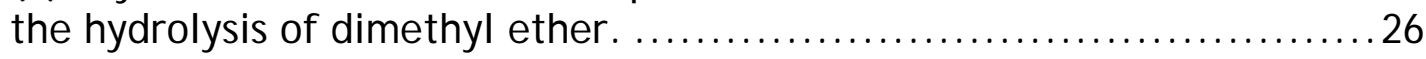





\title{
Thermodynamics of Hydrogen Production from Dimethyl Ether
}

\author{
Steam Reforming and Hydrolysis
}

by

\author{
Troy A. Semelsberger and Rodney L. Borup
}

\begin{abstract}
The thermodynamic analyses of producing a hydrogen-rich fuel-cell feed from the process of dimethyl ether (DME) steam reforming were investigated as a function of steam-to-carbon ratio (0-4), temperature $\left(100^{\circ} \mathrm{C}-600^{\circ} \mathrm{C}\right)$, pressure $(1-5 \mathrm{~atm})$, and product species: acetylene, ethanol, methanol, ethylene, methyl-ethyl ether, formaldehyde, formic acid, acetone, n-propanol, ethane and isopropyl alcohol.

Results of the thermodynamic processing of dimethyl ether with steam indicate the complete conversion of dimethyl ether to hydrogen, carbon monoxide and carbon dioxide for temperatures greater than $200{ }^{\circ} \mathrm{C}$ and steam-to-carbon ratios greater than 1.25 at atmospheric pressure $(\mathrm{P}=1 \mathrm{~atm})$. Increasing the operating pressure was observed to shift the equilibrium toward the reactants; increasing the pressure from 1 atm to $5 \mathrm{~atm}$ decreased the conversion of dimethyl ether from $99.5 \%$ to $76.2 \%$. The order of thermodynamically stable products in decreasing mole fraction was methane, ethane, isopropyl alcohol, acetone, n-propanol, ethylene, ethanol, methyl-ethyl ether and methanol-formaldehyde, formic acid, and acetylene were not observed. The optimal processing conditions for dimethyl ether steam reforming occurred at a steam-to-carbon ratio of 1.5 , a pressure of $1 \mathrm{~atm}$, and a temperature of $200^{\circ} \mathrm{C}$.

Modeling the thermodynamics of dimethyl ether hydrolysis (with methanol as the only product considered), the equilibrium conversion of dimethyl ether is limited. The equilibrium conversion was observed to increase with temperature and steam-to-carbon ratio, resulting in a maximum dimethyl ether conversion of approximately $68 \%$ at a steam-to-carbon ratio of 4.5 and a processing temperature of $600^{\circ} \mathrm{C}$.

Thermodynamically, dimethyl ether processed with steam can produce hydrogenrich fuel-cell feeds-with hydrogen concentrations exceeding 70\%. This substantiates dimethyl ether as a viable source of hydrogen for PEM fuel cells.
\end{abstract}




\subsection{INTRODUCTION}

With ever tightening restrictions on pollutants and emission standards to address the growing concern for the environment, the world is seeking alternative power generating technologies that will supplant inefficient technologies of the past. Fuel cell technology is anticipated to spearhead the transition to more efficient methods of producing power. Fuel cell technology has generated widespread interest within the political arena as a technology that will remove or relax the dependency on oil.

Oil is the main source of energy within the United States for transportation; however, with the advent of more efficient methods of producing power, such as fuel cells, the dependency on foreign oil can be relaxed, though not removed. A means of removing the dependency on foreign oil is to implement fuels derived from renewable sources such as Fischer-Tropsch fuels or fuels such as methane, biomass and coal, which are more ubiquitous in nature. For this reason, a wide range of alternative fuels are being researched, including: methanol, methane, ethanol, biodiesel and biogasoline.

Dimethyl ether (DME) is another alternative fuel that has not attracted much attention as a hydrogen carrier for fuel cells, although it has good potential because of its low temperature-reforming aspects.[1-9] The production of dimethyl ether occurs over zeolite-based catalysts with syngas as the raw material.[10-21] Unlike many of the fuels considered for production of hydrogen-rich fuel-cell feeds, dimethyl ether is nontoxic, noncarcinogenic, nonteratogenic and nonmutagenic. Dimethyl ether has already penetrated the commercial sector in the form of aerosol propellants (e.g., Dymel $\mathrm{A}^{\mathrm{TM}}$ ) with typical uses as bronchodilators, shaving cream, perfume and spray paint. Dimethyl ether has also found uses as a refrigerant and as a diesel substitute and additive.[1;22-31] As both a diesel substitute and additive, dimethyl ether has demonstrated a decrease in NOx, SOx, and particulate matter.[24;32-34] The use of DME as a clean fuel, including use for household heating and cooking fuel, (thereby eliminating the need for liquefied petroleum gases) is being considered.[35;36] Japan is anticipating a dimethyl ether infrastructure to be implemented by the end of the decade.The many uses exemplify the relatively benign nature of dimethyl ether with respect to humans and the environment. 
The storage and handling of dimethyl ether is similar to those of liquefied petroleum gases (LPG); e.g., butane and propane; therefore, the infrastructure of LPG fuels can be readily used for the distribution of dimethyl ether. In addition, the existing natural gas infrastructure can also be used to distribute DME. Consequently, dimethyl ether may be a viable alternative to the leading fuels for the production of hydrogen.

This paper investigates the thermodynamics of producing hydrogen-rich fuel-cell feeds from the process of dimethyl ether steam reforming. This research augments the work published by Sobyanin et al. [5] who investigated the effects of temperature $\left(327^{\circ} \mathrm{C}-727^{\circ} \mathrm{C}\right)$, pressure $(1-5 \mathrm{~atm})$ and steam-to-carbon ratios $(0.5-10)$ for dimethyl ether steam reforming. Our study expands upon the previous research by examining lower temperatures $\left(100^{\circ} \mathrm{C}-600^{\circ} \mathrm{C}\right)$ and expanding the product set to consist of hydrogen, carbon monoxide, carbon dioxide, acetylene, ethanol, methanol, ethylene, methyl-ethyl ether, formaldehyde, formic acid, acetone, n-propanol, ethane, and isopropyl alcohol.

\subsection{Kinetics, Catalysis and Thermodynamics}

This section addresses the implications of kinetics, catalysis and thermodynamics on the steam reforming of dimethyl ether. The Gibb's free energy function and its minimization is a state function, thus implying the independence of path. Equivalently, the minimization of this function, given an initial and final state, can be viewed hypothetically as having an infinite number of paths, all of which have an equal probability of occurrence (path independent or selectivity invariant) or equivalently all paths have identical rates of reaction; i.e., time invariant. The constraint of the products or the final state will dictate the Gibb's minimum energy and thus the thermodynamic compositions. This can be illustrated with a potential energy diagram, as in Figure 1, where the reactants (or the initial state) are in metastable equilibrium. The metastable equilibrium state for dimethyl ether steam reforming is dimethyl ether and water. 


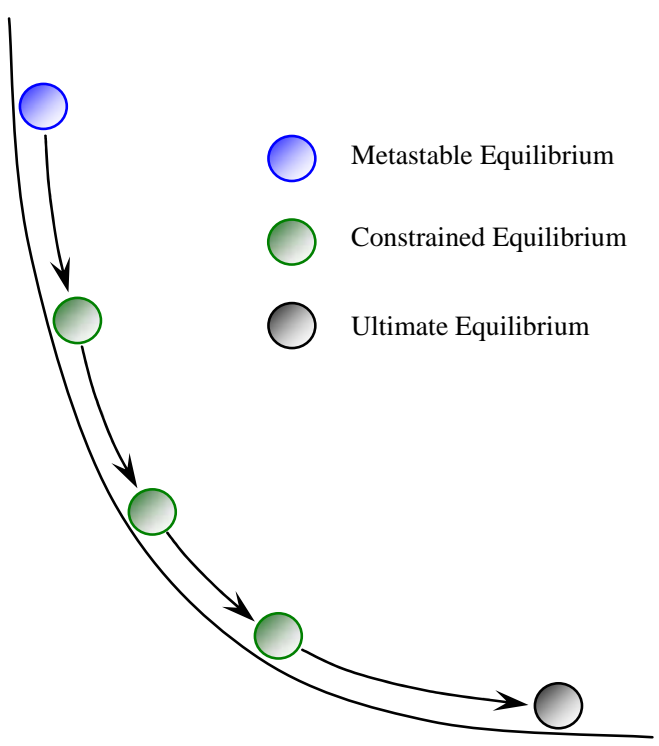

Figure 1. Energy diagram illustrating the different equilibrium positions; metastable, constrained and ultimate equilibrium.

Ultimate equilibrium is the global minimization of Gibb’s free energy, depicted at the bottom of the energy diagram. Ultimate equilibrium results in the most stable thermodynamic products. Methane, carbon, carbon monoxide and water, because of their stability, usually predominate. From an economic standpoint, ultimate equilibrium is usually undesired. Constrained equilibrium is the position dictated by products chosen as the final state. Constrained equilibrium is equivalent to imposing a selectivity constraint that in practice is experimentally observed to be a function of a catalyst employed and is often known a priori to performing thermodynamic calculations.

For example, the target products of dimethyl ether steam reforming are hydrogen and carbon dioxide (Equation 1), but the product set observed in practice includes carbon monoxide (Equation 2). Therefore the constrained equilibrium would include carbon monoxide, carbon dioxide and hydrogen as the product set that results in a local minimization of Gibb's free energy. This is not the ultimate equilibrium position (Equation 4), which includes carbon, methane, carbon monoxide, etc. 


$$
\begin{array}{ll}
\mathrm{CH}_{3} \mathrm{OCH}_{3}+3 \mathrm{H}_{2} \mathrm{O} \rightleftharpoons 2 \mathrm{CO}_{2}+6 \mathrm{H}_{2} & \text { Constrained Equilibrium } \\
\mathrm{CH}_{3} \mathrm{OCH}_{3}+2 \mathrm{H}_{2} \mathrm{O} \rightleftharpoons \mathrm{CO}+\mathrm{CO}_{2}+5 \mathrm{H}_{2} & \text { Constrained Equilibrium } \\
\mathrm{CH}_{3} \mathrm{OCH}_{3}+\mathrm{H}_{2} \mathrm{O} \rightleftharpoons \text { hydrocarbons } & \text { Constrained Equilibrium } \\
\mathrm{CH}_{3} \mathrm{OCH}_{3}+\mathrm{H}_{2} \mathrm{O} \rightleftharpoons \mathrm{C}, \mathrm{CO}, \mathrm{CH}_{4}, \mathrm{H}_{2} \text {, etc. } & \text { Ultimate Equilibrium }
\end{array}
$$

Because systems seek the lowest possible energy state, the question arises, why do we not see products that are thermodynamically favored, as in ultimate equilibrium? The reason that a single reaction out of many may be selectively promoted is that an effective catalyst lowers the activation barrier and therefore accelerates the rate of desired reaction. Because the relative rates of the competing reactions are extremely slow, the condition of constrained equilibrium is observed. If we overlay the kinetic parameters on an energy diagram (Figure 2) the ideas of selectivity, rates, and constrained equilibrium can be further elucidated.

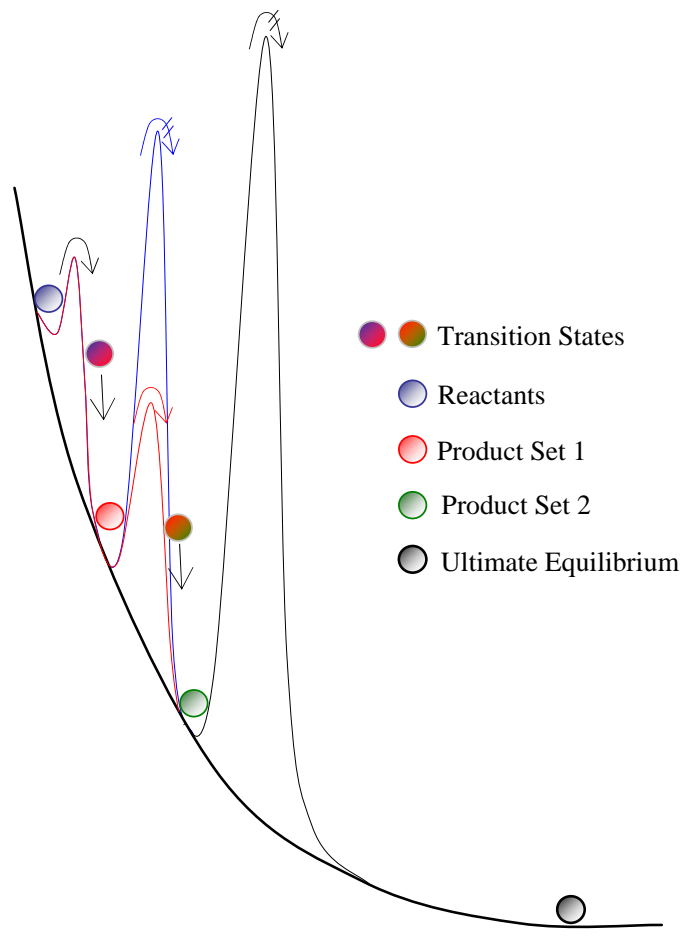

(a)

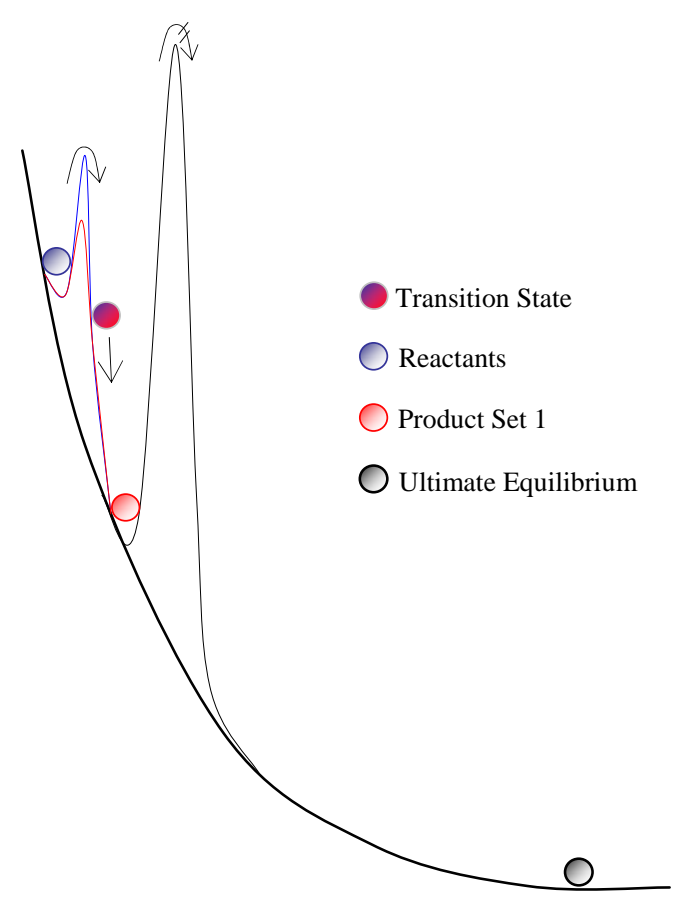

(b)

Figure 2. Energy diagram with energy barriers for two different catalysts overlaid; catalyst $A$ is in red and catalyst B is in blue: (a) catalyst A and B have identical activity for product set 1 but different selectivities for product set 2, (b) catalysts A and B have the same selectivity but different activities. 
The activation barriers are the energy barriers that separate the products and reactants and must be overcome for the reaction to proceed. The height of the barrier represents the relative rate of reaction for a given catalyst. The arrow at the top of the activation barrier indicates the path from products to reactants. If the arrow has a double line through it, then the rate of reaction is too slow for the reaction to take place. Figure 2 also illustrates the different product sets represented by the different equilibrium positions on the energy diagram. The products lower in energy are the products that produce a lower Gibb's free energy and represent different constrained equilibria. Ultimate equilibrium is depicted as the lowest possible energy state that can be achieved.

Figure 2a represents the scenario where the rates of reaction for both catalysts are equivalent (i.e., same barrier height) for product set 1 , but catalyst $A$ has a lower activation barrier for product set 2 than catalyst B, and therefore catalyst A will also produce product set 2, but catalyst B does not. This illustrates dissimilar selectivities for different catalysts with identical activities. Figure $2 \mathrm{~b}$ illustrates the case where the two catalysts have identical selectivities but different activities.

Although catalyst selectivity is observed to determine the product set; i.e., constrained equilibrium, the catalyst affects only the rate of reaction and not the equilibrium state of the promoted reaction. For example, the hydrolysis of dimethyl ether to methanol, as will be shown, is thermodynamically limited with regard to dimethyl ether conversion. Thus, two different catalysts with identical selectivities for the hydrolysis of dimethyl ether may have different reaction rates, but neither will alter the maximum conversion of dimethyl ether. This is the principle of microscopic reversibility and is clarified in Figure 3. The principle of microscopic reversibility states that every reaction is reversible, even though the reverse reaction may be extremely slow. 


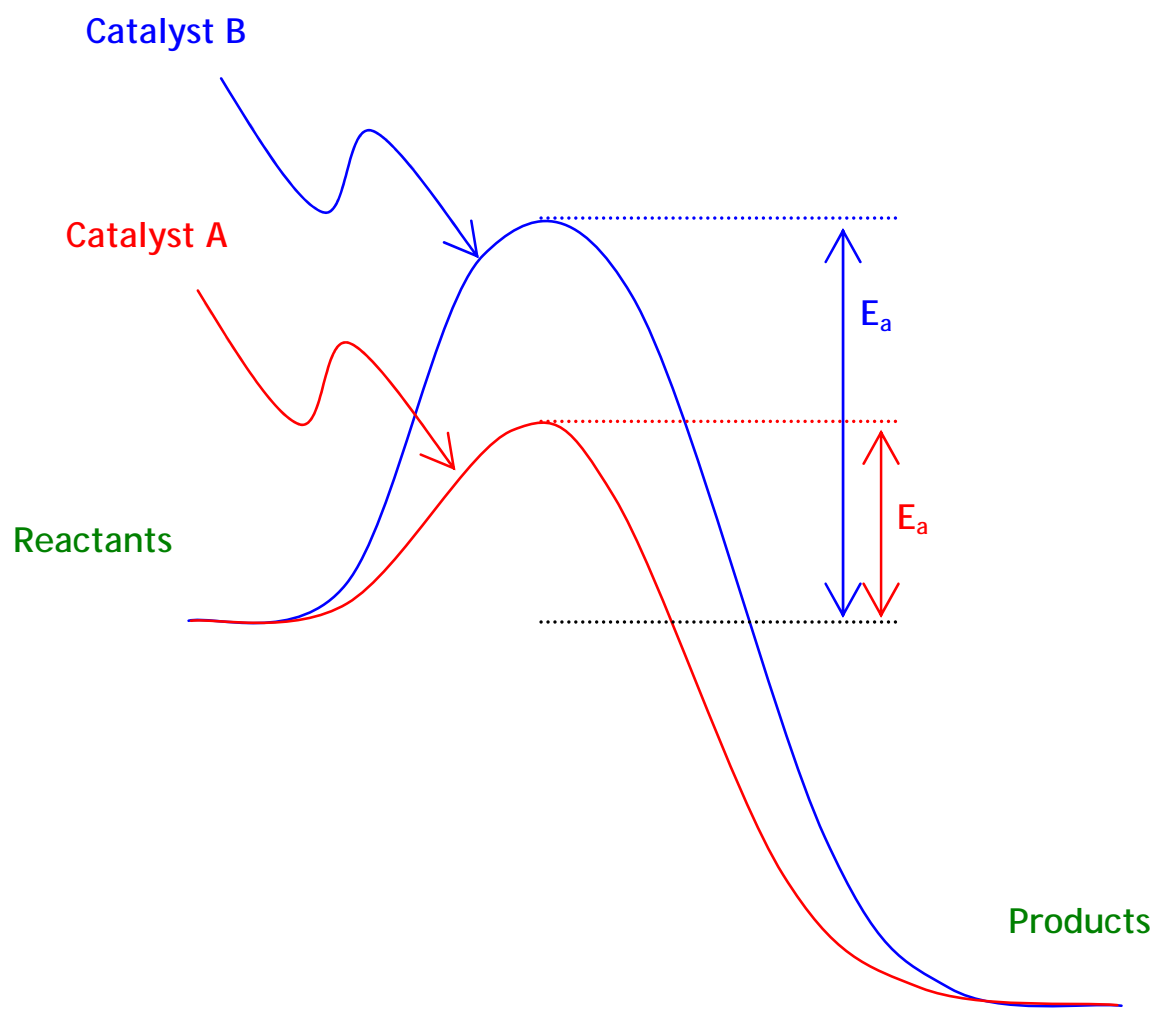

Figure 3. Energy diagram with energy barriers for two different catalysts depicting reduction in activation energy for a given reaction in both the forward and reverse directions.

As shown, catalyst A lowers the activation barrier, thus increasing the rate of reaction compared to catalyst $B$. If catalyst $A$ increases the forward rate two-fold, then it must increase the reverse rate by two-fold. Furthermore, a catalyst that lowers the activation energy in one direction must necessarily lower the barrier in the opposite direction by the same amount. This is why a catalyst does not affect the equilibrium composition, but only the rates of the forward and reverse reactions. Consequently, thermodynamic equilibrium calculations result in the lowest energy state that can be achieved. Therefore, for equilibrium calculations, the identity of the catalyst is not required as long as the promoted reaction(s), or equivalently the constrained equilibrium position(s) are known. 


\subsection{Modeling Methodology}

Chemical reactions are in equilibrium when the forward rate is identical to the reverse rate. For a given reaction, the concentrations of reactant species change with time until both reactions (the forward and its reverse reaction) proceed at the same rate. The relative proportions of the reacting species are determined by the state of equilibrium, which may be altered by changing the pressure and/or temperature. This is commonly known has Le Chatelier’s principle.

\subsection{Gibb's Free Energy}

The method employed for determining the equilibrium compositions involved the Gibb’s free energy and its minimization. The Gibb’s free energy equations that were minimized are shown, without derivation, in Equation 1. For a complete derivation of the equations, refer to Perry’s Chemical Engineers’ Handbook.[37]

$$
\Delta G_{f i}^{o}+R T \ln P+R T \ln y_{i}+R T \ln \hat{\phi}_{i}+\sum_{k}\left(\lambda_{k} a_{i k}\right)=0
$$

Subject to the Constraints,

$$
\sum_{i}\left(y_{i} a_{i k}\right)=A_{k} / \sum_{i} n_{i} \quad \text { and } \quad \sum_{i} y_{i}=1
$$

where

$\Delta G_{f i}^{o}=$ standard Gibbs function of formation of compound $i$

$R=$ molar gas constant

$T=$ processing temperature

$P=$ processing pressure

$y_{i}=$ gas phase mole fraction of compound $i$

$\hat{\phi}_{i}=$ fugacity coefficient of compound $i$

$\lambda_{\mathrm{k}}=$ Lagrange multiplier

$a_{i k}=$ number of atoms for kth element of species $i$

$A_{k}=$ total mass of kth element

$n_{i}=$ moles of compound $i$ 
All equilibrium calculations were assumed to be homogeneous; i.e., no solid or liquid phases. The equation of state used was the Peng-Robinson equation. The minimization was accomplished with the use of Aspen $\mathrm{Tech}^{\mathrm{TM}}$, commercial software capable of performing multicomponent equilibria.

The modeling methodology is represented by the flow chart in Figure 4. There are four "steps" to calculating chemical equilibrium;

1. Choose reactants and their relative proportions,

2. Choose products,

3. Choose processing temperature and pressure, and

4. Perform minimization. 


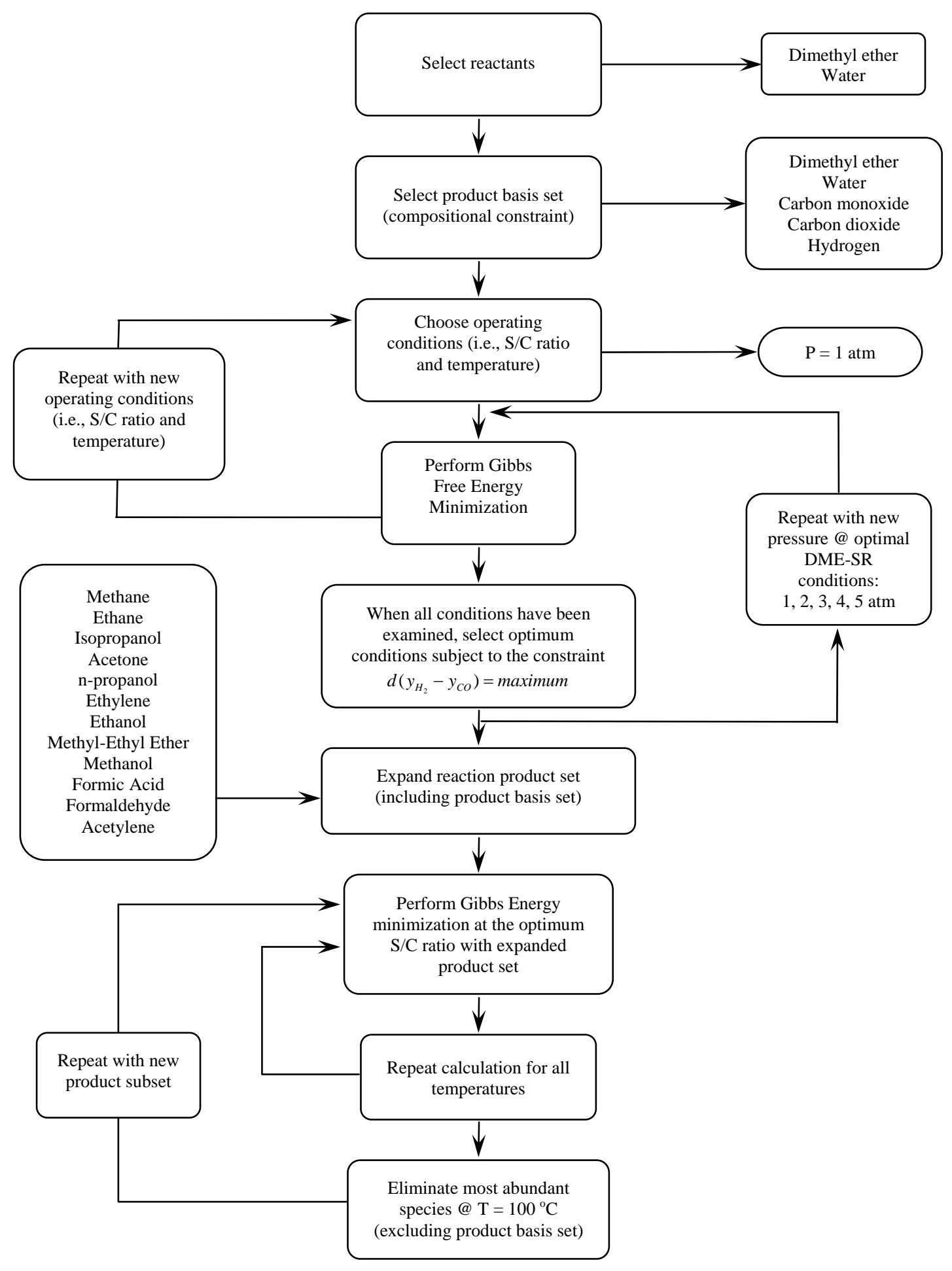

Figure 4. DME-SR modeling methodology flow chart. 


\subsection{DME-SR: Primary Reactions, Temperatures and Pressures}

The primary reactions and temperatures chosen for the initial equilibrium modeling were based on experimental observations.[9] The reactions, or equivalently, the constrained equilibria, are

$$
\begin{aligned}
& \text { DME - SR: } \mathrm{CH}_{3} \mathrm{OCH}_{3}+3 \mathrm{H}_{2} \mathrm{O}(\mathrm{v}) \rightleftharpoons 2 \mathrm{CO}_{2}+6 \mathrm{H}_{2} \quad \Delta \mathrm{H}_{r}^{o}=+135 \mathrm{~kJ} / \mathrm{mol} \\
& \text { WGS : } \mathrm{H}_{2}+\mathrm{CO}_{2} \rightleftharpoons \mathrm{H}_{2} \mathrm{O}(\mathrm{v})+\mathrm{CO} \quad \Delta H_{r}^{o}=+41 \mathrm{~kJ} / \mathrm{mol} \\
& \mathrm{CH}_{3} \mathrm{OCH}_{3}+2 \mathrm{H}_{2} \mathrm{O}(\mathrm{v}) \rightleftharpoons \mathrm{CO}_{2}+5 \mathrm{H}_{2}+\mathrm{CO} \quad \Delta \mathrm{H}_{r}^{o}=+176 \mathrm{~kJ} / \mathrm{mol} .
\end{aligned}
$$

Both reactions are endothermic in the forward direction, with dimethyl ethersteam reforming roughly three times the energy requirement as the forward water gas shift reaction. The sum of the two equations, results in a composite reaction with a large endothermic heat load, $176 \mathrm{~kJ}$ per mol. The composite reaction was taken as the product basis set $\left(\mathrm{CH}_{3} \mathrm{OCH}_{3}, \mathrm{H}_{2} \mathrm{O}, \mathrm{CO}_{2}, \mathrm{CO}, \mathrm{H}_{2}\right)$. The temperature and pressure ranges investigated were $100^{\circ} \mathrm{C}-600^{\circ} \mathrm{C}$ and $1-5 \mathrm{~atm}$ respectively, with steam-to-carbon ratios ranging from 0.0 to 4.0 .

Given the processing temperatures and products, the equilibrium compositions were calculated. The equilibrium compositions were mapped for each condition, and the optimal processing temperature and feed composition were determined. The processing pressure was then varied to ascertain its effects on the equilibrium composition.

\subsection{DME-SR: Thermodynamically Viable Products}

Depending on the operating conditions (specifically the catalysts employed) the product distribution may be different than those assumed above $\left(\mathrm{CH}_{3} \mathrm{OCH}_{3}, \mathrm{H}_{2} \mathrm{O}, \mathrm{CO}_{2}\right.$, $\mathrm{CO}, \mathrm{H}_{2}$ ). The product set was expanded to include products that may be intermediates and/or structural isomers. The expanded product set can be seen in Table 1. Although the reactions involving the chemical species in the expanded product set are not explicitly defined, they are, however, defined implicitly. 
To further explore the thermodynamically viable products under various degrees of selectivity; the species with the largest effluent mole fraction at a temperature of $100^{\circ} \mathrm{C}$ and the optimal steam-to-carbon ratio was removed from the product set - with the exception of the products in the basis set; then the calculations were repeated, thus defining a new thermodynamic case study. In all cases, the product sets did not include carbon as a thermodynamically viable species. Carbon was excluded because the rate of carbon formation is experimentally observed to be slow, and the catalysts employed for the process of dimethyl ether steam reforming are unlikely to promote carbon formation.

\section{Expanded Product Set}

$\begin{array}{ll}\text { Acetone } & \begin{array}{l}\text { Formic Acid } \\ \text { Acetylene }\end{array} \\ \text { Carbon Dioxide* } & \begin{array}{l}\text { Hydrogen* } \\ \text { Isopropanol }\end{array} \\ \text { Carbon Monoxide* } & \text { Methane } \\ \text { Dimethyl Ether }(D M E)^{*} & \text { Methanol } \\ \text { Ethane } & \text { Methyl-Ethyl Ether } \\ \text { Ethanol } & n \text {-Propanol } \\ \text { Ethylene } & \text { Water* } \\ \text { Formaldehyde } & \end{array}$

* Product Basis Set

Table 1. Expanded DME-SR product set at optimal processing conditions.

\subsection{DME-Hydrolysis: Primary Reactions, Temperatures and Pressures}

The thermodynamics of DME hydrolysis to methanol was modeled to quantify constraints imposed thermodynamically, such as temperature and conversion. The only thermodynamic product considered from the hydrolysis of DME was methanol:
DME Hydrolysis : $\mathrm{CH}_{3} \mathrm{OCH}_{3}+\mathrm{H}_{2} \mathrm{O} \underset{\text { Catalyst }}{\stackrel{\text { Acid }}{\rightleftarrows}} 2 \mathrm{CH}_{3} \mathrm{OH}$

$$
\Delta H_{r}^{0}=+37 \mathrm{~kJ} / \mathrm{mol} .
$$


The thermodynamics of this reaction are important, as the concentrations of methanol and dimethyl ether will equilibrate via the reaction equilibrium constant during the steam reforming of DME. During syngas conversion to higher molecular weight hydrocarbon, methanol is an observed intermediate. This reaction occurs over acid catalysts, where syngas is first converted to methanol, whereby methanol establishes equilibrium with dimethyl ether via the DME hydrolysis reaction. Dimethyl ether and methanol are then converted into higher molecular-weight products. For this reason methanol is an intermediate in the process of dimethyl ether-steam reforming and is observed experimentally over acid catalysts.[9;12;21;38-45]

The temperature range investigated was identical to the temperature range used for the process of dimethyl ether steam reforming. Because there is no molar change in the hydrolysis of dimethyl ether, a change in pressure will not shift the equilibrium therefore, the processing pressure was maintained at 1 atmosphere.

\subsection{Results: Dimethyl Ether Steam Reforming}

\subsection{DME-SR: Thermodynamic Conversion}

Figure 5 illustrates the equilibrium conversion of dimethyl ether as a function of steam-to-carbon ratio and temperature. The conversion of DME approaches 1 for all practical operating conditions (i.e., $\mathrm{T}>200^{\circ} \mathrm{C}$ and $\mathrm{S} / \mathrm{C}>1.5$ ). The steam reforming of dimethyl ether is not thermodynamically limited by conversion.

The dimethyl ether steam reforming results on a wet and dry basis in tabular form are in Appendices A and B, respectively. Appendix C contains larger versions of the plots contained in the text. 


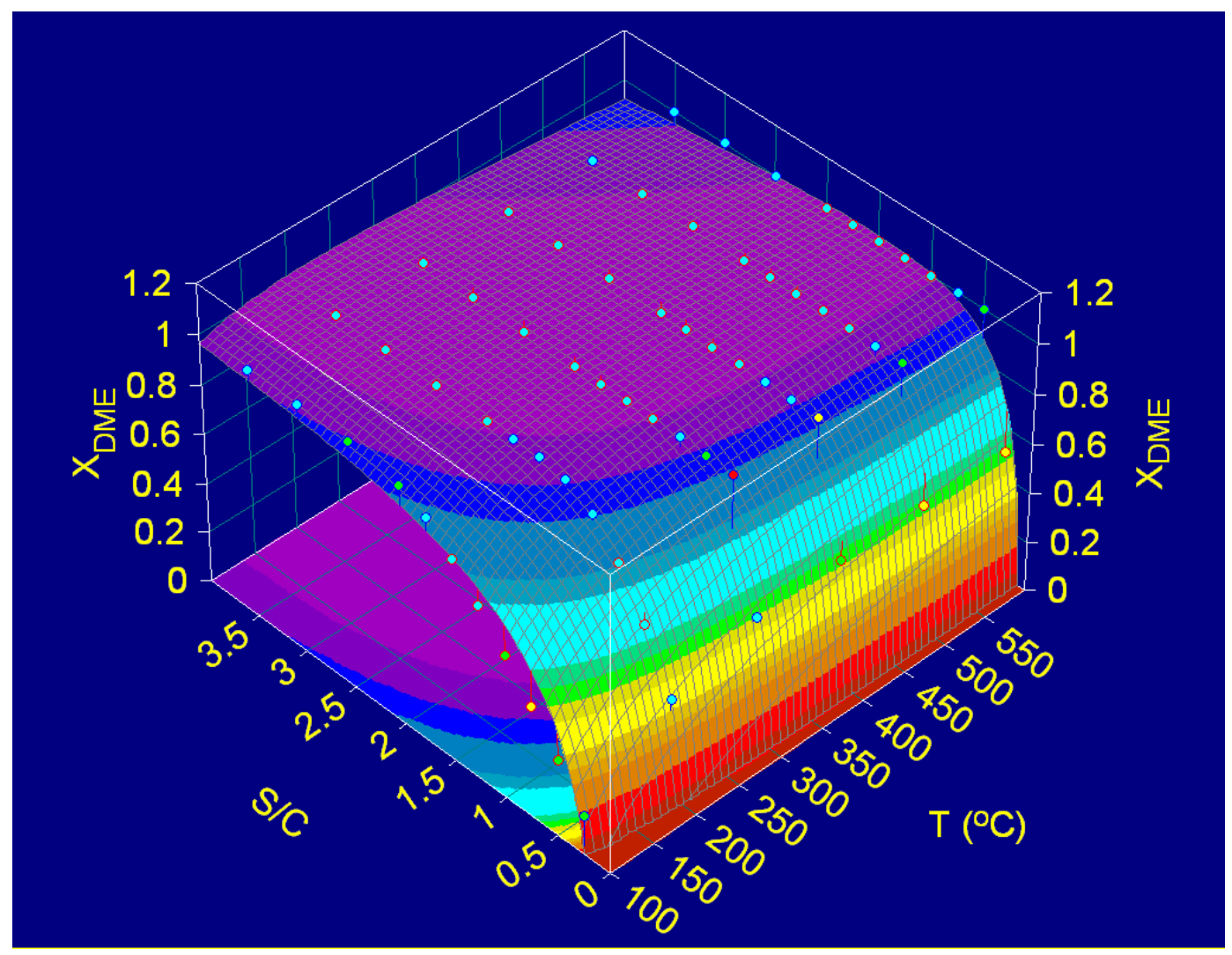

Figure 5. Plot of the thermodynamic equilibrium conversion of dimethyl ether as a function of steam-to-carbon ratio and temperature.

\subsection{DME-SR: Hydrogen Product Mole Fraction}

Figure 6 depicts the hydrogen mole fraction on a wet basis and dry basis for dimethyl ether steam reforming as a function of steam-to-carbon ratio and temperature. The theoretical maximum mole fraction of hydrogen for steam reforming of dimethyl ether is 0.75 . The maximum thermodynamic hydrogen effluent mole fraction modeled was 0.72 for a steam-to-carbon ratio equal to 1.5 and a temperature of $200^{\circ} \mathrm{C}$. The hydrogen production efficiency, defined as the effluent mole fraction of hydrogen divided by 0.75 , as a function of temperature and steam-to-carbon ratio can be seen Figure 6c. The decrease in the hydrogen mole fraction in Figure 6a and the hydrogen production efficiency in Figure $6 c$ are the result of steam dilution (i.e., S/C $>1.5$ ), reaction conversion (i.e., $\mathrm{S} / \mathrm{C}<1.0$ ) and carbon monoxide-water-gas-shift equilibrium. 


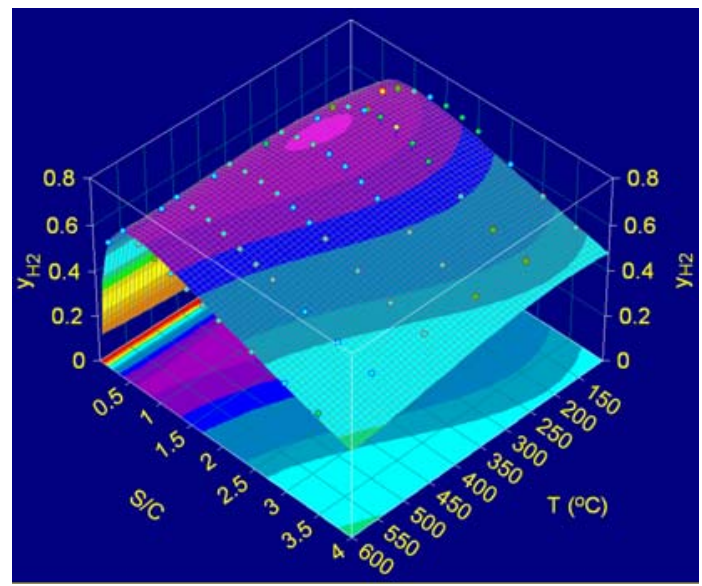

(a) Wet Basis

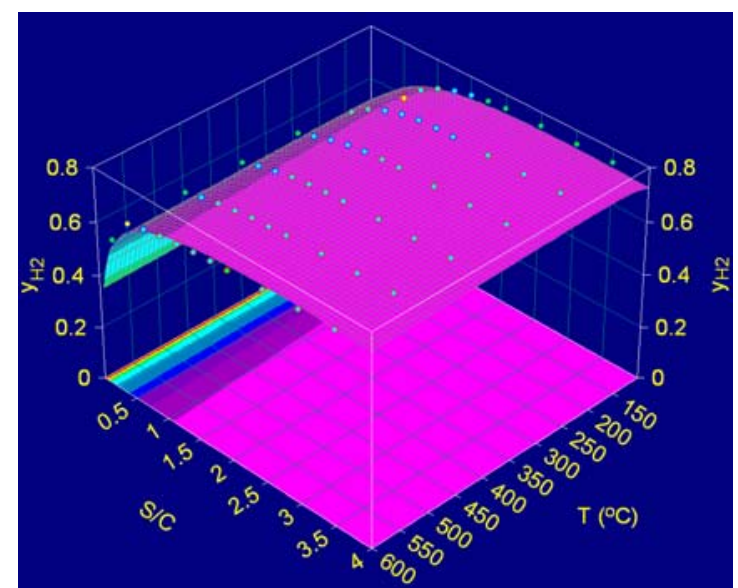

(b) Dry Basis

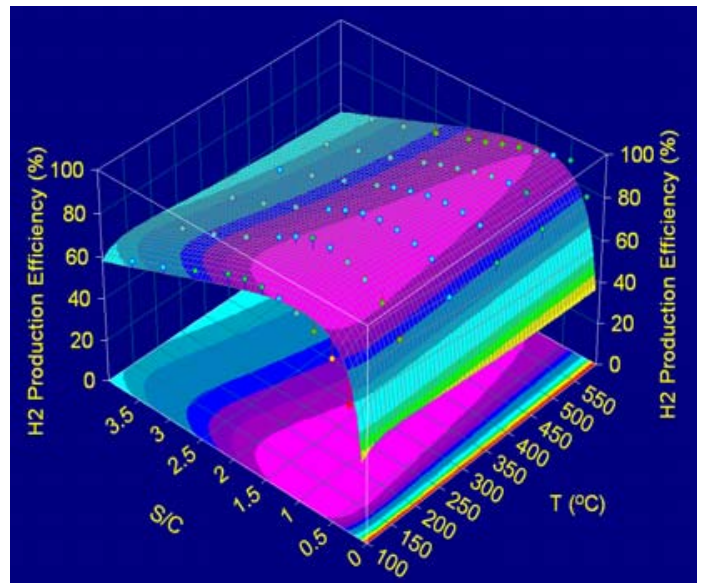

(c) Wet Basis

Figure 6. Plot of the thermodynamic equilibrium product mole fractions of hydrogen on a (a) wet basis and (b) dry basis as a function of steam-to-carbon ratio and temperature for dimethyl ether-steam reforming; (c) hydrogen production efficiency on a wet basis as a function of steam-to-carbon ratio and temperature.

For example, given a constant steam-to-carbon ratio the hydrogen mole fraction decreases monotonically as the temperature increases (Figures 6a)-primarily due to the water gas shift equilibrium. Accompanying a decrease in the hydrogen mole fraction is an increase in the carbon monoxide concentration. In contrast, under isothermal conditions, the hydrogen mole fraction on a wet basis is nonmonotonic. The hydrogen mole fraction increases with increasing steam-to-carbon ratio, reaching a maximum at a steam-to-carbon ratio equaling 1.5, then decreasing as the steam-to-carbon is further 
increased. The hydrogen mole fraction is more sensitive to the effects of dilution than with the effects of the water-gas-shift (WGS) equilibrium. Under isothermal conditions, the hydrogen mole fraction on a wet basis (Figure 6a) decreases faster due to steam dilution than the increase of hydrogen due to the water gas shift reaction (Figure 6b) as the steam-to-carbon ratio is increased.

Depending on the system under consideration, there are advantages to increasing the steam-to-carbon ratio. Advantages include carbon suppression for fuels such as diesel and gasoline, kinetic implications, and equilibrium implications. However, steamto-carbon ratios far greater than stoichiometric for systems with minimal/or no carbon formation, (i.e., MeOH-SR and DME-SR), minimal kinetic effects, and/or minimal equilibrium implications will impact the overall system efficiency of fuel processors. High steam-to-carbon ratios will have a large impact on the reactor volume (due to an increased water influent) and on the reactor heat duty (due to an increase in vaporization energy), than on the carbon monoxide effluent content, exemplified by the comparison of Figures $6 \mathrm{a}$ and $6 \mathrm{~b}$. This is especially true if an autothermal reactor operates at a considerably higher temperature than the high temperature shift (HTS) or low temperature shift (LTS) reactors. Water required for the HTS and LTS would most likely be introduced just prior to entering the HTS or LTS reactors. System integration and optimization is a nontrivial process that will conclusively determine the most efficient operating points for the system under consideration.

\subsection{DME-SR: Carbon Monoxide Product Mole Fraction}

Production of carbon monoxide during the steam reforming of dimethyl ether can be attributed to the water-gas shift reaction.

WGS: $\mathrm{H}_{2}+\mathrm{CO}_{2} \rightleftharpoons \mathrm{H}_{2} \mathrm{O}(\mathrm{v})+\mathrm{CO}$

$$
\Delta H_{r}^{o}=+41 \mathrm{~kJ} / \mathrm{mol}
$$

The carbon monoxide effluent concentration on a wet basis, depicted in Figure 7a, exhibits a narrow region of operating conditions, indicated by the small radius of curvature at the maximum. Due to the PEM fuel cell's intolerance to carbon monoxide, 
increasing carbon monoxide concentrations requires larger volumes of the HTS, LTS and PrOx reactors to effectively mitigate the carbon monoxide concentration.

Indicated in Figure 2, steam-to-carbon ratios of less than 1.0 are to be avoided because of the conversion constraint, thus eliminating the region of global maxima of carbon monoxide. The carbon monoxide mole fraction is observed to increase with increasing temperature for a given steam-to-carbon ratio and decrease with an increasing steam-to-carbon ratio at a given temperature. There is no mole change with the water-gas shift reaction; therefore, pressure effects are negligible. For a detailed view of the carbon monoxide concentrations as a function of temperature and steam-to-carbon ratio, refer to Appendix E.

Steam dilution effects are less pronounced (Figures 7a and 7b) with carbon monoxide than the effects of steam dilution on hydrogen (Figures 6a and 6b). However, for reasons discussed earlier, unnecessary dilution with steam should be avoided. 


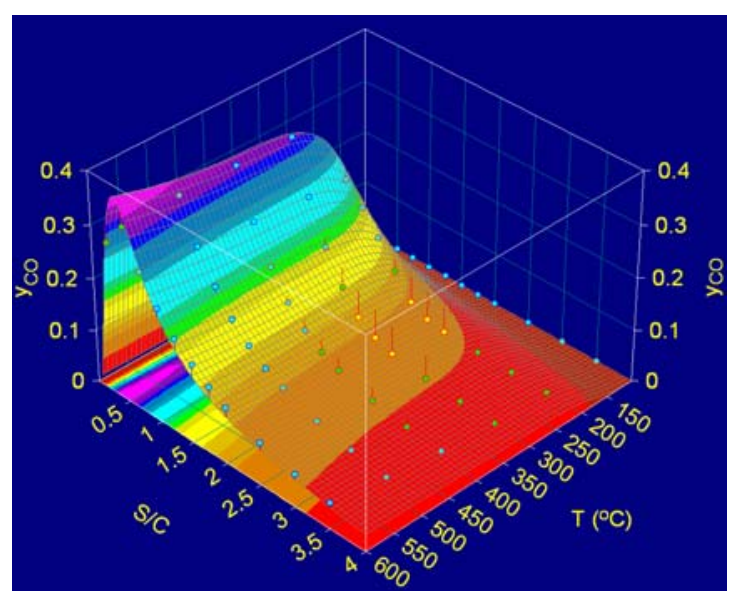

(a) Wet Basis

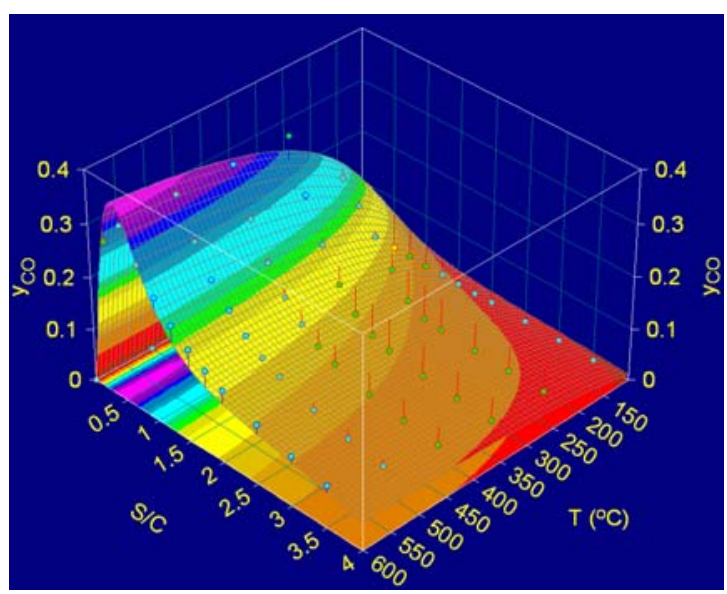

(b) Dry Basis

Figure 7. Plot of the thermodynamic equilibrium-product mole fractions of carbon monoxide on a (a) wet basis and (b) dry basis as a function of steam-to-carbon ratio and temperature for dimethyl ether steam reforming.

\section{0 DMe-SR: Optimal Processing for PeM Fuel Cells}

The optimal processing of any hydrocarbon fuel for producing hydrogen-rich fuel-cell feeds requires minimization of the carbon monoxide content to maximize the hydrogen content. This assumes that the carbon monoxide effluent is processed using $\mathrm{PrOx}$ reactors to a level that preserves the operability of the fuel cell, typically $\leq 10 \mathrm{ppm}$. Minimizing the carbon monoxide content and steam-to-carbon ratio from a steam 
reforming unit will reduce the downstream reactor volumes and proportionately decrease the startup energy, thus increasing the overall efficiency of the fuel processor.[4] The objective function used previously to determine the optimal operating conditions for autothermal processes was the difference in the effluent mole fractions of hydrogen and carbon monoxide on a dry basis. This, however, does not take into account the dilution effect. Therefore, to reduce unjustified steam dilution, the objective function was defined as follows,

$$
\begin{aligned}
& \left.d\left(y_{H_{2}}-y_{C O}\right)_{\text {wet basis }}=0 \text { (maximum }\right), \\
& \text { given } \\
& \qquad X_{D M E} \geq 99.5 \% .
\end{aligned}
$$

To help identify the operating conditions maximizing hydrogen while minimizing carbon monoxide, the difference in product mole fractions as a function of steam-tocarbon ratio and processing temperature are shown in Figure 8. The maximum of the objective function on a wet basis (Figure 8a) is seen to encompass small regions of temperature $\left(100-300^{\circ} \mathrm{C}\right)$ and steam-to-carbon ratios (1.0-2.5) (area magenta in color). If the objective function is plotted on a dry basis (Figure $8 \mathrm{~b}$ ), the suitable processing conditions resulting in a maximum difference in hydrogen and carbon monoxide product mole fractions expand to include temperatures up $450^{\circ} \mathrm{C}$ and steam-to-carbon ratios up to 4.0. The manifold of operating conditions increased from a wet basis to a dry basis because of the removal of water and its dilution effect. The optimal conditions for DME steam reforming, given the objective function, results in a global maximum at a steam-tocarbon ratio of 1.5 and processing temperature of $200^{\circ} \mathrm{C}$ (Figure 8a). 


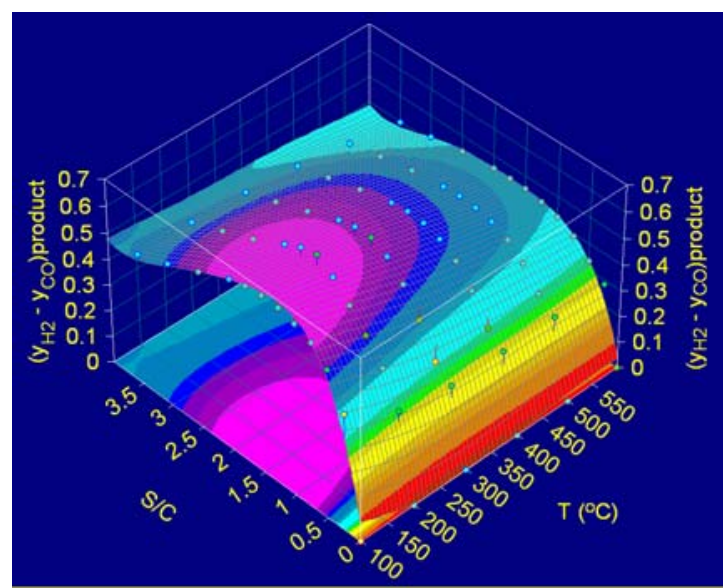

(a) Wet Basis

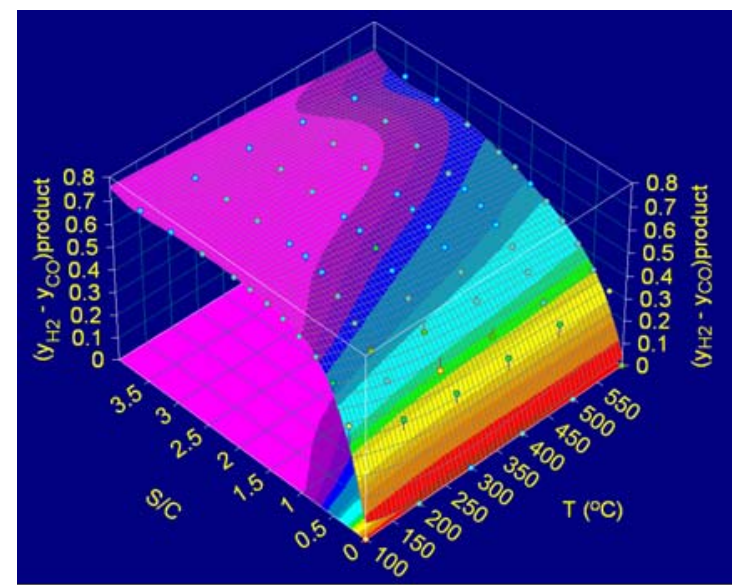

(b) Dry Basis

Figure 8. Plot of the difference in thermodynamic equilibrium product mole fractions of hydrogen and carbon monoxide on (a) wet basis and (b) dry basis as a function of steam-to-carbon ratio and temperature for dimethyl ether-steam reforming.

\subsection{DME-SR: Pressure Effects Under Optimal Processing Conditions}

The "optimal" steam-to-carbon ratio chosen to investigate the effects of pressure on dimethyl ether steam reforming; and to determine the thermodynamically viable products during the process of dimethyl ether steam reforming, was 2.5. A steam-tocarbon ratio of 2.5 was chosen to provide adequate water for CO shifting and PEM fuel cell membrane hydration. The effect of pressure on the fractional concentrations of dimethyl ether and hydrogen at a temperature of $100^{\circ} \mathrm{C}$ and a steam-to-carbon ratio of 2.5 can be seen in Figure 9. Increasing the pressure from $1 \mathrm{~atm}$ to $5 \mathrm{~atm}$ decreases the hydrogen production efficiency by 12 percent. The pressure effects are seen to shift the

equilibrium to the left; e.g., dimethyl ether steam reforming should be operated at low pressures to maintain a high degree of hydrogen production efficiency,

$$
\mathrm{CH}_{3} \mathrm{OCH}_{3}+3 \mathrm{H}_{2} \mathrm{O} \underset{\uparrow P}{\longrightarrow} 2 \mathrm{CO}_{2}+6 \mathrm{H}_{2} \text {. }
$$




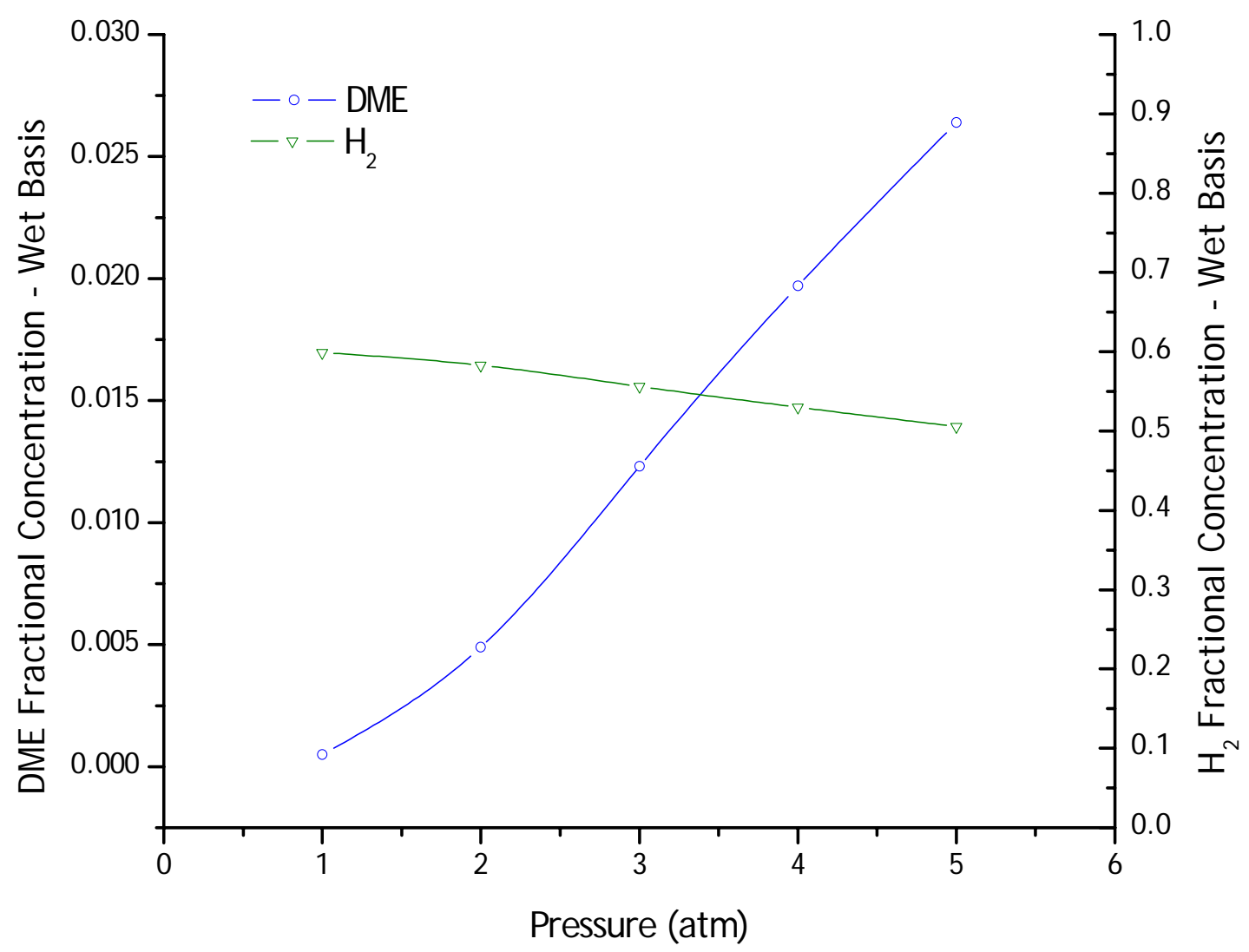

Figure 9. Pressure effects on DME-SR compositions of hydrogen and dimethyl ether processed at a temperature of $100^{\circ} \mathrm{C}$ and a steam-to-carbon ratio of 2.5 .

\subsection{DME-SR: Thermodynamically Feasible Products}

Based on the objective function, a steam-to-carbon ratio of 2.5 (Figure 8a) and a pressure of $1 \mathrm{~atm}$ (Figure 9) were chosen as the operating conditions for the determination of additional thermodynamically viable products. The thermodynamic equilibrium compositions were determined for operating temperatures ranging from 100 to $600^{\circ} \mathrm{C}$. The processing of dimethyl ether with steam at a steam-to-carbon ratio of 2.5 and a pressure of $1 \mathrm{~atm}$ will not affect the thermodynamically favored species in the expanded product set—only the concentrations, therefore the thermodynamically favored species will be observed regardless of the steam-to-carbon ratio employed. The order of the thermodynamically favored species in decreasing effluent mole fractions is tabulated in Table 2. The raw data are tabulated in Appendix F. 


\begin{tabular}{|c|c|c|}
\hline $\begin{array}{c}\text { Thermo } \\
\text { Case }\end{array}$ & $\begin{array}{c}\text { Most } \\
\text { Abundant }\end{array}$ & Species Excluded \\
\hline 1 & Methane & none \\
\hline 2 & Ethane & Methane \\
\hline 3 & $\begin{array}{l}\text { Isopropyl } \\
\text { Alcohol }\end{array}$ & Ethane + Methane \\
\hline 4 & Acetone & Isopropyl Alcohol +Ethane + Methane \\
\hline 5 & n-Propanol & Acetone + Isopropyl Alcohol +Ethane + Methane \\
\hline 6 & Ethylene & n-Propanol +Acetone + Isopropyl Alcohol +Ethane + Methane \\
\hline 7 & Ethanol & $\begin{array}{l}\text { Ethylene }+n \text {-Propanol }+ \text { Acetone }+ \text { Isopropyl Al cohol + Ethane } \\
+ \text { Methane }\end{array}$ \\
\hline 8 & Methyl-Ethyl Ether & $\begin{array}{l}\text { Ethanol +Ethylene +n-Propanol +Acetone + } \\
\text { Isopropyl Alcohol +Ethane + Methane }\end{array}$ \\
\hline 9 & Methanol & $\begin{array}{l}\text { Methyl-Ethyl Ether + Ethanol + Ethylene + n-Propanol + } \\
\text { Acetone +Isopropyl Alcohol +Ethane +Methane }\end{array}$ \\
\hline
\end{tabular}

Table 2. Thermodynamic cases for expanded dimethyl ether steam reforming product set with steam-to-carbon ratio of 2.5 and a pressure of $1 \mathrm{~atm}$.

Given the manifold of product species considered, methane (thermodynamic case 1) was the most abundant and methanol (thermodynamic case 10) the least abundant. The fractional concentrations of the most abundant species as a function of temperature are shown in Figure 10. Methane is favored over the entire temperature range investigated, while ethane is favored in the range of $100^{\circ} \mathrm{C}$ to $500^{\circ} \mathrm{C}$, when methane is not considered. For thermodynamic cases 3 through 8 the products approach zero fractional concentration as the temperature approaches $300^{\circ} \mathrm{C}$. Methanol, thermodynamic case 9, is favored but with a concentration of about $900 \mathrm{ppm}$ at a temperature of $100^{\circ} \mathrm{C}$. The absence of significant amounts of methanol is a direct consequence of the product basis set (specifically hydrogen, carbon dioxide and carbon monoxide). Formic acid, formaldehyde and acetylene were not observed to be favored thermodynamically. The results of Figure 10 on a dry basis are shown in Appendix G. The species in the 
expanded product set are thermodynamically viable at defined operating conditions as shown in Figure 10, however, they may or may not be observed experimentally depending upon others factors, such as the catalyst employed during the reforming reactions.

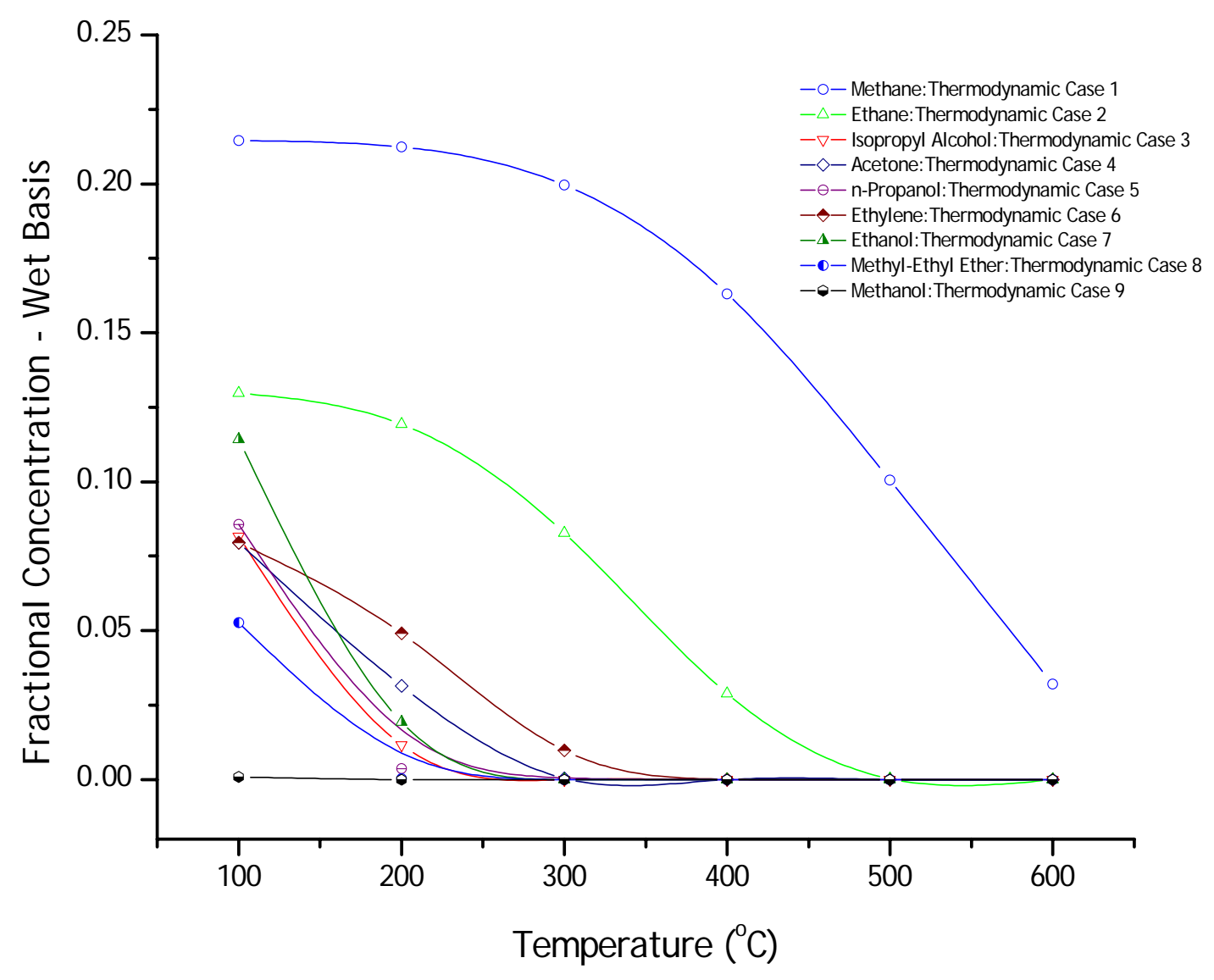

Figure 10. Compositions of the most abundant species for thermodynamic cases 1-9 as a function of temperature at a steam-to-carbon ratio of 2.5 and a pressure of $1 \mathrm{~atm}$. 


\subsection{Results: Dimethyl Ether Hydrolysis}

\subsection{DME Hydrolysis: Thermodynamic Conversion}

To examine the equilibrium conversion of dimethyl ether to methanol, dimethyl ether hydrolysis equilibrium was modeled. The only product species considered were dimethyl ether, methanol and water. The conversion of dimethyl ether through hydrolysis to methanol as a function of steam-to-carbon ratio and temperature is depicted in Figure 11. The conversion of dimethyl ether to methanol is thermodynamically limited. Dimethyl ether conversion increases monotonically for a given steam-to-carbon ratio or for a given temperature. Increasing the steam-to-carbon ratio or temperature drives the DME hydrolysis reaction to the right, thus increasing the conversion of dimethyl ether and the amount of methanol produced.

DME Hydrolysis : $\mathrm{CH}_{3} \mathrm{OCH}_{3}+\mathrm{H}_{2} \mathrm{O} \underset{\text { Catalyst }}{\stackrel{\text { Acid }}{\rightleftarrows}} 2 \mathrm{CH}_{3} \mathrm{OH} \quad \Delta \mathrm{H}_{r}^{0}=+37 \mathrm{~kJ} / \mathrm{mol}$.

Consequently, increasing both the processing temperature and steam-to-carbon ratio will result in a maximum increase in dimethyl ether conversion to methanol. Tabulated data for the hydrolysis of dimethyl ether is in Appendix $\mathrm{H}$.

For a stoichiometric steam to carbon ratio; e.g., 0.5, the highest conversion of dimethyl ether that can be reached in the temperature range investigated is $25 \%$ at $600^{\circ} \mathrm{C}$. Implementing a steam-to-carbon ratio of 2.0, results in a dimethyl ether conversion of $26 \%$ at $300^{\circ} \mathrm{C}$ and a maximum dimethyl ether conversion of $45 \%$ at $600^{\circ} \mathrm{C}$. The maximum conversion of dimethyl ether occurs at the extrema $\left(\mathrm{T}=600^{\circ} \mathrm{C}\right.$ and $\left.\mathrm{S} / \mathrm{C}=5.0\right)$ correlating to a value of $62 \%$. 


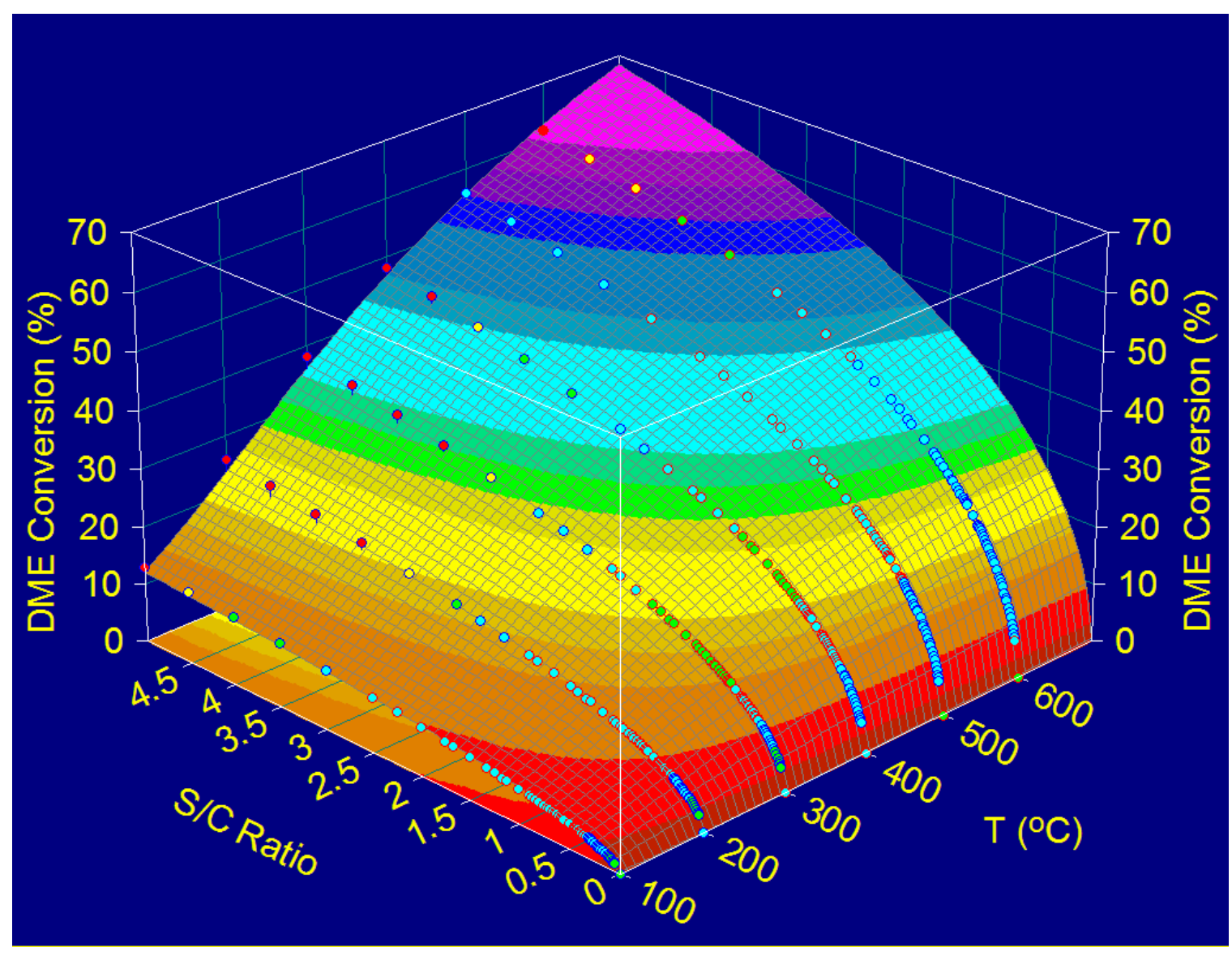

Figure 11. DME equilibrium conversion as a function of temperature and steam-tocarbon ratio for the hydrolysis of dimethyl ether.

The equilibrium methanol composition for the dimethyl ether hydrolysis reaction as a function of steam-to-carbon ratio and temperature is illustrated in Figure 12. At a given steam-to-carbon ratio, the methanol mole fraction on a wet basis (Figure 12a) is monotonic with increasing temperature. Operating isothermally, the methanol composition is non-monotonic with increasing steam-to-carbon ratio. The nonmonotonic nature of the methanol effluent mole fraction as a function of the steam-tocarbon ratio is a direct consequence of steam dilution. The maximum methanol effluent mole fraction on a wet basis occurs at a steam-to-carbon ratio of 1.0 and a temperature of $600^{\circ} \mathrm{C}$ with a value equaling $23 \%$.

The methanol composition trends with temperature and steam-to-carbon ratio if the effects of steam dilution are removed (Figure 12b)—analogous to the conversion of dimethyl ether (Figure 11). Increasing the steam-to-carbon ratio introduces water into the 
system faster than the increase in the equilibrium composition of methanol; evidenced by comparing of Figures 12a and 12b.

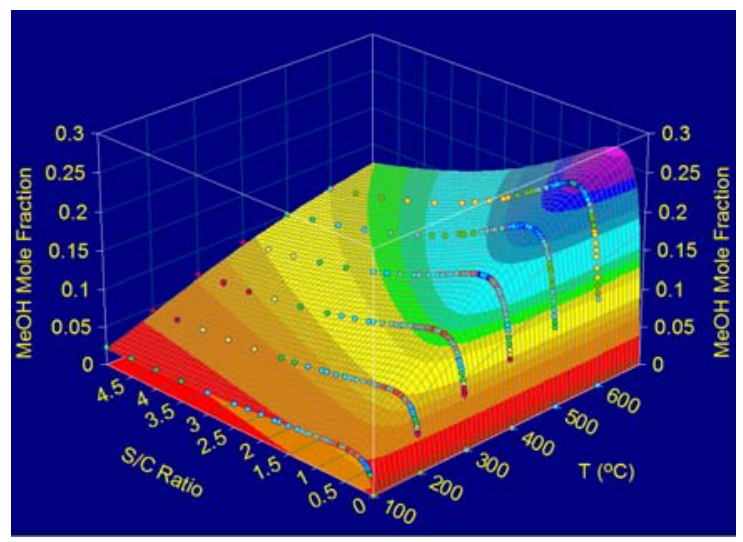

(a) Wet Basis

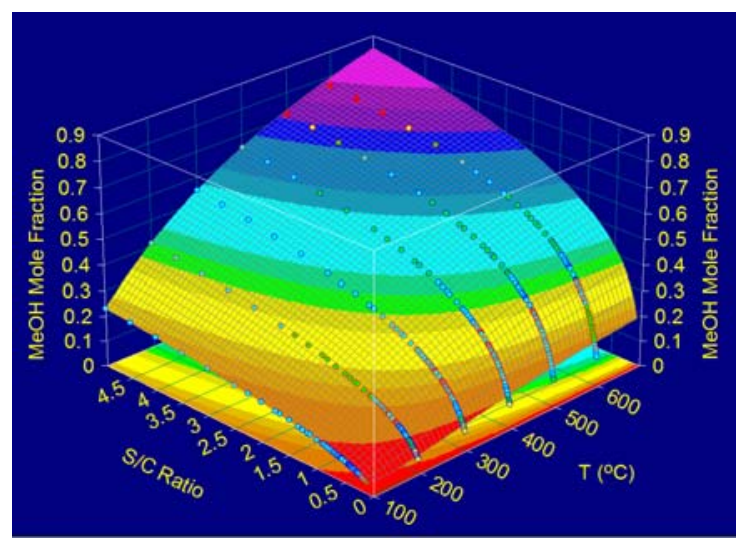

(b) Dry Basis

Figure 12. Effluent equilibrium compositions of methanol on a (a) wet basis and (b) dry basis as a function of temperature and steam-to-carbon ratio for the hydrolysis of dimethyl ether.

\subsection{DME Hydrolysis: Optimal Processing Conditions}

If production of hydrogen from dimethyl ether proceeds via hydrolysis to methanol, followed by methanol steam reforming, then the minimum steam-to-carbon ratio required is 1.5 (stoichiometric quantities of steam and dimethyl ether)—or equivalently:

$$
\mathrm{CH}_{3} \mathrm{OCH}_{3}+3 \mathrm{H}_{2} \mathrm{O} \underset{\text { Catalyst }}{\stackrel{\text { Acid }}{\rightleftharpoons}} 2 \mathrm{CH}_{3} \mathrm{OH}+2 \mathrm{H}_{2} \mathrm{O} \stackrel{\mathrm{Cu} / \mathrm{Zn}}{\rightleftharpoons} 6 \mathrm{H}_{2}+2 \mathrm{CO}_{2} \text {. }
$$

The effect of water dilution may or may not be justified; consequently, the system under consideration will ultimately dictate the proper conditions of operation. The kinetics of the system may be observed to be a strong function of water, thus lending justification for implementing a steam-to-carbon ratio greater than 1.5. The rate enhancement may be such that excess steam will result in a net reduction in reactor volume and therefore start-up energy. The overall system design, operating conditions, catalysts employed and application will dictate the proper amounts of water that lead to the most efficient process. 


\subsection{CONCLUSIONS}

Thermodynamically, dimethyl ether is a viable fuel for producing hydrogen-rich fuel-cell feeds. The products of hydrogen, carbon monoxide and carbon dioxide are thermodynamically favored over a wide range of steam-to-carbon ratios and temperatures. The optimal thermodynamic processing conditions for dimethyl ether steam reforming occur at a steam-to-carbon ratio of 1.5 , a temperature of $200^{\circ} \mathrm{C}$ and a pressure of $1 \mathrm{~atm}$. Increasing the processing pressure shifts the equilibrium to the reactants (dimethyl ether and water)-hence, the processing pressures should be maintained at, or near, ambient pressure. If the catalysts employed in practice are not selective to hydrogen, carbon monoxide and carbon dioxide, then additional thermodynamically favored products may be observed; such as, methane, ethane, and other hydrocarbons and alcohols.

The equilibrium calculations considering the hydrolysis of dimethyl ether to methanol indicate that the conversion of dimethyl ether to methanol is thermodynamically limited (other product species not considered). A maximum dimethyl ether conversion of $62 \%$ occurred at a steam-to-carbon ratio of 5.0 and a temperature of $600^{\circ} \mathrm{C}$. 


\subsection{ACKNOWLEDGEMENTS}

This work was partially supported by the US Department of Energy, Hydrogen, Fuel Cells and Infrastructure Program. The authors gratefully acknowledge Michael A. Inbody for his comments and suggestions 


\subsection{RefERENCE LIST}

(1) Fleisch T. Prospects for DME as a multi-purpose fuel. IBC Gas to Liquids Conference, Milan, Italy (2002).

(2) Muller JT, Urban PM, Holderich WF, Colbow KM, Zhang J, Wilkinson DP. Electro-oxidation of dimethyl ether in a polymer-electrolyte-membrane fuel cell. Journal of the Electrochemical Society 2000; 147(11):4058-4060.

(3) Murray EP, Harris SJ, Jen HW. Solid oxide fuel cells utilizing dimethyl ether fuel. Journal of the Electrochemical Society 2002; 149(9):A1127-A1131.

(4) Semelsberger TA, Brown LF, Borup RL, Inbody MA. Equilibrium products from autothermal processes for generating hydrogen-rich fuel-cell feeds. International Journal of Hydrogen Energy 2004; 29:1047-1064.

(5) Sobyanin VA, Cavallaro S, Freni S. Dimethyl ether steam reforming to feed molten carbonate fuel cells (MCFCs). Energy \& Fuels 2000; 14(6):1139-1142.

(6) Wang SZ, Ishihara T, Takita Y. Dimethyl ether fueled intermediate temperature SOFC using LaGaO3-based perovskite electrolytes. Electrochemical and Solid State Letters 2002; 5(8):A177-A180.

(7) Yomada, Koji, Asazawa, Koichiro, Tanaka, Hirohisa. Daihatsu Motor Co. L, editor. Dimethyl ether reforming catalyst. patent 6,605,559 (2003).

(8) Bhattacharyya, Alakananda, Basu, Arunabha. Amoco Corporation, editor. Process for hydroshifting dimethyl ether. patent 5,498,370 (1996).

(9) Semelsberger TA, Borup RL. Hydrogen production form the steam reforming of dimethyl ether and methanol. 205th Electrochemical Society Meeting, San Antonio, Texas (2004).

(10) Keil FJ. Methanol-to-hydrocarbons: process technology. Microporous and Mesoporous Materials 1999; 29(1-2):49-66.

(11) Shikada T, Ohno Y, Ogawa T, Ono M, Mizuguchi M, Tomura K, Fujimoto K. Direct synthesis of dimethyl ether form synthesis gas. Studies in Surface Science and Catalysis 1998; 119:515-520.

(12) Stocker M. Methanol-to-hydrocarbons: catalytic materials and their behavior. Microporous and Mesoporous Materials 1999; 29(1-2):3-48.

(13) Zheng XM, Fei JH, Hou ZY. Catalysis for one-step synthesis of dimethyl ether from hydrogenation of CO. Chinese Journal of Chemistry 2001; 19(1):67-72.

(14) Haggin J. Dimethyl ether from syngas in one-step. Chemical \& Engineering News 1991; 69(29):20-21. 
(15) Kim HJ, Jung H, Lee KY. Effect of water on liquid phase DME synthesis from syngas over hybrid catalysts composed of $\mathrm{Cu} / \mathrm{ZnO} / \mathrm{Al} 2 \mathrm{O} 3$ and gamma-Al2O3. Korean Journal of Chemical Engineering 2001; 18(6):838-841.

(16) Peng XD, Wang AW, Toseland BA, Tijm PJA. Single-step syngas-to-dimethyl ether processes for optimal productivity; minimal emissions; and natural gasderived syngas. Industrial \& Engineering Chemistry Research 1999; 38(11):43814388.

(17) Qi GX, Fei JH, Zheng XM, Hou ZY. DME synthesis from CO/H-2 over Cu$\mathrm{Mn} / \mathrm{gamma}-\mathrm{Al} 2 \mathrm{O} 3$ catalyst. Reaction Kinetics and Catalysis Letters 2001; 73(2):245-256.

(18) Shen WJ, Jun KW, Choi HS, Lee KW. Thermodynamic investigation of methanol and dimethyl ether synthesis from CO2 hydrogenation. Korean Journal of Chemical Engineering 2000; 17(2):210-216.

(19) Shikada T, Ohno Y, Ogawa T, Ono M, Mizuguchi M, Tomura K, Fujimoto K. Synthesis of dimethyl ether from natural gas via synthesis gas. Kinetics and Catalysis 1999; 40(3):395-400.

(20) Wang ZL, Diao J, Wang JF, Jin Y, Peng XD. Study on synergy effect in dimethyl ether synthesis from syngas. Chinese Journal of Chemical Engineering 2001; 9(4):412-416.

(21) Xu M, Lunsford JH, Goodman DW, Bhattacharyya A. Synthesis of dimethyl ether (DME) from methanol over solid-acid catalysts. Applied Catalysis A: General:289-301.

(22) Elam N. The Bio-DME Project (2002).

(23) Fleisch TH, Basu A, Gradassi MJ, Masin JG. Dimethyl ether: A fuel for the 21st century. Studies in Surface Science and Catalysis 1997; 107:117-125.

(24) Gill DW, Ofner H. DME as an automotive fuel. 9th IEA Workshop (2001).

(25) Hansen JB, Mikkelsen S. DME as a transportation fuel. (2001).

(26) Huang ZH, Wang HW, Chen HY, Zhou LB, Jiang DM. Study of combustion characteristics of a compression ignition engine fuelled with dimethyl ether. Proceedings of the Institution of Mechanical Engineers Part D-Journal of Automobile Engineering 1999; 213(D6):647-652.

(27) International Energy Agency. DME Newsletter 3: "Dimethyl ether as automotive fuel". (1999).

(28) International Energy Agency. DME Newsletter 4: "Dimethyl ether as automotive fuel". (2000). 
(29) Roy MM, Tsunemoto H, Ishitani H. Effect of MTBE and DIME on odorous emissions in a DI diesel engine. International Journal Series B-Fluids and Thermal Engineering 2000; 43(3):511-517.

(30) Wang HW, Huang ZH, Zhou LB, Jiang DM, Yang ZL. Investigation on emission characteristics of a compression ignition engine with oxygenated fuels and exhaust gas recirculation. Proceedings of the Institution of Mechanical Engineers Part D-Journal of Automobile Engineering 2000; 214(D5):503-508.

(31) Wang HW, Zhou LB, Jiang DM, Huang ZH. Study on the performance and emissions of a compression ignition engine fuelled with dimethyl ether. Proceedings of the Institution of Mechanical Engineers Part D-Journal of Automobile Engineering 2000; 214(D1):101-106.

(32) Engine performance and emissions from fuel blends of dimethyl ether (DME) and diesel fuel. 02 Mar 11; American Institute of Chemical Engineers, (2002).

(33) Chen ZL, Konno M, Kajitani S. Performance and emissions of DI compression ignition engines fueled with dimethyl ether (Performance and emissions in retrofitted engines). International Journal Series B-Fluids and Thermal Engineering 2000; 43(1):82-88.

(34) Rouhi AM. Amoco; Halder-Topsoe develop dimethyl ether as alternative diesel fuel. Chemical \& Engineering News 1995; 73(22):37-39.

(35) Sun M, Yu L, Sun C, Song Y, Sun J. Application of dimethyl ether and development of its downstream products. General Review 20[11] (2003).

(36) Ohno Y, Inoue N, Ogawa T, Ono M, Shikada T, Hayashi H. Slurry phase synthesis and utilization of dimethyl ether. NKK Technical Review (2001).

(37) Perry's Chemical Engineers' Handbook. New York: McGraw-Hill, (1999).

(38) Bandiera J, Naccache C. Kinetics of methanol dehydration on dealuminated Hmordenite: model with acid and basic acid-centers. Applied Catalysis 1991; 69(1):139-148.

(39) Freeman D, Wells RPK, Hutchings GJ. Conversion of methanol to hydrocarbons over Ga2O3/H-ZSM-5 and Ga2O3/WO3 catalysts. Journal of Catalysis 2002; 205(2):358-365.

(40) Hutchings GJ, Watson GW, Willock DJ. Methanol conversion to hydrocarbons over zeolite catalysts: comments on the reaction mechanism for the formation of the first carbon-carbon bond. Microporous and Mesoporous Materials 1999; 29(12):67-77. 
(41) Hytha M, Stich I, Gale JD, Terakura K, Payne MC. Thermodynamics of catalytic formation of dimethyl ether from methanol in acidic zeolites. Chemistry-A European Journal 2001; 7(12):2521-2527.

(42) Klier K, Beretta A, Sun Q, Feeley OC, Herman RG. Catalytic synthesis of methanol; higher alcohols and ethers. Catalysis Today 1997; 36(1):3-14.

(43) Park TY, Froment GF. Kinetic modeling of the methanol to olefins process. 1. Model formulation. Industrial \& Engineering Chemistry Research 2001; 40(20):4172-4186.

(44) Park TY, Froment GF. Kinetic modeling of the methanol to olefins process. 2. Experimental results ; model discrimination ; and parameter estimation. Industrial \& Engineering Chemistry Research 2001; 40(20):4187-4196.

(45) Xu MT, Goodman DW, Bhattacharyya A. Catalytic dehydration of methanol to dimethyl ether (DME) over Pd/Cab-O-Sil catalysts. Applied Catalysis A-General 1997; 149(2):303-309. 


\section{Appendix A}

\section{Compilation of Thermodynamic Data for DME-SR on a Wet Basis}

Thermodynamic Results for Dimethyl Ether Steam Reforming on a Wet Basis for S/C $=0.00-1.50$

\begin{tabular}{|c|c|c|c|c|c|c|c|c|c|}
\hline \multicolumn{2}{|c|}{ Operating Conditions } & \multirow{2}{*}{$\begin{array}{l}\text { DME Fractional } \\
\text { Conversion }\end{array}$} & \multicolumn{5}{|c|}{ Effluent Mole Fractions } & \multirow{2}{*}{$\begin{array}{c}\text { Mole Fraction } \\
\text { Difference } \\
\left(\mathrm{y}_{\mathrm{H} 2}-\mathrm{y}_{\mathrm{CO}}\right)\end{array}$} & \multirow{2}{*}{$\begin{array}{c}\mathrm{H}_{2} \\
\text { Production } \\
\text { Efficiency }\end{array}$} \\
\hline S/C & Temp $\left({ }^{\circ} \mathrm{C}\right)$ & & $\mathrm{CH}_{3} \mathrm{OCH}_{3}$ & $\mathrm{H}_{2} \mathrm{O}$ & $\mathrm{H}_{2}$ & $\mathrm{CO}$ & $\mathrm{CO}_{2}$ & & \\
\hline \multirow{6}{*}{0.00} & 100 & 0.0000 & 1.0000 & 0.0000 & 0.0000 & 0.0000 & 0.0000 & 0.0000 & 0.00 \\
\hline & 200 & 0.0000 & 1.0000 & 0.0000 & 0.0000 & 0.0000 & 0.0000 & 0.0000 & 0.00 \\
\hline & 300 & 0.0000 & 1.0000 & 0.0000 & 0.0000 & 0.0000 & 0.0000 & 0.0000 & 0.00 \\
\hline & 400 & 0.0000 & 1.0000 & 0.0000 & 0.0000 & 0.0000 & 0.0000 & 0.0000 & 0.00 \\
\hline & 500 & 0.0000 & 1.0000 & 0.0000 & 0.0000 & 0.0000 & 0.0000 & 0.0000 & 0.00 \\
\hline & 600 & 0.0000 & 0.9998 & 0.0000 & 0.0001 & 0.0000 & 0.0000 & 0.0001 & 0.01 \\
\hline \multirow{6}{*}{0.25} & 100 & 0.1609 & 0.3915 & 0.0099 & 0.4485 & 0.0018 & 0.1483 & 0.4467 & 59.80 \\
\hline & 200 & 0.3978 & 0.1948 & 0.0003 & 0.5475 & 0.2247 & 0.0327 & 0.3228 & 73.00 \\
\hline & 300 & 0.5000 & 0.1429 & 0.0000 & 0.5714 & 0.2857 & 0.0000 & 0.2857 & 76.19 \\
\hline & 400 & 0.5000 & 0.1429 & 0.0000 & 0.5714 & 0.2857 & 0.0000 & 0.2857 & 76.19 \\
\hline & 500 & 0.5000 & 0.1429 & 0.0000 & 0.5714 & 0.2857 & 0.0000 & 0.2857 & 76.19 \\
\hline & 600 & 0.5000 & 0.1429 & 0.0000 & 0.5714 & 0.2857 & 0.0000 & 0.2857 & 76.19 \\
\hline \multirow{6}{*}{0.50} & 100 & 0.3097 & 0.2132 & 0.0232 & 0.5724 & 0.0013 & 0.1900 & 0.5712 & 76.32 \\
\hline & 200 & 0.6272 & 0.0827 & 0.0011 & 0.6380 & 0.1966 & 0.0816 & 0.4414 & 85.06 \\
\hline & 300 & 0.9961 & 0.0007 & 0.0000 & 0.6664 & 0.3323 & 0.0006 & 0.3341 & 88.86 \\
\hline & 400 & 0.9999 & 0.0000 & 0.0000 & 0.6667 & 0.3333 & 0.0000 & 0.3333 & 88.89 \\
\hline & 500 & 1.0000 & 0.0000 & 0.0000 & 0.6667 & 0.3333 & 0.0000 & 0.3333 & 88.89 \\
\hline & 600 & 1.0000 & 0.0000 & 0.0000 & 0.6667 & 0.3333 & 0.0000 & 0.3333 & 88.89 \\
\hline \multirow{6}{*}{0.75} & 100 & 0.4510 & 0.1276 & 0.0352 & 0.6277 & 0.0010 & 0.2086 & 0.6267 & 83.69 \\
\hline & 200 & 0.7969 & 0.0357 & 0.0022 & 0.6819 & 0.1588 & 0.1214 & 0.5231 & 90.92 \\
\hline & 300 & 1.0000 & 0.0000 & 0.0051 & 0.6872 & 0.2359 & 0.0718 & 0.4513 & 91.63 \\
\hline & 400 & 1.0000 & 0.0000 & 0.0142 & 0.6782 & 0.2449 & 0.0628 & 0.4332 & 90.42 \\
\hline & 500 & 1.0000 & 0.0000 & 0.0258 & 0.6665 & 0.2566 & 0.0511 & 0.4099 & 88.87 \\
\hline & 600 & 1.0000 & 0.0000 & 0.0367 & 0.6556 & 0.2675 & 0.0402 & 0.3881 & 87.41 \\
\hline \multirow{6}{*}{1.00} & 100 & 0.5850 & 0.0777 & 0.0467 & 0.6565 & 0.0008 & 0.2183 & 0.6556 & 87.53 \\
\hline & 200 & 0.9179 & 0.0123 & 0.0040 & 0.7085 & 0.1170 & 0.1582 & 0.5915 & 94.46 \\
\hline & 300 & 1.0000 & 0.0000 & 0.0140 & 0.7002 & 0.1569 & 0.1288 & 0.5433 & 93.37 \\
\hline & 400 & 1.0000 & 0.0000 & 0.0341 & 0.6802 & 0.1769 & 0.1088 & 0.5033 & 90.70 \\
\hline & 500 & 1.0000 & 0.0000 & 0.0559 & 0.6583 & 0.1988 & 0.0869 & 0.4596 & 87.78 \\
\hline & 600 & 1.0000 & 0.0000 & 0.0747 & 0.6396 & 0.2176 & 0.0681 & 0.4220 & 85.27 \\
\hline \multirow{6}{*}{1.25} & 100 & 0.7098 & 0.0458 & 0.0591 & 0.6712 & 0.0007 & 0.2233 & 0.6705 & 89.49 \\
\hline & 200 & 0.9836 & 0.0022 & 0.0086 & 0.7246 & 0.0693 & 0.1954 & 0.6553 & 96.61 \\
\hline & 300 & 1.0000 & 0.0000 & 0.0301 & 0.7032 & 0.0968 & 0.1699 & 0.6064 & 93.76 \\
\hline & 400 & 1.0000 & 0.0000 & 0.0603 & 0.6730 & 0.1270 & 0.1397 & 0.5461 & 89.74 \\
\hline & 500 & 1.0000 & 0.0000 & 0.0891 & 0.6442 & 0.1558 & 0.1109 & 0.4884 & 85.90 \\
\hline & 600 & 1.0000 & 0.0000 & 0.1127 & 0.6206 & 0.1794 & 0.0873 & 0.4412 & 82.75 \\
\hline \multirow{6}{*}{1.50} & 100 & 0.8212 & 0.0245 & 0.0742 & 0.6758 & 0.0006 & 0.2249 & 0.6753 & 90.11 \\
\hline & 200 & 0.9992 & 0.0001 & 0.0263 & 0.7237 & 0.0260 & 0.2239 & 0.6977 & 96.49 \\
\hline & 300 & 1.0000 & 0.0000 & 0.0571 & 0.6929 & 0.0571 & 0.1929 & 0.6357 & 92.38 \\
\hline & 400 & 1.0000 & 0.0000 & 0.0920 & 0.6580 & 0.0920 & 0.1580 & 0.5660 & 87.73 \\
\hline & 500 & 1.0000 & 0.0000 & 0.1239 & 0.6261 & 0.1239 & 0.1261 & 0.5022 & 83.48 \\
\hline & 600 & 1.0000 & 0.0000 & 0.1498 & 0.6002 & 0.1498 & 0.1002 & 0.4504 & 80.03 \\
\hline
\end{tabular}




\section{Appendix A (Continued)}

Thermodynamic Results for Dimethyl Ether Steam Reforming on a Wet Basis for S/C $=1.75-4.00$

\begin{tabular}{|c|c|c|c|c|c|c|c|c|c|}
\hline \multicolumn{2}{|c|}{ Operating Conditions } & \multirow{2}{*}{$\begin{array}{c}\text { DME Fractional } \\
\text { Conversion }\end{array}$} & \multicolumn{5}{|c|}{ Effluent Mole Fractions } & \multirow{2}{*}{$\begin{array}{c}\text { Mole Fraction } \\
\text { Difference } \\
\left(\mathrm{y}_{\mathrm{H} 2}-\mathrm{y}_{\mathrm{cO}}\right)\end{array}$} & \multirow{2}{*}{$\begin{array}{c}\quad \mathrm{H}_{2} \\
\text { Production } \\
\text { Efficiency }\end{array}$} \\
\hline $\mathrm{s} / \mathrm{C}$ & Temp $\left({ }^{\circ} \mathrm{C}\right)$ & & $\mathrm{CH}_{3} \mathrm{OCH}_{3}$ & $\mathrm{H}_{2} \mathrm{O}$ & $\mathrm{H}_{2}$ & $\mathrm{CO}$ & $\mathrm{CO}_{2}$ & & \\
\hline \multirow{6}{*}{1.75} & 100 & 0.9104 & 0.0110 & 0.0949 & 0.6705 & 0.0004 & 0.2232 & 0.6701 & 89.40 \\
\hline & 200 & 1.0000 & 0.0000 & 0.0685 & 0.6962 & 0.0097 & 0.2256 & 0.6865 & 92.83 \\
\hline & 300 & 1.0000 & 0.0000 & 0.0938 & 0.6709 & 0.0350 & 0.2003 & 0.6359 & 89.45 \\
\hline & 400 & 1.0000 & 0.0000 & 0.1271 & 0.6376 & 0.0683 & 0.1670 & 0.5694 & 85.02 \\
\hline & 500 & 1.0000 & 0.0000 & 0.1589 & 0.6058 & 0.1001 & 0.1352 & 0.5056 & 80.77 \\
\hline & 600 & 1.0000 & 0.0000 & 0.1855 & 0.5792 & 0.1266 & 0.1087 & 0.4526 & 77.23 \\
\hline \multirow{6}{*}{2.00} & 100 & 0.9652 & 0.0039 & 0.1249 & 0.6533 & 0.0003 & 0.2176 & 0.6530 & 87.10 \\
\hline & 200 & 1.0000 & 0.0000 & 0.1163 & 0.6615 & 0.0052 & 0.2170 & 0.6562 & 88.19 \\
\hline & 300 & 1.0000 & 0.0000 & 0.1344 & 0.6434 & 0.0233 & 0.1989 & 0.6201 & 85.79 \\
\hline & 400 & 1.0000 & 0.0000 & 0.1633 & 0.6145 & 0.0521 & 0.1701 & 0.5624 & 81.94 \\
\hline & 500 & 1.0000 & 0.0000 & 0.1934 & 0.5844 & 0.0822 & 0.1400 & 0.5022 & 77.92 \\
\hline & 600 & 1.0000 & 0.0000 & 0.2194 & 0.5584 & 0.1083 & 0.1140 & 0.4501 & 74.45 \\
\hline \multirow{6}{*}{2.50} & 100 & 0.9954 & 0.0005 & 0.2019 & 0.5982 & 0.0002 & 0.1993 & 0.5980 & 79.76 \\
\hline & 200 & 1.0000 & 0.0000 & 0.2025 & 0.5975 & 0.0025 & 0.1975 & 0.5951 & 79.67 \\
\hline & 300 & 1.0000 & 0.0000 & 0.2126 & 0.5874 & 0.0126 & 0.1874 & 0.5747 & 78.31 \\
\hline & 400 & 1.0000 & 0.0000 & 0.2331 & 0.5669 & 0.0331 & 0.1669 & 0.5338 & 75.59 \\
\hline & 500 & 1.0000 & 0.0000 & 0.2580 & 0.5420 & 0.0580 & 0.1420 & 0.4840 & 72.27 \\
\hline & 600 & 1.0000 & 0.0000 & 0.2815 & 0.5185 & 0.0815 & 0.1185 & 0.4370 & 69.14 \\
\hline \multirow{6}{*}{3.00} & 100 & 0.9990 & 0.0001 & 0.2732 & 0.5450 & 0.0001 & 0.1816 & 0.5449 & 72.67 \\
\hline & 200 & 1.0000 & 0.0000 & 0.2742 & 0.5439 & 0.0015 & 0.1803 & 0.5424 & 72.53 \\
\hline & 300 & 1.0000 & 0.0000 & 0.2809 & 0.5373 & 0.0081 & 0.1737 & 0.5292 & 71.64 \\
\hline & 400 & 1.0000 & 0.0000 & 0.2956 & 0.5226 & 0.0229 & 0.1589 & 0.4997 & 69.67 \\
\hline & 500 & 1.0000 & 0.0000 & 0.3157 & 0.5025 & 0.0430 & 0.1389 & 0.4595 & 67.00 \\
\hline & 600 & 1.0000 & 0.0000 & 0.3361 & 0.4821 & 0.0634 & 0.1184 & 0.4187 & 64.27 \\
\hline \multirow{6}{*}{3.50} & 100 & 0.9997 & 0.0000 & 0.3335 & 0.4998 & 0.0001 & 0.1666 & 0.4998 & 66.64 \\
\hline & 200 & 1.0000 & 0.0000 & 0.3344 & 0.4990 & 0.0010 & 0.1656 & 0.4979 & 66.53 \\
\hline & 300 & 1.0000 & 0.0000 & 0.3391 & 0.4943 & 0.0057 & 0.1609 & 0.4885 & 65.90 \\
\hline & 400 & 1.0000 & 0.0000 & 0.3502 & 0.4832 & 0.0168 & 0.1498 & 0.4663 & 64.42 \\
\hline & 500 & 1.0000 & 0.0000 & 0.3664 & 0.4669 & 0.0331 & 0.1336 & 0.4338 & 62.25 \\
\hline & 600 & 1.0000 & 0.0000 & 0.3840 & 0.4493 & 0.0507 & 0.1160 & 0.3987 & 59.91 \\
\hline \multirow{6}{*}{4.00} & 100 & 0.9999 & 0.0000 & 0.3847 & 0.4615 & 0.0000 & 0.1538 & 0.4614 & 61.53 \\
\hline & 200 & 1.0000 & 0.0000 & 0.3854 & 0.4608 & 0.0008 & 0.1531 & 0.4600 & 61.44 \\
\hline & 300 & 1.0000 & 0.0000 & 0.3889 & 0.4572 & 0.0043 & 0.1495 & 0.4529 & 60.97 \\
\hline & 400 & 1.0000 & 0.0000 & 0.3976 & 0.4486 & 0.0130 & 0.1409 & 0.4356 & 59.81 \\
\hline & 500 & 1.0000 & 0.0000 & 0.4109 & 0.4353 & 0.0263 & 0.1276 & 0.4090 & 58.03 \\
\hline & 600 & 1.0000 & 0.0000 & 0.4260 & 0.4201 & 0.0414 & 0.1124 & 0.3787 & 56.02 \\
\hline
\end{tabular}




\section{Appendix B}

\section{Compilation of Thermodynamic Data for DME-SR on a Dry Basis}

Thermodynamic Results for Dimethyl Ether Steam Reforming on a Dry Basis for S/C $=0.00-1.50$

\begin{tabular}{|c|c|c|c|c|c|c|c|}
\hline \multicolumn{2}{|c|}{ Operating Conditions } & \multirow[b]{2}{*}{$\begin{array}{l}\text { DME Fractional } \\
\text { Conversion }\end{array}$} & \multicolumn{4}{|c|}{ Effluent Mole Fractions } & \multirow{2}{*}{$\begin{array}{c}\text { Mole Fraction } \\
\text { Difference } \\
\left(\mathrm{y}_{\mathrm{H} 2}-\mathrm{y}_{\mathrm{CO}}\right)\end{array}$} \\
\hline $\mathrm{s} / \mathrm{C}$ & Temp $\left({ }^{\circ} \mathrm{C}\right)$ & & $\mathrm{CH}_{3} \mathrm{OCH}_{3}$ & $\mathrm{H}_{2}$ & $\mathrm{CO}$ & $\mathrm{CO}_{2}$ & \\
\hline \multirow{6}{*}{0.00} & 100 & 0.0000 & 1.0000 & 0.0000 & 0.0000 & 0.0000 & 0.0000 \\
\hline & 200 & 0.0000 & 1.0000 & 0.0000 & 0.0000 & 0.0000 & 0.0000 \\
\hline & 300 & 0.0000 & 1.0000 & 0.0000 & 0.0000 & 0.0000 & 0.0000 \\
\hline & 400 & 0.0000 & 1.0000 & 0.0000 & 0.0000 & 0.0000 & 0.0000 \\
\hline & 500 & 0.0000 & 1.0000 & 0.0000 & 0.0000 & 0.0000 & 0.0000 \\
\hline & 600 & 0.0000 & 0.9998 & 0.0001 & 0.0000 & 0.0000 & 0.0001 \\
\hline \multirow{6}{*}{0.25} & 100 & 0.1609 & 0.3954 & 0.4530 & 0.0018 & 0.1498 & 0.4512 \\
\hline & 200 & 0.3978 & 0.1949 & 0.5477 & 0.2248 & 0.0327 & 0.3229 \\
\hline & 300 & 0.5000 & 0.1429 & 0.5714 & 0.2857 & 0.0000 & 0.2857 \\
\hline & 400 & 0.5000 & 0.1429 & 0.5714 & 0.2857 & 0.0000 & 0.2857 \\
\hline & 500 & 0.5000 & 0.1429 & 0.5714 & 0.2857 & 0.0000 & 0.2857 \\
\hline & 600 & 0.5000 & 0.1429 & 0.5714 & 0.2857 & 0.0000 & 0.2857 \\
\hline \multirow{6}{*}{0.50} & 100 & 0.3097 & 0.2182 & 0.5860 & 0.0013 & 0.1945 & 0.5847 \\
\hline & 200 & 0.6272 & 0.0828 & 0.6387 & 0.1968 & 0.0817 & 0.4419 \\
\hline & 300 & 0.9961 & 0.0007 & 0.6664 & 0.3323 & 0.0006 & 0.3341 \\
\hline & 400 & 0.9999 & 0.0000 & 0.6667 & 0.3333 & 0.0000 & 0.3333 \\
\hline & 500 & 1.0000 & 0.0000 & 0.6667 & 0.3333 & 0.0000 & 0.3333 \\
\hline & 600 & 1.0000 & 0.0000 & 0.6667 & 0.3333 & 0.0000 & 0.3333 \\
\hline \multirow{6}{*}{0.75} & 100 & 0.4510 & 0.1322 & 0.6506 & 0.0010 & 0.2162 & 0.6495 \\
\hline & 200 & 0.7969 & 0.0358 & 0.6834 & 0.1591 & 0.1217 & 0.5242 \\
\hline & 300 & 1.0000 & 0.0000 & 0.6907 & 0.2371 & 0.0722 & 0.4536 \\
\hline & 400 & 1.0000 & 0.0000 & 0.6879 & 0.2484 & 0.0637 & 0.4395 \\
\hline & 500 & 1.0000 & 0.0000 & 0.6842 & 0.2634 & 0.0525 & 0.4208 \\
\hline & 600 & 1.0000 & 0.0000 & 0.6806 & 0.2777 & 0.0417 & 0.4029 \\
\hline \multirow{6}{*}{1.00} & 100 & 0.5850 & 0.0815 & 0.6886 & 0.0009 & 0.2290 & 0.6878 \\
\hline & 200 & 0.9179 & 0.0124 & 0.7114 & 0.1175 & 0.1588 & 0.5939 \\
\hline & 300 & 1.0000 & 0.0000 & 0.7102 & 0.1591 & 0.1307 & 0.5511 \\
\hline & 400 & 1.0000 & 0.0000 & 0.7042 & 0.1832 & 0.1126 & 0.5211 \\
\hline & 500 & 1.0000 & 0.0000 & 0.6974 & 0.2106 & 0.0921 & 0.4868 \\
\hline & 600 & 1.0000 & 0.0000 & 0.6912 & 0.2352 & 0.0736 & 0.4561 \\
\hline \multirow{6}{*}{1.25} & 100 & 0.7098 & 0.0487 & 0.7133 & 0.0007 & 0.2373 & 0.7126 \\
\hline & 200 & 0.9836 & 0.0022 & 0.7309 & 0.0699 & 0.1971 & 0.6610 \\
\hline & 300 & 1.0000 & 0.0000 & 0.7250 & 0.0998 & 0.1751 & 0.6252 \\
\hline & 400 & 1.0000 & 0.0000 & 0.7162 & 0.1351 & 0.1487 & 0.5811 \\
\hline & 500 & 1.0000 & 0.0000 & 0.7072 & 0.1710 & 0.1217 & 0.5362 \\
\hline & 600 & 1.0000 & 0.0000 & 0.6995 & 0.2022 & 0.0984 & 0.4973 \\
\hline \multirow{6}{*}{1.50} & 100 & 0.8212 & 0.0265 & 0.7300 & 0.0006 & 0.2429 & 0.7294 \\
\hline & 200 & 0.9992 & 0.0001 & 0.7432 & 0.0267 & 0.2299 & 0.7165 \\
\hline & 300 & 1.0000 & 0.0000 & 0.7349 & 0.0606 & 0.2046 & 0.6743 \\
\hline & 400 & 1.0000 & 0.0000 & 0.7247 & 0.1013 & 0.1740 & 0.6233 \\
\hline & 500 & 1.0000 & 0.0000 & 0.7147 & 0.1414 & 0.1440 & 0.5733 \\
\hline & 600 & 1.0000 & 0.0000 & 0.7059 & 0.1762 & 0.1178 & 0.5297 \\
\hline
\end{tabular}




\section{Appendix B (Continued)}

Thermodynamic Results for Dimethyl Ether Steam Reforming on a Dry Basis for S/C $=1.75-4.00$

\begin{tabular}{|c|c|c|c|c|c|c|c|}
\hline \multicolumn{2}{|c|}{ Operating Conditions } & \multirow{2}{*}{$\begin{array}{c}\text { DME Fractional } \\
\text { Conversion }\end{array}$} & \multicolumn{4}{|c|}{ Effluent Mole Fractions } & \multirow{2}{*}{$\begin{array}{c}\begin{array}{c}\text { Mole Fraction } \\
\text { Difference }\end{array} \\
\left(\mathrm{y}_{\mathrm{H} 2}-\mathrm{y}_{\mathrm{co}}\right)\end{array}$} \\
\hline $\mathrm{s} / \mathrm{C}$ & Temp $\left({ }^{\circ} \mathrm{C}\right)$ & & $\mathrm{CH}_{3} \mathrm{OCH}_{3}$ & $\mathrm{H}_{2}$ & $\mathrm{CO}$ & $\mathrm{CO}_{2}$ & \\
\hline \multirow{6}{*}{1.75} & 100 & 0.9104 & 0.0122 & 0.7408 & 0.0005 & 0.2466 & 0.7403 \\
\hline & 200 & 1.0000 & 0.0000 & 0.7474 & 0.0104 & 0.2422 & 0.7370 \\
\hline & 300 & 1.0000 & 0.0000 & 0.7403 & 0.0386 & 0.2210 & 0.7017 \\
\hline & 400 & 1.0000 & 0.0000 & 0.7305 & 0.0782 & 0.1914 & 0.6523 \\
\hline & 500 & 1.0000 & 0.0000 & 0.7202 & 0.1190 & 0.1607 & 0.6012 \\
\hline & 600 & 1.0000 & 0.0000 & 0.7111 & 0.1555 & 0.1334 & 0.5556 \\
\hline \multirow{6}{*}{2.00} & 100 & 0.9652 & 0.0045 & 0.7465 & 0.0003 & 0.2486 & 0.7462 \\
\hline & 200 & 1.0000 & 0.0000 & 0.7485 & 0.0059 & 0.2456 & 0.7426 \\
\hline & 300 & 1.0000 & 0.0000 & 0.7433 & 0.0269 & 0.2298 & 0.7164 \\
\hline & 400 & 1.0000 & 0.0000 & 0.7344 & 0.0623 & 0.2033 & 0.6721 \\
\hline & 500 & 1.0000 & 0.0000 & 0.7245 & 0.1020 & 0.1735 & 0.6226 \\
\hline & 600 & 1.0000 & 0.0000 & 0.7153 & 0.1387 & 0.1460 & 0.5766 \\
\hline \multirow{6}{*}{2.50} & 100 & 0.9954 & 0.0006 & 0.7495 & 0.0002 & 0.2497 & 0.7493 \\
\hline & 200 & 1.0000 & 0.0000 & 0.7492 & 0.0031 & 0.2477 & 0.7461 \\
\hline & 300 & 1.0000 & 0.0000 & 0.7460 & 0.0161 & 0.2380 & 0.7299 \\
\hline & 400 & 1.0000 & 0.0000 & 0.7392 & 0.0431 & 0.2177 & 0.6961 \\
\hline & 500 & 1.0000 & 0.0000 & 0.7305 & 0.0782 & 0.1914 & 0.6523 \\
\hline & 600 & 1.0000 & 0.0000 & 0.7216 & 0.1134 & 0.1649 & 0.6082 \\
\hline \multirow{6}{*}{3.00} & 100 & 0.9990 & 0.0001 & 0.7499 & 0.0001 & 0.2499 & 0.7497 \\
\hline & 200 & 1.0000 & 0.0000 & 0.7495 & 0.0021 & 0.2484 & 0.7474 \\
\hline & 300 & 1.0000 & 0.0000 & 0.7472 & 0.0113 & 0.2415 & 0.7359 \\
\hline & 400 & 1.0000 & 0.0000 & 0.7419 & 0.0325 & 0.2256 & 0.7094 \\
\hline & 500 & 1.0000 & 0.0000 & 0.7343 & 0.0628 & 0.2029 & 0.6715 \\
\hline & 600 & 1.0000 & 0.0000 & 0.7261 & 0.0955 & 0.1784 & 0.6306 \\
\hline \multirow{6}{*}{3.50} & 100 & 0.9997 & 0.0000 & 0.7499 & 0.0001 & 0.2499 & 0.7498 \\
\hline & 200 & 1.0000 & 0.0000 & 0.7496 & 0.0016 & 0.2488 & 0.7480 \\
\hline & 300 & 1.0000 & 0.0000 & 0.7478 & 0.0087 & 0.2435 & 0.7392 \\
\hline & 400 & 1.0000 & 0.0000 & 0.7435 & 0.0259 & 0.2306 & 0.7176 \\
\hline & 500 & 1.0000 & 0.0000 & 0.7369 & 0.0522 & 0.2108 & 0.6847 \\
\hline & 600 & 1.0000 & 0.0000 & 0.7294 & 0.0823 & 0.1883 & 0.6472 \\
\hline \multirow{6}{*}{4.00} & 100 & 0.9999 & 0.0000 & 0.7500 & 0.0001 & 0.2499 & 0.7499 \\
\hline & 200 & 1.0000 & 0.0000 & 0.7497 & 0.0013 & 0.2491 & 0.7484 \\
\hline & 300 & 1.0000 & 0.0000 & 0.7482 & 0.0070 & 0.2447 & 0.7412 \\
\hline & 400 & 1.0000 & 0.0000 & 0.7446 & 0.0215 & 0.2339 & 0.7231 \\
\hline & 500 & 1.0000 & 0.0000 & 0.7388 & 0.0446 & 0.2165 & 0.6942 \\
\hline & 600 & 1.0000 & 0.0000 & 0.7320 & 0.0721 & 0.1959 & 0.6598 \\
\hline
\end{tabular}




\section{Appendix C}

Enlarged Plots of the Thermodynamic Results Contained in the Text

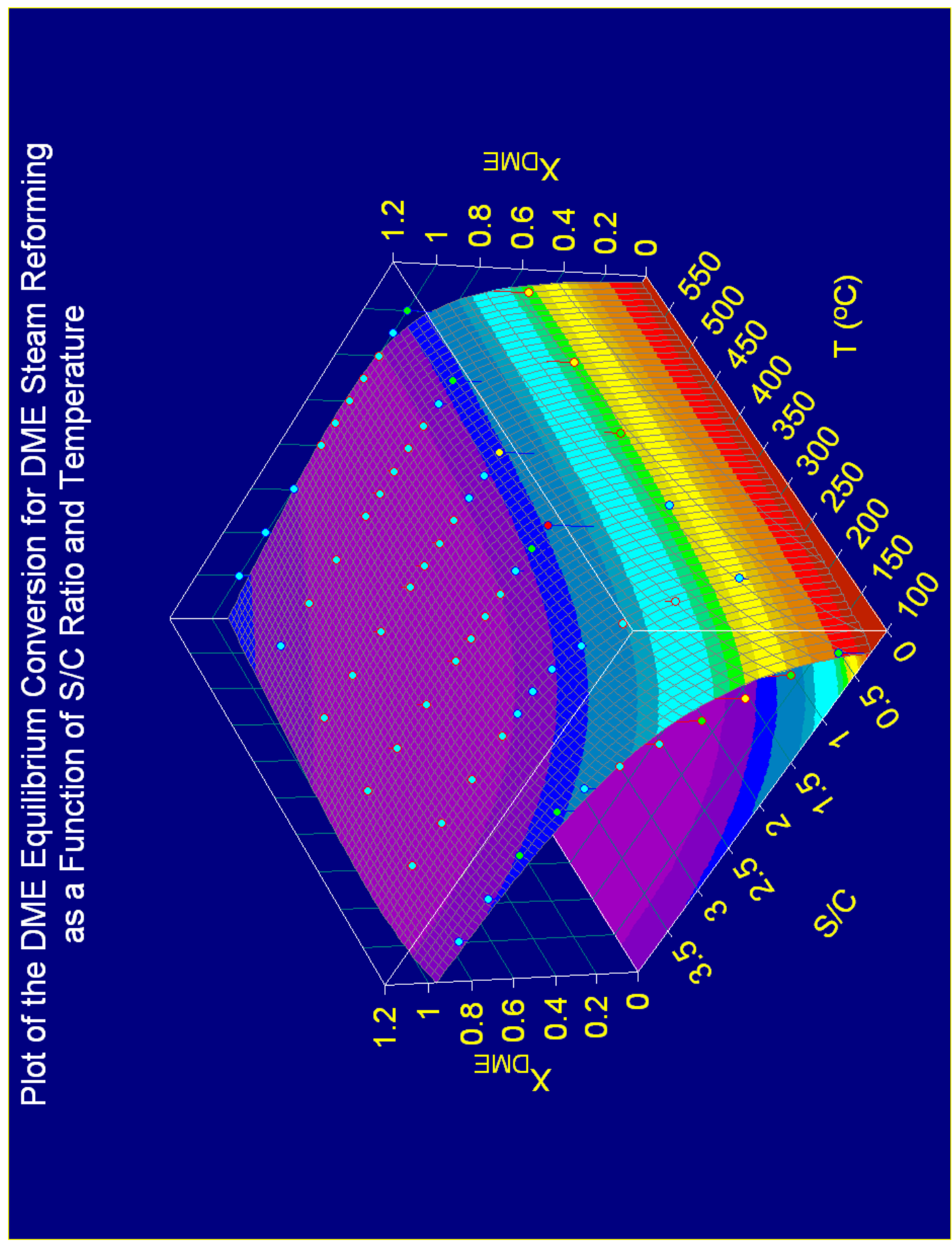




\section{Appendix C (Continued)}

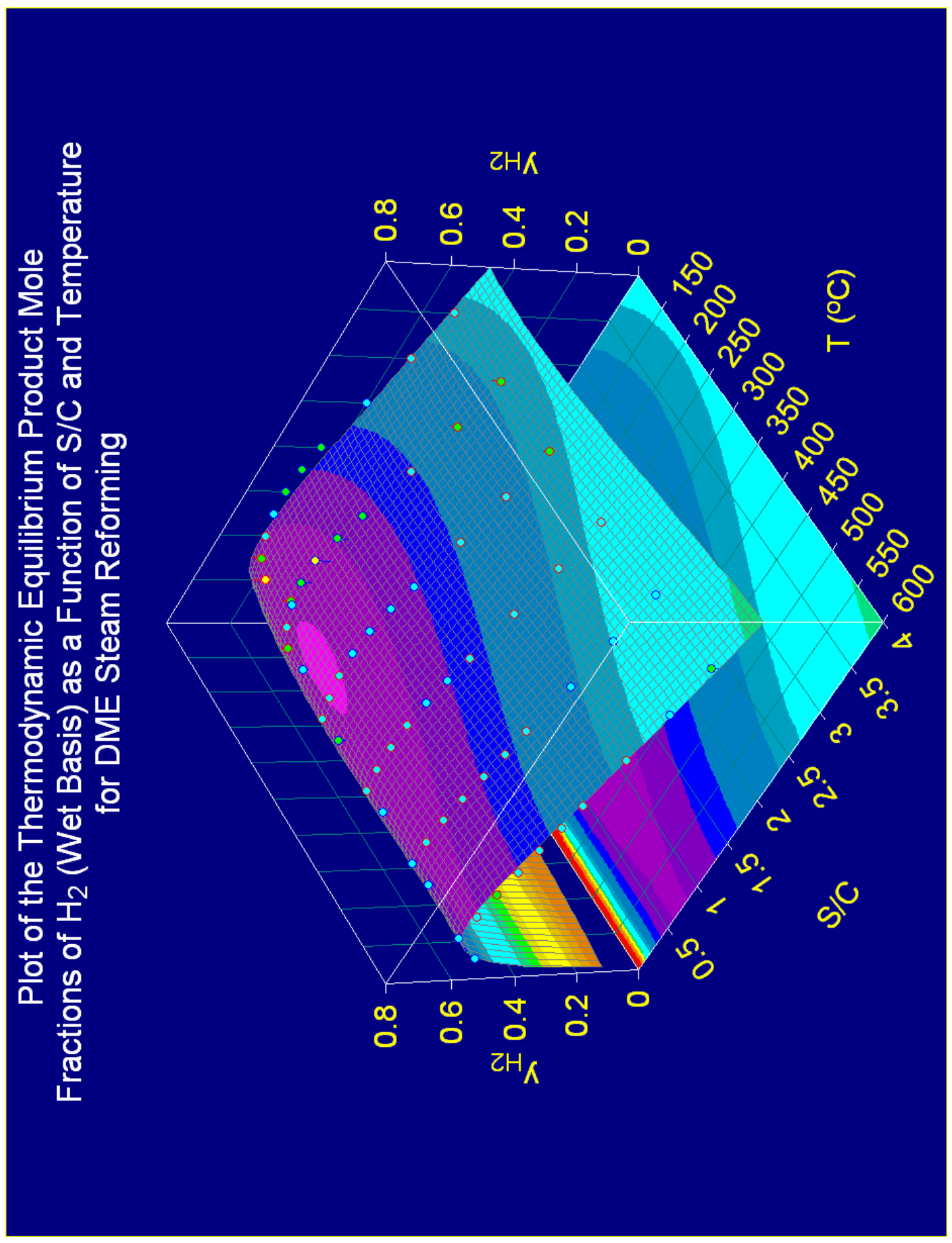




\section{Appendix C (Continued)}

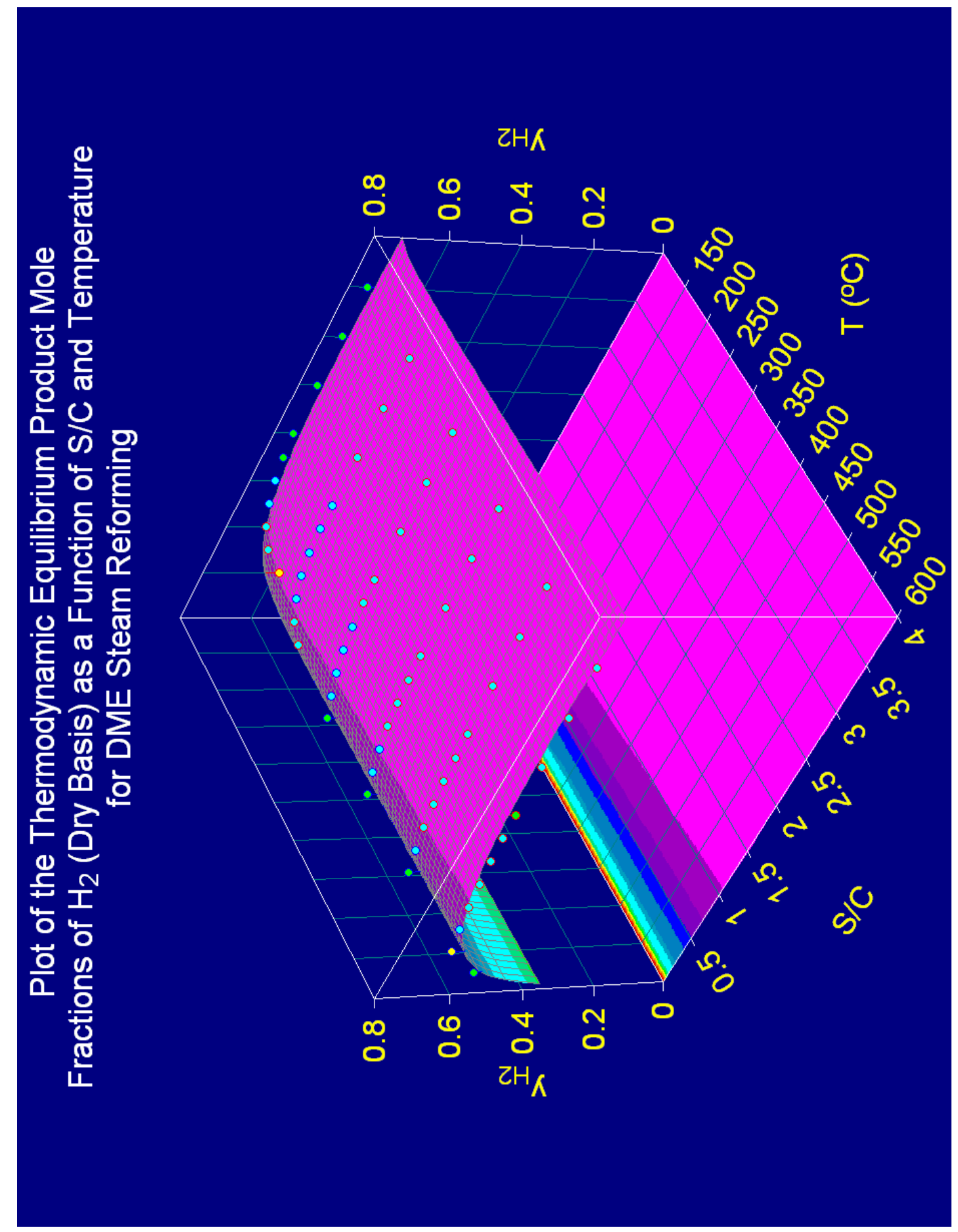




\section{Appendix C (Continued)}

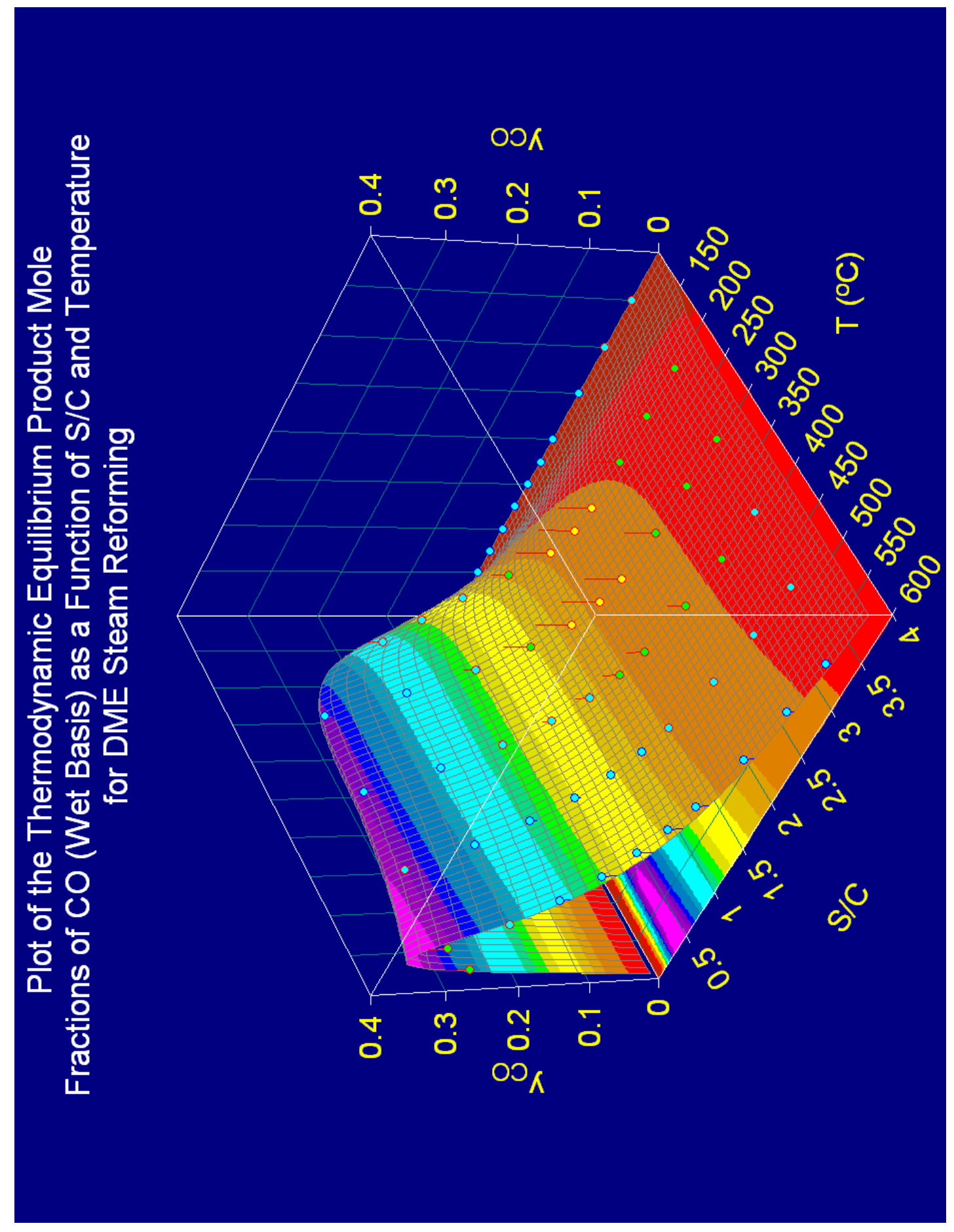




\section{Appendix C (Continued)}

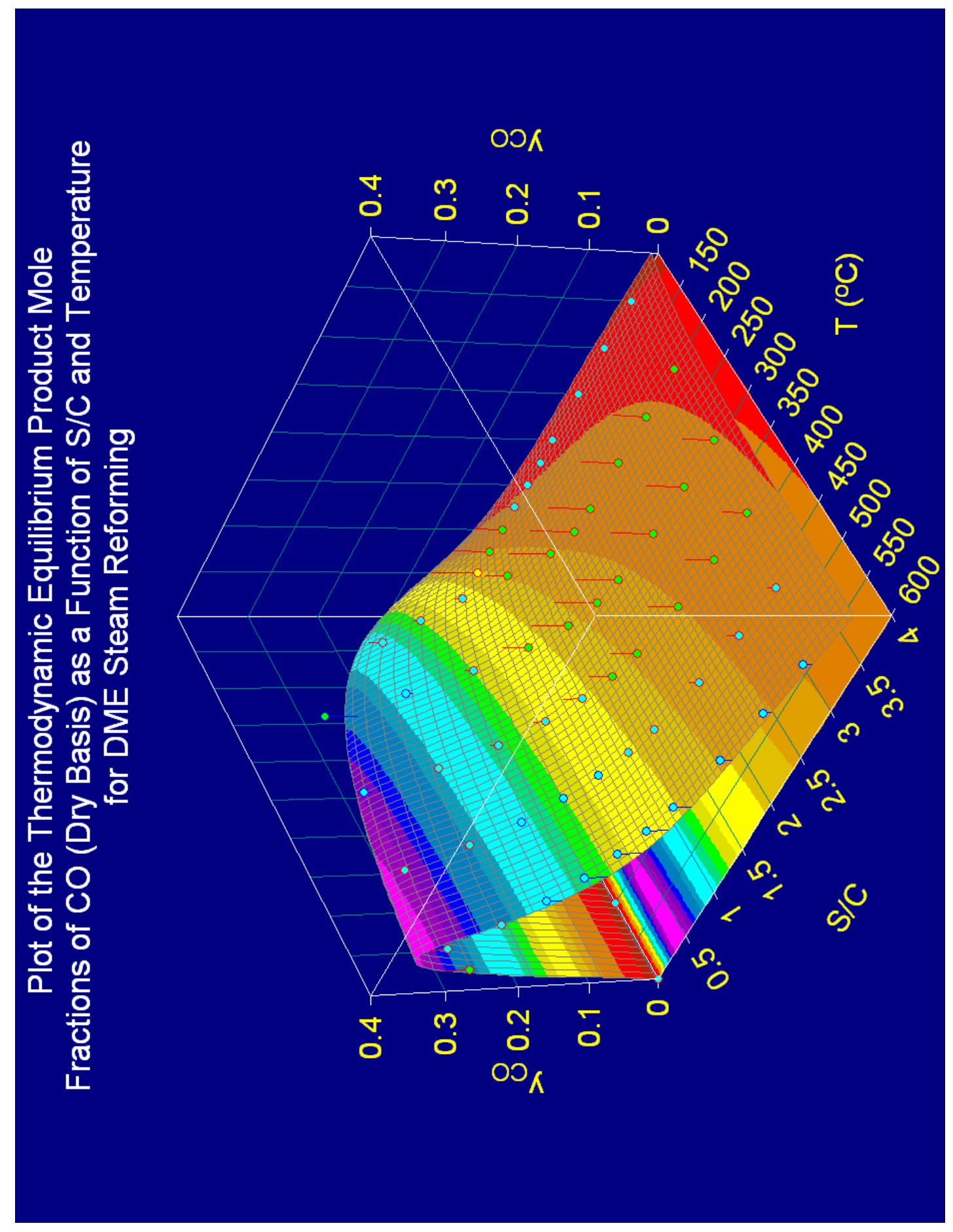




\section{Appendix C (Continued)}

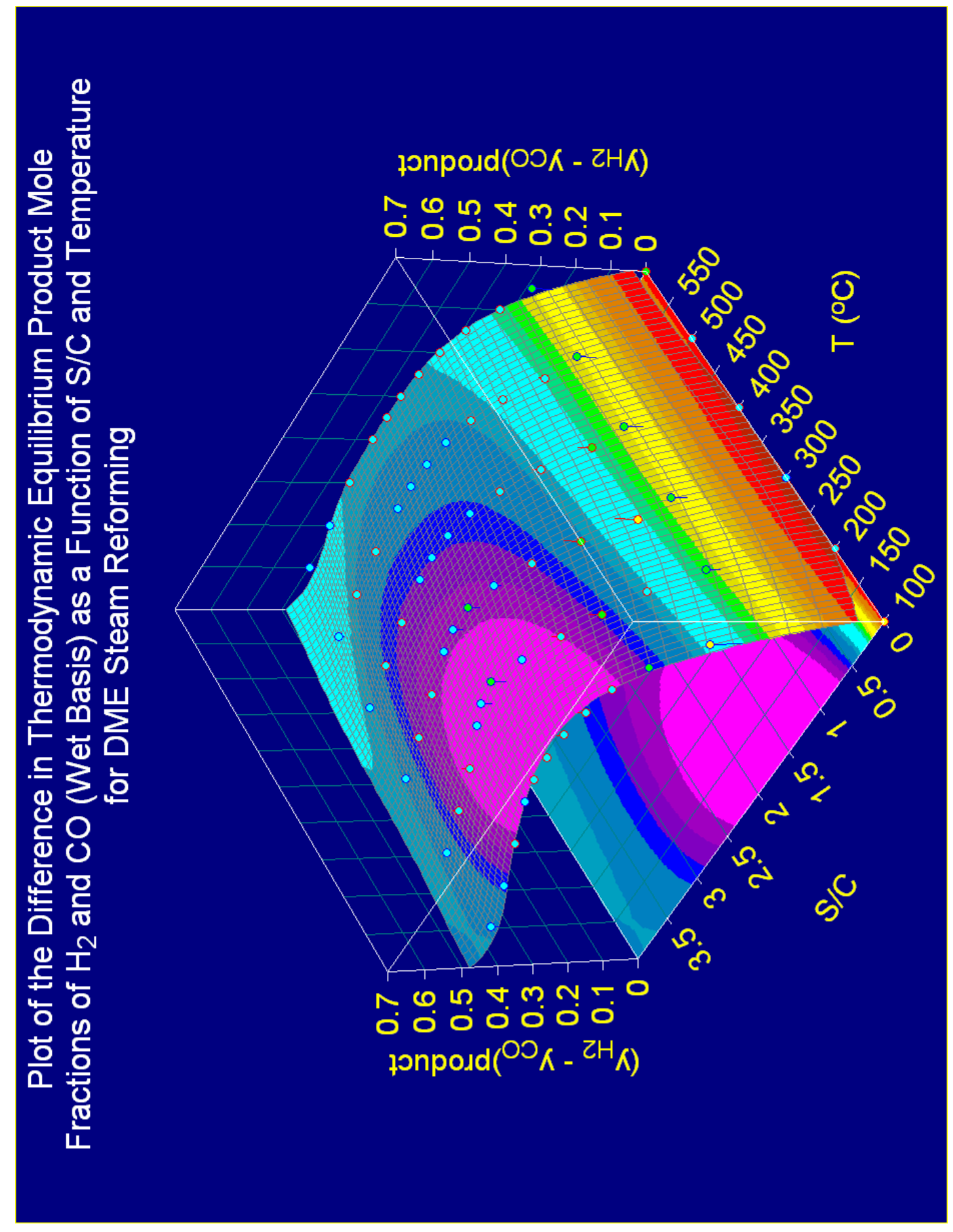




\section{Appendix C (Continued)}

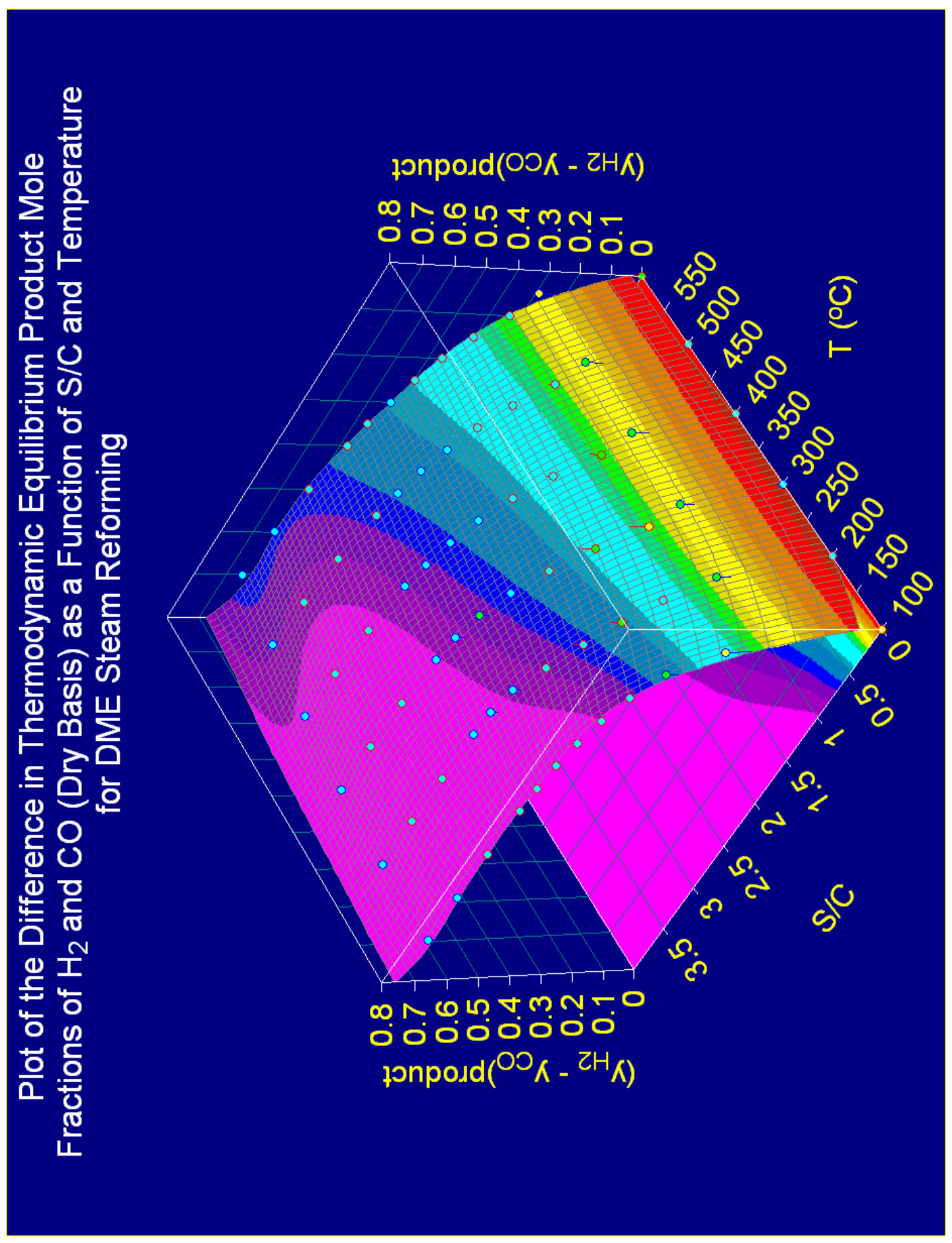




\section{Appendix D}

Plot of the DME-SR Hydrogen Production Efficiency on a Wet Basis

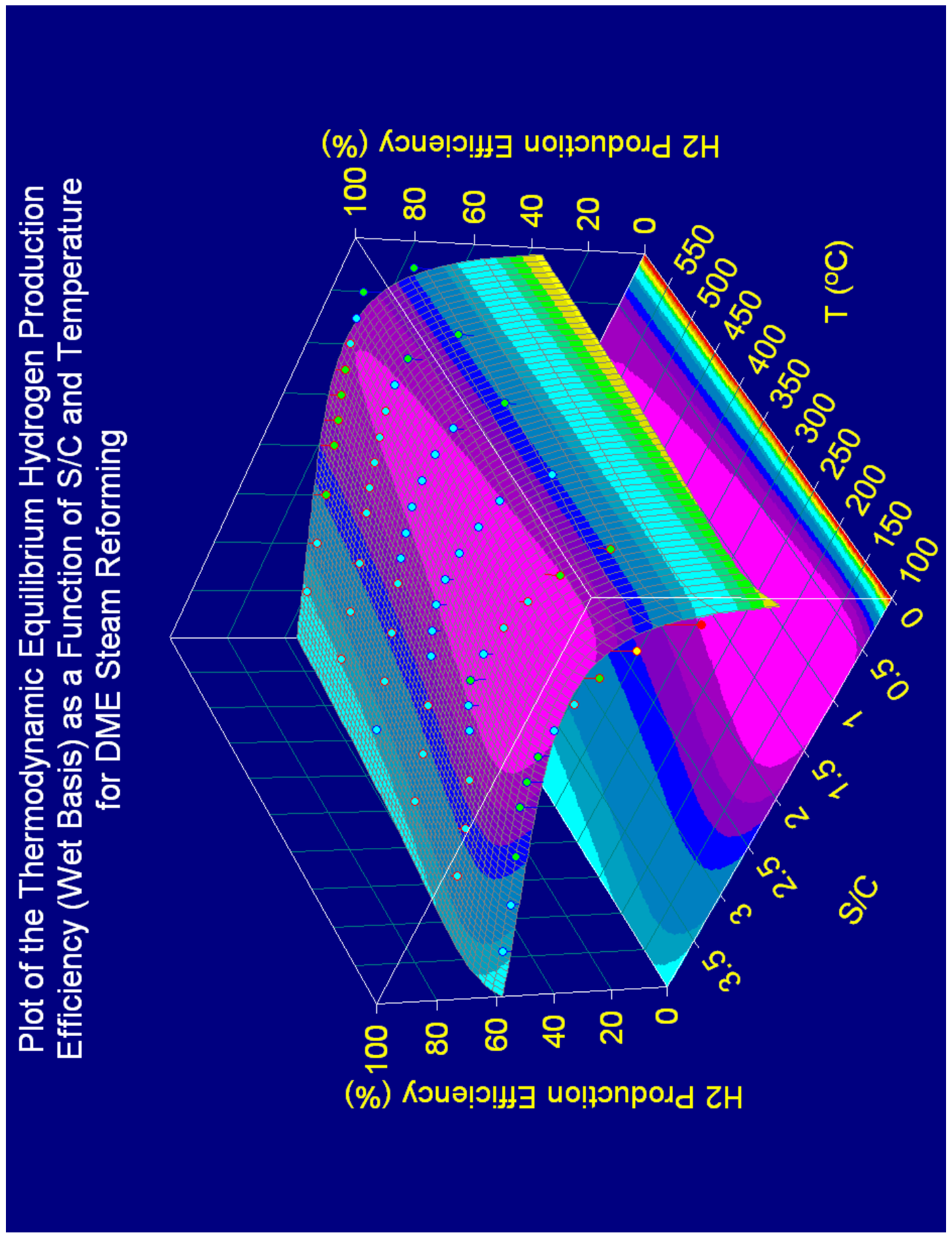




\section{Appendix E}

\section{DME-SR Carbon Monoxide Plots}
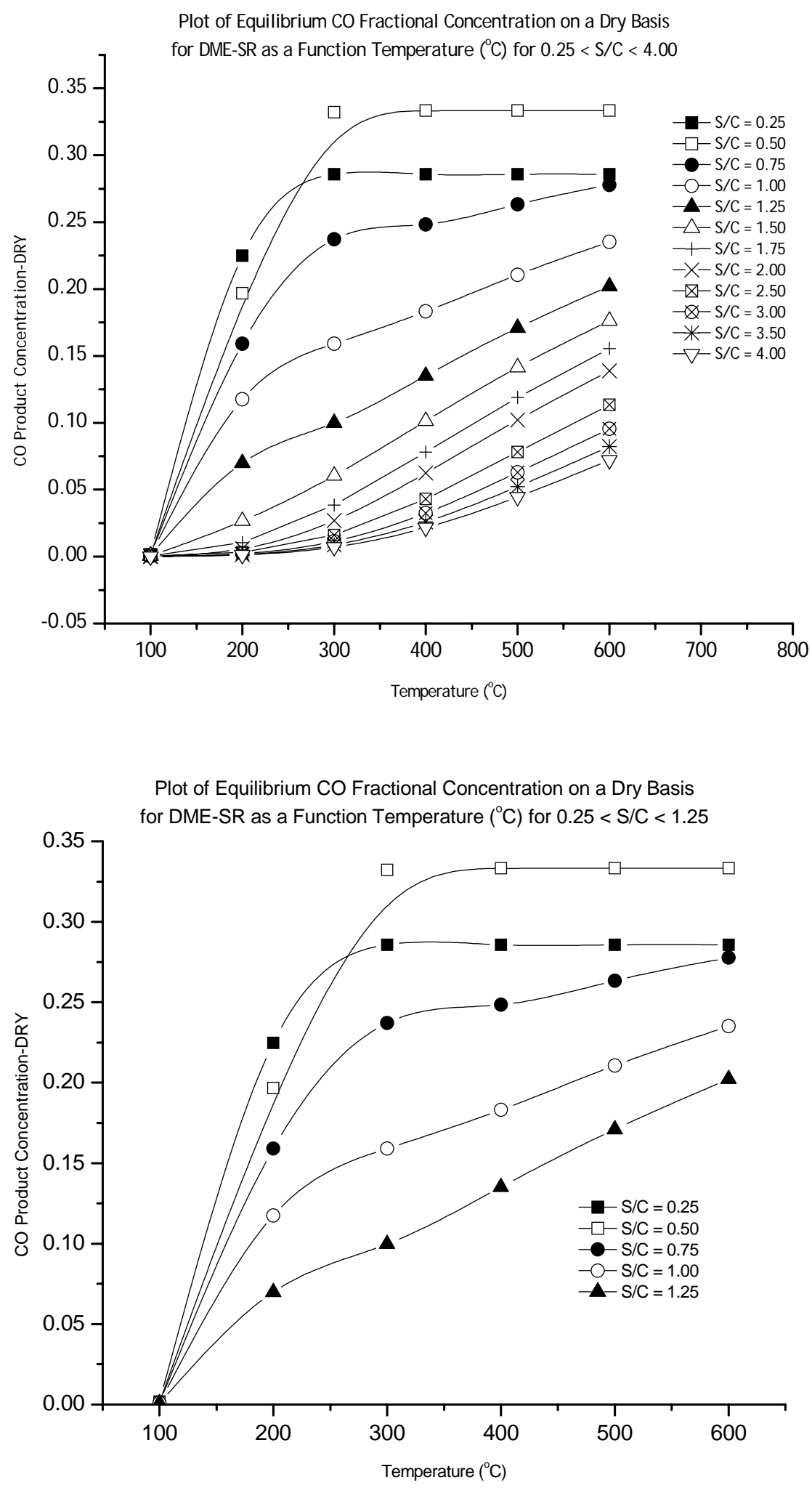


\section{Appendix E (Continued)}
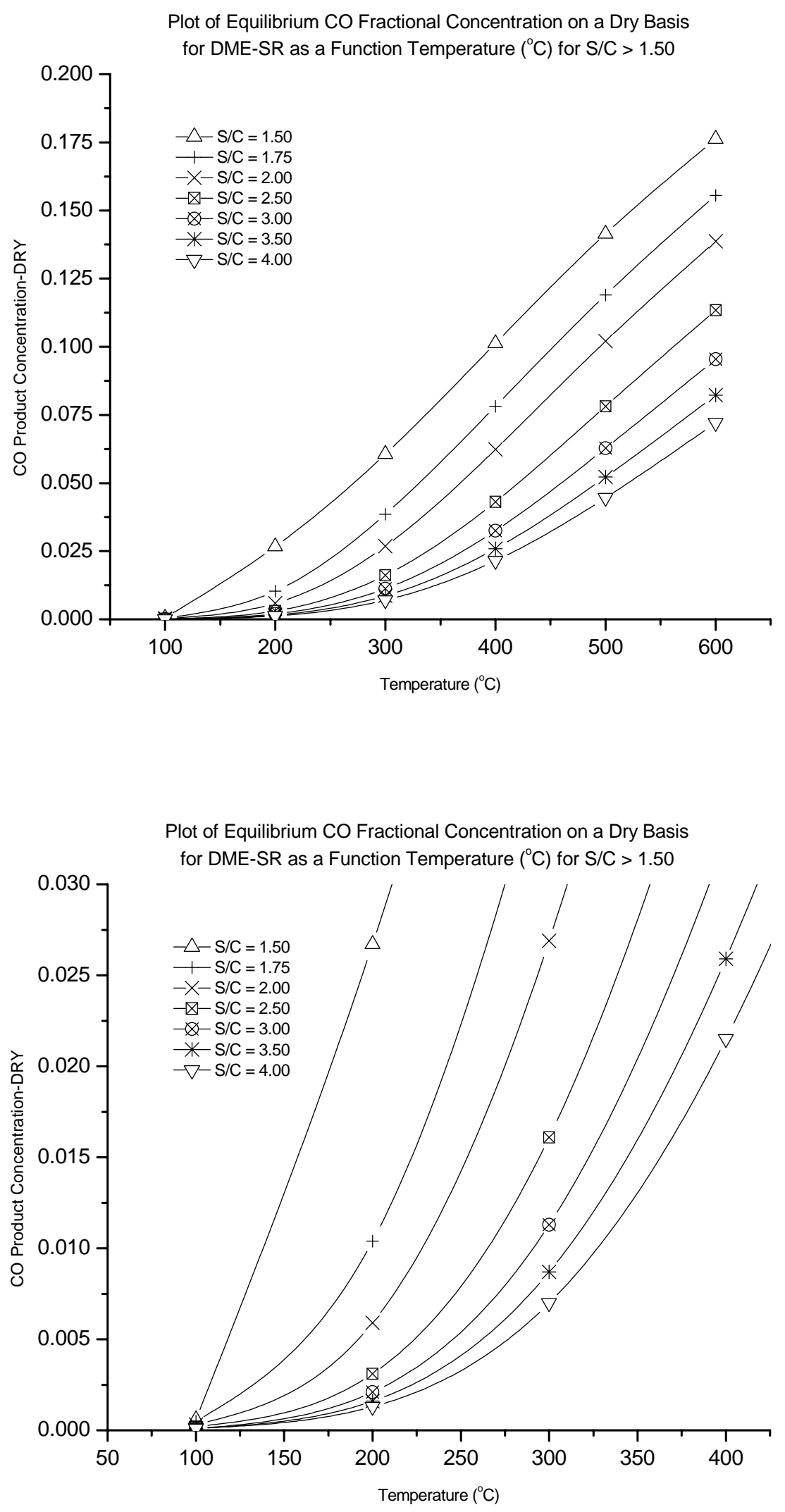


\section{Appendix F}

\section{Compilation of DME-SR Results on a Wet Basis for Thermodynamically Viable Products Processed at a $\mathrm{S} / \mathrm{C}=\mathbf{2 . 5}$ and $\mathrm{P}=1 \mathrm{~atm}$}

For all thermodynamic cases the conversion of DME was 1.00: for clarity all products with fractional concentrations of 0.0000 were not displayed and species in bold are the dominant species for that thermodynamic case

$$
\text { है․․ }
$$

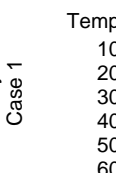

Water

Water
0.7135
0.7084
0.6780
0.5920
0.4563
0.3362

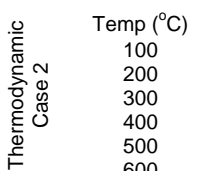

Water

0.8216

0.7714
0.5971

0.3533

0.2585

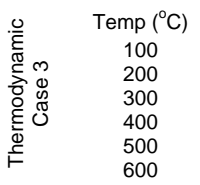

Water

0.7903

0.4794
0.2549

0.2328

0.2328
0.2573

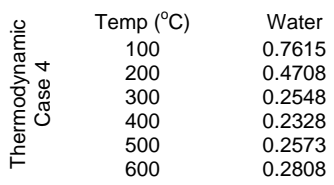

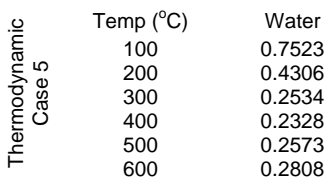

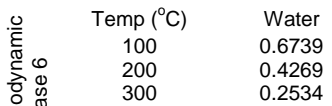

0.2534

0.2328
0.2573

$\begin{array}{ccc} & \text { Temp }\left({ }^{\circ} \mathrm{C}\right) & \text { Water } \\ & 100 & 0.6331 \\ & 200 & 0.2739\end{array}$

\begin{tabular}{lll} 
& & \\
$\sum_{0} \Uparrow$ & 200 & 0.2739 \\
\hdashline & 300 & 0.2118
\end{tabular}

0.2118
0.2323
0.2573

0.2573
0.2808

$\mathrm{H} 2$

0.0003

0.0064

0.0418

0.1425
0.3032

0.4508

$\mathrm{H} 2$

0.0040
0.0522

0.0522
0.2191

0.2191

0.5413
0.5190

$\mathrm{H} 2$

0.0885
0.3592

0.3592

0.5492

0.5670

0.5425
0.5190

$\mathrm{H} 2$
0.1284

0.1284

0.3679

0.5493

0.5670
0.5425

0.5425
0.5190

$\mathrm{H} 2$

0.1176

0.3901

0.5502
0.5670

0.5670
0.5425

0.5190

$\mathrm{H} 2$

0.1633

0.3925

0.5502
0.5670

0.5670
0.5425

0.5190

$\mathrm{H} 2$

0.1895

0.5297
0.5879

0.5879
0.5675

0.5425

0.5190

CO

0.0000

0.0000

0.0001

0.0020

0.0160

0.0604

CO
0.0000
0.0000
0.0009
0.0156
0.0578
0.0817

0.081

CO
0.0000

0.0004

0.0093

0.0331

0.0582
0.0817

Product Fractional Concentrations- Wet Basis

CO
0.0000
0.0004
0.0093
0.0331
0.0582
0.0817

co

0.0000
0.0005

0.0005
0.0094

0.0094
0.0331

0.0582

0.0817

$\mathrm{CO}$

0.0000

0.0000
0.0005

0.0094

0.0331

0.0582
0.0817

$\mathrm{CO}$

0.0000

0.0014
0.0127

0.0127
0.0332

0.0332
0.0582

0.0817

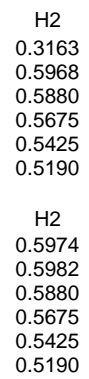

CO
0.0000
0.0024
0.0127
0.0332
0.0582
0.0817

CO
0.0002
0.0025
0.0127
0.0332
0.0582
0.0817
$\mathrm{CO} 2$

0.0716

0.0729

0.0804

0.1005

0.1239
0.1207

$\mathrm{CO} 2$

$\mathrm{CO} 2$
0.0446
0.0571

0.1000

0.1499

0.1420

$\mathrm{CO} 2$

0.0253

0.1116

0.1767

0.1669
0.1420

0.1185

CO2

0.0163

0.1119

0.1767

0.1669

0.1420
0.1185

$\mathrm{CO} 2$

0.0392

0.1297

0.1771
0.1669

0.1420

0.1185

$\mathrm{CO} 2$

0.0544

0.1305

0.1771
0.1669

0.1420
0.1185

$\mathrm{CO} 2$

0.0631

0.0631
0.1756

0.1875

0.1670

0.1420

0.1185

$\mathrm{CO} 2$

0.1054
0.1973

0.1973
0.1875

0.1875

0.1420

0.1185

$\mathrm{CO} 2$

0.1990

0.1977

0.1875

0.1420
0.1185
Methane

0.2145

0.2124

0.1630

0.1006

0.0320

Ethane

0.1298

0.1193

0.0828

0.0003

0.0000

Ethylene

0.0002

0.0133

0.0094

0.0001

0.0000
0.0000

Ethylene

0.0010

0.0166

0.0094

0.0001

0.0000
0.0000

Ethylene

0.0037

0.0451

0.0098

0.0001

0.0000
0.0000

Ethanol

0.0288

0.0005
0.0000

0.0000

0.0000
0.0000

Ethanol

0.1143

0.0193

0.0000

0.0000

0.0000
0.0000

Methyl

ethyl ether

0.0527

0.0003

0.0000

0.0000

0.0000

Methanol

0.0009

0.0000

0.0000

0.0000

0.0000
0.0000

$\begin{array}{cccc}\text { Ethanol } & \text { Acetone } & \text { n-propanol } & \text { Isopropanol } \\ 0.0001 & 0.0126 & 0.0014 & \mathbf{0 . 0 8 1 7} \\ 0.0001 & 0.0236 & 0.0006 & \mathbf{0 . 0 1 1 7} \\ 0.0000 & 0.0005 & 0.0000 & \mathbf{0 . 0 0 0 0} \\ 0.0000 & 0.0000 & 0.0000 & \mathbf{0 . 0 0 0 0} \\ 0.0000 & 0.0000 & 0.0000 & \mathbf{0 . 0 0 0 0} \\ 0.0000 & 0.0000 & 0.0000 & \mathbf{0 . 0 0 0 0}\end{array}$

Ethanol n-propanol Acetone

$\begin{array}{lll}0.0004 & 0.0128 & \mathbf{0 . 0 7 9 5}\end{array}$

$\begin{array}{lll}0.0002 & 0.0009 & \mathbf{0 . 0 3 1 5}\end{array}$

$\begin{array}{lll}0.0000 & 0.0000 & \mathbf{0 . 0 0 0 5}\end{array}$

$\begin{array}{lll}0.0000 & 0.0000 & \mathbf{0 . 0 0 0 0}\end{array}$

$\begin{array}{lll}0.0000 & 0.0000 & \mathbf{0 . 0 0 0 0}\end{array}$

$\begin{array}{lll}0.0000 & 0.0000 & \mathbf{0 . 0 0 0 0}\end{array}$

Ethanol n-propanol

$0.0015 \quad 0.0856$

$0.0004 \quad \mathbf{0 . 0 0 3 6}$

$\begin{array}{ll}0.0000 & \mathbf{0 . 0 0 0 0}\end{array}$

$\begin{array}{ll}0.0000 & \mathbf{0 . 0 0 0 0}\end{array}$

$0.0000 \quad \mathbf{0 . 0 0 0 0}$

$0.0000 \quad \mathbf{0 . 0 0 0 0}$

Ethylene

0.0795

0.0491

0.0098

0.0001

0.0000
0.0000 


\section{Appendix G}

\section{Compilation of DME-SR Results on a Dry Basis for Thermodynamically Viable Products Processed at a $\mathrm{S} / \mathrm{C}=2.5$ and $\mathrm{P}=1 \mathrm{~atm}$}

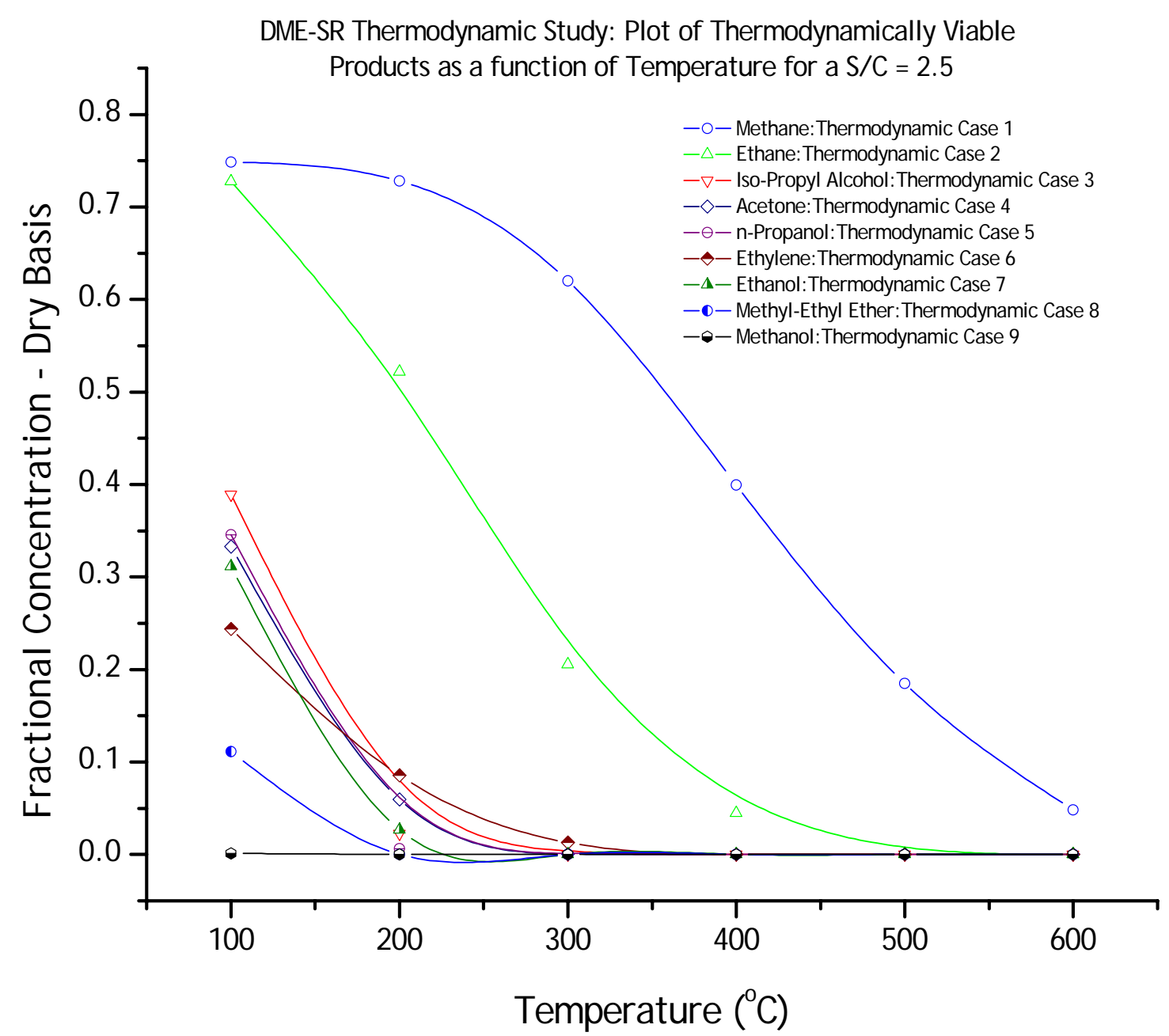




\section{Appendix H \\ Compilation of Thermodynamic Data for DME Hydrolysis}

\begin{tabular}{|c|c|c|c|c|c|}
\hline \multirow{2}{*}{$\begin{array}{l}\text { Thern } \\
\text { S/C } \\
\end{array}$} & \multirow{2}{*}{$\begin{array}{c}\text { namic Results } \\
\text { Temperature } \\
\left({ }^{\circ} \mathrm{C}\right) \\
\end{array}$} & \multirow{2}{*}{$\begin{array}{l}\text { Dimethyl Et } \\
\text { DME } \\
\text { Conversion } \\
\end{array}$} & \multicolumn{3}{|c|}{$\begin{array}{c}\text { ydrolysis on a Wet Basis for } \mathbf{S} / \mathrm{C}=\mathbf{0 . 0 0 0}-\mathbf{0 . 1} \\
\text { Fractional Concentration: Wet Basis }\end{array}$} \\
\hline & & & $\mathrm{CH}_{3} \mathrm{OCH}_{3}$ & $\mathrm{H}_{2} \mathrm{O}$ & $\mathrm{CH}_{3} \mathrm{OH}$ \\
\hline \multirow{6}{*}{\begin{tabular}{l}
8 \\
$\varnothing$ \\
\hdashline
\end{tabular}} & 100 & 0.0000 & 1.0000 & 0.0000 & 0.0000 \\
\hline & 200 & 0.0000 & 1.0000 & 0.0000 & 0.0000 \\
\hline & 300 & 0.0000 & 1.0000 & 0.0000 & 0.0000 \\
\hline & 400 & 0.0000 & 1.0000 & 0.0000 & 0.0000 \\
\hline & 500 & 0.0000 & 1.0000 & 0.0000 & 0.0000 \\
\hline & 600 & 0.0000 & 1.0000 & 0.0000 & 0.0000 \\
\hline \multirow{6}{*}{$\begin{array}{l}8 \\
\text { ڤn } \\
0 \\
0\end{array}$} & 100 & 0.0131 & 0.8972 & 0.0790 & 0.0238 \\
\hline & 200 & 0.0259 & 0.8856 & 0.0674 & 0.0471 \\
\hline & 300 & 0.0380 & 0.8745 & 0.0563 & 0.0691 \\
\hline & 400 & 0.0480 & 0.8655 & 0.0473 & 0.0872 \\
\hline & 500 & 0.0557 & 0.8585 & 0.0403 & 0.1013 \\
\hline & 600 & 0.0616 & 0.8531 & 0.0349 & 0.1120 \\
\hline \multirow{6}{*}{$\begin{array}{l}\circ \\
\text { Lొ } \\
\stackrel{0}{0} \\
0\end{array}$} & 100 & 0.0138 & 0.8876 & 0.0876 & 0.0249 \\
\hline & 200 & 0.0275 & 0.8753 & 0.0753 & 0.0495 \\
\hline & 300 & 0.0405 & 0.8635 & 0.0635 & 0.0729 \\
\hline & 400 & 0.0513 & 0.8538 & 0.0538 & 0.0924 \\
\hline & 500 & 0.0598 & 0.8462 & 0.0462 & 0.1076 \\
\hline & 600 & 0.0663 & 0.8403 & 0.0403 & 0.1194 \\
\hline \multirow{6}{*}{$\begin{array}{l}\stackrel{L}{0} \\
\stackrel{0}{0} \\
\ddot{0}\end{array}$} & 100 & 0.0147 & 0.8758 & 0.0980 & 0.0262 \\
\hline & 200 & 0.0294 & 0.8628 & 0.0850 & 0.0522 \\
\hline & 300 & 0.0435 & 0.8502 & 0.0725 & 0.0773 \\
\hline & 400 & 0.0553 & 0.8397 & 0.0620 & 0.0983 \\
\hline & 500 & 0.0647 & 0.8314 & 0.0536 & 0.1150 \\
\hline & 600 & 0.0720 & 0.8249 & 0.0471 & 0.1280 \\
\hline \multirow{6}{*}{ 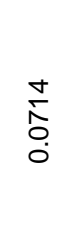 } & 100 & 0.0158 & 0.8612 & 0.1112 & 0.0276 \\
\hline & 200 & 0.0316 & 0.8473 & 0.0973 & 0.0553 \\
\hline & 300 & 0.0470 & 0.8338 & 0.0838 & 0.0823 \\
\hline & 400 & 0.0601 & 0.8224 & 0.0724 & 0.1052 \\
\hline & 500 & 0.0706 & 0.8133 & 0.0633 & 0.1235 \\
\hline & 600 & 0.0788 & 0.8060 & 0.0560 & 0.1379 \\
\hline \multirow{6}{*}{$\begin{array}{l}\mathscr{M}_{\infty} \\
\infty_{0} \\
0\end{array}$} & 100 & 0.0171 & 0.8425 & 0.1282 & 0.0293 \\
\hline & 200 & 0.0344 & 0.8276 & 0.1133 & 0.0590 \\
\hline & 300 & 0.0515 & 0.8130 & 0.0987 & 0.0882 \\
\hline & 400 & 0.0661 & 0.8005 & 0.0862 & 0.1132 \\
\hline & 500 & 0.0779 & 0.7904 & 0.0761 & 0.1335 \\
\hline & 600 & 0.0873 & 0.7823 & 0.0680 & 0.1497 \\
\hline \multirow{6}{*}{$\begin{array}{l}8 \\
0 \\
-1 \\
0\end{array}$} & 100 & 0.0188 & 0.8176 & 0.1510 & 0.0314 \\
\hline & 200 & 0.0380 & 0.8016 & 0.1350 & 0.0634 \\
\hline & 300 & 0.0571 & 0.7857 & 0.1190 & 0.0952 \\
\hline & 400 & 0.0737 & 0.7719 & 0.1052 & 0.1229 \\
\hline & 500 & 0.0873 & 0.7606 & 0.0939 & 0.1455 \\
\hline & 600 & 0.0983 & 0.7514 & 0.0848 & 0.1638 \\
\hline
\end{tabular}




\section{Appendix H (Continued) Compilation of Thermodynamic Data for DME Hydrolysis}

\begin{tabular}{|c|c|c|c|c|c|}
\hline \multirow{2}{*}{$\mathrm{S} / \mathrm{C}$} & \multirow{2}{*}{$\begin{array}{c}\text { Temperature } \\
\left({ }^{\circ} \mathrm{C}\right) \\
\end{array}$} & \multirow{2}{*}{$\begin{array}{c}\text { DME } \\
\text { Conversion } \\
\end{array}$} & \multicolumn{3}{|c|}{ Fractional Concentration: Wet Basis } \\
\hline & & & $\mathrm{CH}_{3} \mathrm{OCH}_{3}$ & $\mathrm{H}_{2} \mathrm{O}$ & $\mathrm{CH}_{3} \mathrm{OH}$ \\
\hline \multirow{6}{*}{\begin{tabular}{l}
-1 \\
\multirow{-}{7}{} \\
0 \\
0
\end{tabular}} & 100 & 0.0199 & 0.8019 & 0.1655 & 0.0325 \\
\hline & 200 & 0.0403 & 0.7852 & 0.1489 & 0.0659 \\
\hline & 300 & 0.0607 & 0.7686 & 0.1322 & 0.0993 \\
\hline & 400 & 0.0784 & 0.7540 & 0.1176 & 0.1284 \\
\hline & 500 & 0.0931 & 0.7420 & 0.1056 & 0.1524 \\
\hline & 600 & 0.1051 & 0.7322 & 0.0959 & 0.1719 \\
\hline \multirow{6}{*}{ 号 } & 100 & 0.0211 & 0.7831 & 0.1831 & 0.0338 \\
\hline & 200 & 0.0429 & 0.7657 & 0.1657 & 0.0686 \\
\hline & 300 & 0.0648 & 0.7482 & 0.1482 & 0.1037 \\
\hline & 400 & 0.0840 & 0.7328 & 0.1328 & 0.1344 \\
\hline & 500 & 0.1000 & 0.7200 & 0.1200 & 0.1600 \\
\hline & 600 & 0.1131 & 0.7095 & 0.1095 & 0.1809 \\
\hline \multirow{6}{*}{ 尽 } & 100 & 0.0226 & 0.7602 & 0.2046 & 0.0352 \\
\hline & 200 & 0.0461 & 0.7419 & 0.1864 & 0.0717 \\
\hline & 300 & 0.0698 & 0.7235 & 0.1679 & 0.1085 \\
\hline & 400 & 0.0907 & 0.7072 & 0.1516 & 0.1412 \\
\hline & 500 & 0.1083 & 0.6936 & 0.1380 & 0.1685 \\
\hline & 600 & 0.1227 & 0.6823 & 0.1268 & 0.1909 \\
\hline \multirow{6}{*}{ 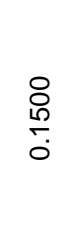 } & 100 & 0.0232 & 0.7514 & 0.2129 & 0.0357 \\
\hline & 200 & 0.0473 & 0.7329 & 0.1944 & 0.0728 \\
\hline & 300 & 0.0717 & 0.7141 & 0.1756 & 0.1103 \\
\hline & 400 & 0.0933 & 0.6975 & 0.1590 & 0.1435 \\
\hline & 500 & 0.1114 & 0.6835 & 0.1450 & 0.1714 \\
\hline & 600 & 0.1264 & 0.6720 & 0.1336 & 0.1944 \\
\hline \multirow{6}{*}{$\begin{array}{l}\text { î } \\
\stackrel{1}{1} \\
0\end{array}$} & 100 & 0.0245 & 0.7316 & 0.2316 & 0.0368 \\
\hline & 200 & 0.0500 & 0.7125 & 0.2125 & 0.0750 \\
\hline & 300 & 0.0759 & 0.6930 & 0.1930 & 0.1139 \\
\hline & 400 & 0.0990 & 0.6757 & 0.1757 & 0.1485 \\
\hline & 500 & 0.1185 & 0.6611 & 0.1611 & 0.1777 \\
\hline & 600 & 0.1346 & 0.6491 & 0.1491 & 0.2018 \\
\hline \multirow{6}{*}{ 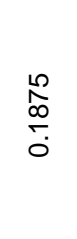 } & 100 & 0.0260 & 0.7083 & 0.2538 & 0.0379 \\
\hline & 200 & 0.0532 & 0.6886 & 0.2340 & 0.0774 \\
\hline & 300 & 0.0809 & 0.6684 & 0.2139 & 0.1177 \\
\hline & 400 & 0.1058 & 0.6504 & 0.1958 & 0.1538 \\
\hline & 500 & 0.1268 & 0.6351 & 0.1805 & 0.1844 \\
\hline & 600 & 0.1442 & 0.6224 & 0.1679 & 0.2097 \\
\hline \multirow{6}{*}{$\begin{array}{l}\text { Oे } \\
\text { N̦ } \\
0\end{array}$} & 100 & 0.0269 & 0.6951 & 0.2665 & 0.0384 \\
\hline & 200 & 0.0550 & 0.6750 & 0.2464 & 0.0786 \\
\hline & 300 & 0.0838 & 0.6544 & 0.2259 & 0.1197 \\
\hline & 400 & 0.1096 & 0.6360 & 0.2074 & 0.1566 \\
\hline & 500 & 0.1315 & 0.6204 & 0.1918 & 0.1878 \\
\hline & 600 & 0.1497 & 0.6074 & 0.1788 & 0.2138 \\
\hline
\end{tabular}




\section{Appendix H (Continued) Compilation of Thermodynamic Data for DME Hydrolysis}

\begin{tabular}{|c|c|c|c|c|c|}
\hline \multirow{2}{*}{$\mathrm{S} / \mathrm{C}$} & \multirow{2}{*}{$\begin{array}{c}\text { Temperature } \\
\left({ }^{\circ} \mathrm{C}\right)\end{array}$} & \multirow{2}{*}{$\begin{array}{c}\text { DME } \\
\text { Conversion }\end{array}$} & \multicolumn{3}{|c|}{ Fractional Concentration: Wet Basis } \\
\hline & & & $\mathrm{CH}_{3} \mathrm{OCH}_{3}$ & $\mathrm{H}_{2} \mathrm{O}$ & $\mathrm{CH}_{3} \mathrm{OH}$ \\
\hline \multirow{6}{*}{ 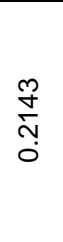 } & 100 & 0.0279 & 0.6805 & 0.2805 & 0.0390 \\
\hline & 200 & 0.0570 & 0.6601 & 0.2601 & 0.0799 \\
\hline & 300 & 0.0870 & 0.6391 & 0.2391 & 0.1217 \\
\hline & 400 & 0.1138 & 0.6203 & 0.2203 & 0.1594 \\
\hline & 500 & 0.1367 & 0.6043 & 0.2043 & 0.1913 \\
\hline & 600 & 0.1557 & 0.5910 & 0.1910 & 0.2180 \\
\hline \multirow{6}{*}{ 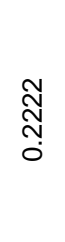 } & 100 & 0.0284 & 0.6726 & 0.2880 & 0.0393 \\
\hline & 200 & 0.0581 & 0.6521 & 0.2674 & 0.0805 \\
\hline & 300 & 0.0887 & 0.6309 & 0.2463 & 0.1228 \\
\hline & 400 & 0.1161 & 0.6119 & 0.2273 & 0.1608 \\
\hline & 500 & 0.1395 & 0.5957 & 0.2111 & 0.1931 \\
\hline & 600 & 0.1590 & 0.5822 & 0.1976 & 0.2201 \\
\hline \multirow{6}{*}{ 客 } & 100 & 0.0302 & 0.6466 & 0.3132 & 0.0402 \\
\hline & 200 & 0.0618 & 0.6255 & 0.2921 & 0.0824 \\
\hline & 300 & 0.0944 & 0.6038 & 0.2704 & 0.1258 \\
\hline & 400 & 0.1237 & 0.5842 & 0.2508 & 0.1650 \\
\hline & 500 & 0.1488 & 0.5674 & 0.2341 & 0.1985 \\
\hline & 600 & 0.1699 & 0.5534 & 0.2201 & 0.2265 \\
\hline \multirow{6}{*}{$\underset{\substack{\infty \\
\multirow{N}{N}{0}\\
0}}{ }$} & 100 & 0.0318 & 0.6224 & 0.3367 & 0.0409 \\
\hline & 200 & 0.0653 & 0.6009 & 0.3152 & 0.0839 \\
\hline & 300 & 0.0997 & 0.5787 & 0.2930 & 0.1282 \\
\hline & 400 & 0.1309 & 0.5587 & 0.2730 & 0.1683 \\
\hline & 500 & 0.1576 & 0.5415 & 0.2558 & 0.2027 \\
\hline & 600 & 0.1800 & 0.5271 & 0.2414 & 0.2315 \\
\hline \multirow{6}{*}{$\begin{array}{c}\hat{n} \\
\stackrel{\infty}{N} \\
0\end{array}$} & 100 & 0.0323 & 0.6158 & 0.3431 & 0.0411 \\
\hline & 200 & 0.0662 & 0.5942 & 0.3215 & 0.0843 \\
\hline & 300 & 0.1012 & 0.5719 & 0.2992 & 0.1288 \\
\hline & 400 & 0.1329 & 0.5518 & 0.2791 & 0.1691 \\
\hline & 500 & 0.1600 & 0.5345 & 0.2618 & 0.2037 \\
\hline & 600 & 0.1828 & 0.5200 & 0.2473 & 0.2327 \\
\hline \multirow{6}{*}{$\begin{array}{l}\text { ৪ } \\
\text { o } \\
0 \\
0\end{array}$} & 100 & 0.0331 & 0.6043 & 0.3543 & 0.0413 \\
\hline & 200 & 0.0679 & 0.5826 & 0.3326 & 0.0849 \\
\hline & 300 & 0.1038 & 0.5601 & 0.3101 & 0.1298 \\
\hline & 400 & 0.1364 & 0.5398 & 0.2898 & 0.1705 \\
\hline & 500 & 0.1643 & 0.5223 & 0.2723 & 0.2054 \\
\hline & 600 & 0.1877 & 0.5077 & 0.2577 & 0.2347 \\
\hline \multirow{6}{*}{$\stackrel{\stackrel{L}{7}}{\underset{m}{0}}$} & 100 & 0.0338 & 0.5946 & 0.3638 & 0.0416 \\
\hline & 200 & 0.0693 & 0.5727 & 0.3420 & 0.0853 \\
\hline & 300 & 0.1061 & 0.5501 & 0.3194 & 0.1305 \\
\hline & 400 & 0.1393 & 0.5296 & 0.2989 & 0.1715 \\
\hline & 500 & 0.1679 & 0.5121 & 0.2813 & 0.2067 \\
\hline & 600 & 0.1919 & 0.4973 & 0.2665 & 0.2362 \\
\hline
\end{tabular}




\section{Appendix H (Continued) Compilation of Thermodynamic Data for DME Hydrolysis}

\begin{tabular}{|c|c|c|c|c|c|}
\hline \multirow{2}{*}{$\mathrm{S} / \mathrm{C}$} & \multirow{2}{*}{$\begin{array}{c}\text { Temperature } \\
\left({ }^{\circ} \mathrm{C}\right) \\
\end{array}$} & \multirow{2}{*}{$\begin{array}{c}\text { DME } \\
\text { Conversion } \\
\end{array}$} & \multicolumn{3}{|c|}{ Fractional Concentration: Wet Basis } \\
\hline & & & $\mathrm{CH}_{3} \mathrm{OCH}_{3}$ & $\mathrm{H}_{2} \mathrm{O}$ & $\mathrm{CH}_{3} \mathrm{OH}$ \\
\hline \multirow{6}{*}{ 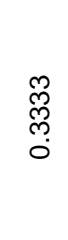 } & 100 & 0.0349 & 0.5791 & 0.3791 & 0.0419 \\
\hline & 200 & 0.0716 & 0.5570 & 0.3570 & 0.0860 \\
\hline & 300 & 0.1097 & 0.5342 & 0.3342 & 0.1316 \\
\hline & 400 & 0.1441 & 0.5135 & 0.3135 & 0.1730 \\
\hline & 500 & 0.1738 & 0.4957 & 0.2957 & 0.2085 \\
\hline & 600 & 0.1987 & 0.4808 & 0.2808 & 0.2384 \\
\hline \multirow{6}{*}{$\begin{array}{l}\stackrel{8}{\circ} \\
\text { ल्p } \\
\stackrel{0}{0}\end{array}$} & 100 & 0.0358 & 0.5672 & 0.3907 & 0.0421 \\
\hline & 200 & 0.0734 & 0.5450 & 0.3686 & 0.0864 \\
\hline & 300 & 0.1124 & 0.5221 & 0.3456 & 0.1323 \\
\hline & 400 & 0.1478 & 0.5013 & 0.3248 & 0.1739 \\
\hline & 500 & 0.1783 & 0.4834 & 0.3069 & 0.2097 \\
\hline & 600 & 0.2039 & 0.4683 & 0.2918 & 0.2399 \\
\hline \multirow{6}{*}{$\begin{array}{l}\underset{H}{\hat{N}} \\
\stackrel{m}{0} \\
\stackrel{0}{0}\end{array}$} & 100 & 0.0361 & 0.5623 & 0.3956 & 0.0421 \\
\hline & 200 & 0.0742 & 0.5401 & 0.3734 & 0.0866 \\
\hline & 300 & 0.1136 & 0.5171 & 0.3504 & 0.1326 \\
\hline & 400 & 0.1494 & 0.4962 & 0.3295 & 0.1743 \\
\hline & 500 & 0.1802 & 0.4782 & 0.3116 & 0.2102 \\
\hline & 600 & 0.2061 & 0.4631 & 0.2964 & 0.2404 \\
\hline \multirow{6}{*}{$\begin{array}{l}\stackrel{0}{\circ} \\
\stackrel{n}{m} \\
0\end{array}$} & 100 & 0.0370 & 0.5503 & 0.4074 & 0.0423 \\
\hline & 200 & 0.0761 & 0.5280 & 0.3851 & 0.0869 \\
\hline & 300 & 0.1165 & 0.5049 & 0.3620 & 0.1331 \\
\hline & 400 & 0.1532 & 0.4839 & 0.3410 & 0.1751 \\
\hline & 500 & 0.1848 & 0.4658 & 0.3230 & 0.2112 \\
\hline & 600 & 0.2114 & 0.4506 & 0.3077 & 0.2416 \\
\hline \multirow{6}{*}{ 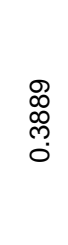 } & 100 & 0.0377 & 0.5413 & 0.4163 & 0.0424 \\
\hline & 200 & 0.0775 & 0.5189 & 0.3939 & 0.0872 \\
\hline & 300 & 0.1187 & 0.4957 & 0.3707 & 0.1335 \\
\hline & 400 & 0.1561 & 0.4747 & 0.3497 & 0.1756 \\
\hline & 500 & 0.1883 & 0.4566 & 0.3316 & 0.2119 \\
\hline & 600 & 0.2155 & 0.4413 & 0.3163 & 0.2424 \\
\hline \multirow{6}{*}{ 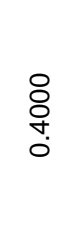 } & 100 & 0.0382 & 0.5343 & 0.4232 & 0.0425 \\
\hline & 200 & 0.0786 & 0.5119 & 0.4008 & 0.0873 \\
\hline & 300 & 0.1204 & 0.4887 & 0.3776 & 0.1338 \\
\hline & 400 & 0.1584 & 0.4676 & 0.3565 & 0.1760 \\
\hline & 500 & 0.1911 & 0.4494 & 0.3383 & 0.2123 \\
\hline & 600 & 0.2187 & 0.4341 & 0.3230 & 0.2430 \\
\hline \multirow{6}{*}{$\begin{array}{l}\hat{\theta} \\
\dot{y} \\
\dot{t} \\
0\end{array}$} & 100 & 0.0390 & 0.5242 & 0.4333 & 0.0426 \\
\hline & 200 & 0.0802 & 0.5017 & 0.4108 & 0.0875 \\
\hline & 300 & 0.1229 & 0.4784 & 0.3875 & 0.1341 \\
\hline & 400 & 0.1617 & 0.4572 & 0.3663 & 0.1764 \\
\hline & 500 & 0.1951 & 0.4390 & 0.3481 & 0.2129 \\
\hline & 600 & 0.2233 & 0.4236 & 0.3327 & 0.2436 \\
\hline
\end{tabular}




\section{Appendix H (Continued) Compilation of Thermodynamic Data for DME Hydrolysis}

\begin{tabular}{|c|c|c|c|c|c|}
\hline \multirow{2}{*}{$\mathrm{S} / \mathrm{C}$} & \multirow{2}{*}{$\begin{array}{c}\text { Temperature } \\
\left({ }^{\circ} \mathrm{C}\right)\end{array}$} & \multirow{2}{*}{$\begin{array}{c}\text { DME } \\
\text { Conversion }\end{array}$} & \multicolumn{3}{|c|}{ Fractional Concentration: Wet Basis } \\
\hline & & & $\mathrm{CH}_{3} \mathrm{OCH}_{3}$ & $\mathrm{H}_{2} \mathrm{O}$ & $\mathrm{CH}_{3} \mathrm{OH}$ \\
\hline \multirow{6}{*}{ 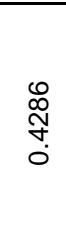 } & 100 & 0.0396 & 0.5171 & 0.4402 & 0.0426 \\
\hline & 200 & 0.0814 & 0.4946 & 0.4177 & 0.0876 \\
\hline & 300 & 0.1247 & 0.4713 & 0.3944 & 0.1343 \\
\hline & 400 & 0.1641 & 0.4501 & 0.3732 & 0.1767 \\
\hline & 500 & 0.1980 & 0.4319 & 0.3549 & 0.2132 \\
\hline & 600 & 0.2266 & 0.4165 & 0.3395 & 0.2440 \\
\hline \multirow{6}{*}{ 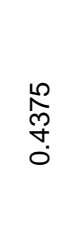 } & 100 & 0.0400 & 0.5120 & 0.4453 & 0.0427 \\
\hline & 200 & 0.0822 & 0.4895 & 0.4228 & 0.0877 \\
\hline & 300 & 0.1260 & 0.4661 & 0.3995 & 0.1344 \\
\hline & 400 & 0.1658 & 0.4449 & 0.3782 & 0.1768 \\
\hline & 500 & 0.2001 & 0.4266 & 0.3600 & 0.2134 \\
\hline & 600 & 0.2290 & 0.4112 & 0.3445 & 0.2443 \\
\hline \multirow{6}{*}{ 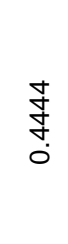 } & 100 & 0.0403 & 0.5081 & 0.4492 & 0.0427 \\
\hline & 200 & 0.0829 & 0.4855 & 0.4267 & 0.0878 \\
\hline & 300 & 0.1270 & 0.4622 & 0.4034 & 0.1345 \\
\hline & 400 & 0.1671 & 0.4409 & 0.3821 & 0.1769 \\
\hline & 500 & 0.2017 & 0.4226 & 0.3638 & 0.2135 \\
\hline & 600 & 0.2308 & 0.4072 & 0.3484 & 0.2444 \\
\hline \multirow{6}{*}{ 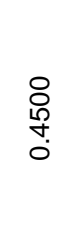 } & 100 & 0.0406 & 0.5050 & 0.4523 & 0.0427 \\
\hline & 200 & 0.0834 & 0.4824 & 0.4298 & 0.0878 \\
\hline & 300 & 0.1278 & 0.4591 & 0.4064 & 0.1345 \\
\hline & 400 & 0.1682 & 0.4378 & 0.3852 & 0.1770 \\
\hline & 500 & 0.2029 & 0.4195 & 0.3669 & 0.2136 \\
\hline & 600 & 0.2323 & 0.4041 & 0.3514 & 0.2445 \\
\hline \multirow{6}{*}{$\begin{array}{l}8 \\
\text { ஜ } \\
\text { !n } \\
0\end{array}$} & 100 & 0.0428 & 0.4786 & 0.4786 & 0.0428 \\
\hline & 200 & 0.0879 & 0.4560 & 0.4560 & 0.0879 \\
\hline & 300 & 0.1347 & 0.4326 & 0.4326 & 0.1347 \\
\hline & 400 & 0.1773 & 0.4113 & 0.4113 & 0.1773 \\
\hline & 500 & 0.2140 & 0.3930 & 0.3930 & 0.2140 \\
\hline & 600 & 0.2450 & 0.3775 & 0.3775 & 0.2450 \\
\hline \multirow{6}{*}{$\begin{array}{l}0 \\
\text { Lొ } \\
\text { م⿱ } \\
0 \\
0\end{array}$} & 100 & 0.0451 & 0.4523 & 0.5050 & 0.0427 \\
\hline & 200 & 0.0927 & 0.4298 & 0.4824 & 0.0878 \\
\hline & 300 & 0.1420 & 0.4064 & 0.4591 & 0.1345 \\
\hline & 400 & 0.1869 & 0.3852 & 0.4378 & 0.1770 \\
\hline & 500 & 0.2255 & 0.3669 & 0.4195 & 0.2136 \\
\hline & 600 & 0.2581 & 0.3514 & 0.4041 & 0.2445 \\
\hline \multirow{6}{*}{$\begin{array}{l}\stackrel{L}{N} \\
\text { Lొ } \\
0\end{array}$} & 100 & 0.0454 & 0.4492 & 0.5081 & 0.0427 \\
\hline & 200 & 0.0932 & 0.4267 & 0.4855 & 0.0878 \\
\hline & 300 & 0.1429 & 0.4034 & 0.4622 & 0.1345 \\
\hline & 400 & 0.1880 & 0.3821 & 0.4409 & 0.1769 \\
\hline & 500 & 0.2269 & 0.3638 & 0.4226 & 0.2135 \\
\hline & 600 & 0.2597 & 0.3484 & 0.4072 & 0.2444 \\
\hline
\end{tabular}




\section{Appendix H (Continued) Compilation of Thermodynamic Data for DME Hydrolysis}

\begin{tabular}{|c|c|c|c|c|c|}
\hline \multirow{2}{*}{$\mathrm{S} / \mathrm{C}$} & \multirow{2}{*}{$\begin{array}{c}\text { Temperature } \\
\left({ }^{\circ} \mathrm{C}\right)\end{array}$} & \multirow{2}{*}{$\begin{array}{c}\text { DME } \\
\text { Conversion }\end{array}$} & \multicolumn{3}{|c|}{ Fractional Concentration: Wet Basis } \\
\hline & & & $\mathrm{CH}_{3} \mathrm{OCH}_{3}$ & $\mathrm{H}_{2} \mathrm{O}$ & $\mathrm{CH}_{3} \mathrm{OH}$ \\
\hline \multirow{6}{*}{ 范 } & 100 & 0.0457 & 0.4453 & 0.5120 & 0.0427 \\
\hline & 200 & 0.0940 & 0.4228 & 0.4895 & 0.0877 \\
\hline & 300 & 0.1440 & 0.3995 & 0.4661 & 0.1344 \\
\hline & 400 & 0.1895 & 0.3782 & 0.4449 & 0.1768 \\
\hline & 500 & 0.2286 & 0.3600 & 0.4266 & 0.2134 \\
\hline & 600 & 0.2617 & 0.3445 & 0.4112 & 0.2443 \\
\hline \multirow{6}{*}{$\begin{array}{l}\prod_{\mathscr{N}} \\
\text { Lొ } \\
0 \\
0\end{array}$} & 100 & 0.0462 & 0.4402 & 0.5171 & 0.0426 \\
\hline & 200 & 0.0949 & 0.4177 & 0.4946 & 0.0876 \\
\hline & 300 & 0.1455 & 0.3944 & 0.4713 & 0.1343 \\
\hline & 400 & 0.1914 & 0.3732 & 0.4501 & 0.1767 \\
\hline & 500 & 0.2310 & 0.3549 & 0.4319 & 0.2132 \\
\hline & 600 & 0.2643 & 0.3395 & 0.4165 & 0.2440 \\
\hline \multirow{6}{*}{$\begin{array}{l}8 \\
\varnothing \\
0 \\
0\end{array}$} & 100 & 0.0468 & 0.4333 & 0.5242 & 0.0426 \\
\hline & 200 & 0.0963 & 0.4108 & 0.5017 & 0.0875 \\
\hline & 300 & 0.1475 & 0.3875 & 0.4784 & 0.1341 \\
\hline & 400 & 0.1941 & 0.3663 & 0.4572 & 0.1764 \\
\hline & 500 & 0.2342 & 0.3481 & 0.4390 & 0.2129 \\
\hline & 600 & 0.2680 & 0.3327 & 0.4236 & 0.2436 \\
\hline \multirow{6}{*}{ 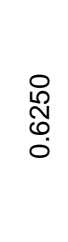 } & 100 & 0.0478 & 0.4232 & 0.5343 & 0.0425 \\
\hline & 200 & 0.0982 & 0.4008 & 0.5119 & 0.0873 \\
\hline & 300 & 0.1505 & 0.3776 & 0.4887 & 0.1338 \\
\hline & 400 & 0.1980 & 0.3565 & 0.4676 & 0.1760 \\
\hline & 500 & 0.2389 & 0.3383 & 0.4494 & 0.2123 \\
\hline & 600 & 0.2733 & 0.3230 & 0.4341 & 0.2430 \\
\hline \multirow{6}{*}{ 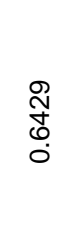 } & 100 & 0.0485 & 0.4163 & 0.5413 & 0.0424 \\
\hline & 200 & 0.0996 & 0.3939 & 0.5189 & 0.0872 \\
\hline & 300 & 0.1526 & 0.3707 & 0.4957 & 0.1335 \\
\hline & 400 & 0.2007 & 0.3497 & 0.4747 & 0.1756 \\
\hline & 500 & 0.2421 & 0.3316 & 0.4566 & 0.2119 \\
\hline & 600 & 0.2771 & 0.3163 & 0.4413 & 0.2424 \\
\hline \multirow{6}{*}{$\begin{array}{l}\hat{0} \\
\emptyset \\
0 \\
0\end{array}$} & 100 & 0.0494 & 0.4074 & 0.5503 & 0.0423 \\
\hline & 200 & 0.1014 & 0.3851 & 0.5280 & 0.0869 \\
\hline & 300 & 0.1553 & 0.3620 & 0.5049 & 0.1331 \\
\hline & 400 & 0.2043 & 0.3410 & 0.4839 & 0.1751 \\
\hline & 500 & 0.2464 & 0.3230 & 0.4658 & 0.2112 \\
\hline & 600 & 0.2819 & 0.3077 & 0.4506 & 0.2417 \\
\hline \multirow{6}{*}{$\begin{array}{l}8 \\
\stackrel{8}{1} \\
0 \\
0\end{array}$} & 100 & 0.0506 & 0.3956 & 0.5623 & 0.0421 \\
\hline & 200 & 0.1039 & 0.3734 & 0.5400 & 0.0866 \\
\hline & 300 & 0.1591 & 0.3504 & 0.5171 & 0.1326 \\
\hline & 400 & 0.2092 & 0.3295 & 0.4962 & 0.1743 \\
\hline & 500 & 0.2522 & 0.3116 & 0.4782 & 0.2102 \\
\hline & 600 & 0.2885 & 0.2964 & 0.4631 & 0.2404 \\
\hline
\end{tabular}




\section{Appendix H (Continued) Compilation of Thermodynamic Data for DME Hydrolysis}

\begin{tabular}{|c|c|c|c|c|c|}
\hline \multirow{2}{*}{$\mathrm{S} / \mathrm{C}$} & \multirow{2}{*}{$\begin{array}{c}\text { Temperature } \\
\left({ }^{\circ} \mathrm{C}\right)\end{array}$} & \multirow{2}{*}{$\begin{array}{c}\text { DME } \\
\text { Conversion }\end{array}$} & \multicolumn{3}{|c|}{ Fractional Concentration: Wet Basis } \\
\hline & & & $\mathrm{CH}_{3} \mathrm{OCH}_{3}$ & $\mathrm{H}_{2} \mathrm{O}$ & $\mathrm{CH}_{3} \mathrm{OH}$ \\
\hline \multirow{6}{*}{ } & 100 & 0.0511 & 0.3907 & 0.5672 & 0.0421 \\
\hline & 200 & 0.1049 & 0.3686 & 0.5450 & 0.0864 \\
\hline & 300 & 0.1606 & 0.3456 & 0.5221 & 0.1323 \\
\hline & 400 & 0.2112 & 0.3248 & 0.5013 & 0.1739 \\
\hline & 500 & 0.2547 & 0.3069 & 0.4834 & 0.2097 \\
\hline & 600 & 0.2913 & 0.2918 & 0.4683 & 0.2399 \\
\hline \multirow{6}{*}{ 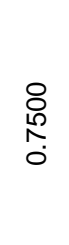 } & 100 & 0.0523 & 0.3791 & 0.5791 & 0.0419 \\
\hline & 200 & 0.1075 & 0.3570 & 0.5570 & 0.0860 \\
\hline & 300 & 0.1645 & 0.3342 & 0.5342 & 0.1316 \\
\hline & 400 & 0.2162 & 0.3135 & 0.5135 & 0.1730 \\
\hline & 500 & 0.2606 & 0.2957 & 0.4957 & 0.2085 \\
\hline & 600 & 0.2980 & 0.2808 & 0.4808 & 0.2384 \\
\hline \multirow{6}{*}{$\begin{array}{l}8 \\
\varnothing \\
\infty \\
0 \\
0\end{array}$} & 100 & 0.0540 & 0.3638 & 0.5946 & 0.0416 \\
\hline & 200 & 0.1109 & 0.3420 & 0.5727 & 0.0853 \\
\hline & 300 & 0.1697 & 0.3193 & 0.5501 & 0.1305 \\
\hline & 400 & 0.2230 & 0.2989 & 0.5296 & 0.1715 \\
\hline & 500 & 0.2687 & 0.2813 & 0.5121 & 0.2067 \\
\hline & 600 & 0.3071 & 0.2665 & 0.4973 & 0.2362 \\
\hline \multirow{6}{*}{$\begin{array}{c}\underset{m}{m} \\
\infty \\
0 \\
0\end{array}$} & 100 & 0.0551 & 0.3543 & 0.6043 & 0.0414 \\
\hline & 200 & 0.1132 & 0.3326 & 0.5826 & 0.0849 \\
\hline & 300 & 0.1731 & 0.3101 & 0.5601 & 0.1298 \\
\hline & 400 & 0.2273 & 0.2898 & 0.5398 & 0.1705 \\
\hline & 500 & 0.2738 & 0.2723 & 0.5223 & 0.2054 \\
\hline & 600 & 0.3129 & 0.2577 & 0.5077 & 0.2347 \\
\hline \multirow{6}{*}{ 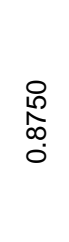 } & 100 & 0.0565 & 0.3431 & 0.6158 & 0.0411 \\
\hline & 200 & 0.1159 & 0.3215 & 0.5942 & 0.0843 \\
\hline & 300 & 0.1772 & 0.2992 & 0.5719 & 0.1288 \\
\hline & 400 & 0.2326 & 0.2791 & 0.5518 & 0.1692 \\
\hline & 500 & 0.2801 & 0.2618 & 0.5345 & 0.2037 \\
\hline & 600 & 0.3200 & 0.2473 & 0.5200 & 0.2327 \\
\hline \multirow{6}{*}{$\begin{array}{l}8 \\
\text { ঃ } \\
\\
0\end{array}$} & 100 & 0.0573 & 0.3367 & 0.6224 & 0.0409 \\
\hline & 200 & 0.1175 & 0.3152 & 0.6009 & 0.0839 \\
\hline & 300 & 0.1796 & 0.2930 & 0.5787 & 0.1283 \\
\hline & 400 & 0.2357 & 0.2730 & 0.5587 & 0.1683 \\
\hline & 500 & 0.2837 & 0.2558 & 0.5415 & 0.2027 \\
\hline & 600 & 0.3241 & 0.2414 & 0.5271 & 0.2315 \\
\hline \multirow{6}{*}{ 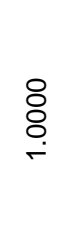 } & 100 & 0.0603 & 0.3132 & 0.6466 & 0.0402 \\
\hline & 200 & 0.1236 & 0.2921 & 0.6255 & 0.0824 \\
\hline & 300 & 0.1888 & 0.2704 & 0.6037 & 0.1258 \\
\hline & 400 & 0.2475 & 0.2508 & 0.5842 & 0.1650 \\
\hline & 500 & 0.2977 & 0.2341 & 0.5674 & 0.1985 \\
\hline & 600 & 0.3397 & 0.2201 & 0.5534 & 0.2265 \\
\hline
\end{tabular}




\section{Appendix H (Continued) Compilation of Thermodynamic Data for DME Hydrolysis}

\begin{tabular}{|c|c|c|c|c|c|}
\hline \multirow{2}{*}{$\mathrm{S} / \mathrm{C}$} & \multirow{2}{*}{$\begin{array}{c}\text { Temperature } \\
\left({ }^{\circ} \mathrm{C}\right)\end{array}$} & \multirow{2}{*}{$\begin{array}{c}\text { DME } \\
\text { Conversion }\end{array}$} & \multicolumn{3}{|c|}{ Fractional Concentration: Wet Basis } \\
\hline & & & $\mathrm{CH}_{3} \mathrm{OCH}_{3}$ & $\mathrm{H}_{2} \mathrm{O}$ & $\mathrm{CH}_{3} \mathrm{OH}$ \\
\hline \multirow{6}{*}{ 怘 } & 100 & 0.0639 & 0.2880 & 0.6726 & 0.0393 \\
\hline & 200 & 0.1308 & 0.2674 & 0.6520 & 0.0805 \\
\hline & 300 & 0.1995 & 0.2463 & 0.6309 & 0.1228 \\
\hline & 400 & 0.2613 & 0.2273 & 0.6119 & 0.1608 \\
\hline & 500 & 0.3138 & 0.2111 & 0.5957 & 0.1931 \\
\hline & 600 & 0.3577 & 0.1976 & 0.5822 & 0.2201 \\
\hline \multirow{6}{*}{$\begin{array}{l}\hat{o} \\
\stackrel{\leftrightarrow}{\rightarrow} \\
\rightarrow\end{array}$} & 100 & 0.0651 & 0.2805 & 0.6805 & 0.0390 \\
\hline & 200 & 0.1331 & 0.2601 & 0.6601 & 0.0799 \\
\hline & 300 & 0.2029 & 0.2391 & 0.6391 & 0.1218 \\
\hline & 400 & 0.2656 & 0.2203 & 0.6203 & 0.1594 \\
\hline & 500 & 0.3189 & 0.2043 & 0.6043 & 0.1914 \\
\hline & 600 & 0.3634 & 0.1910 & 0.5910 & 0.2180 \\
\hline \multirow{6}{*}{ 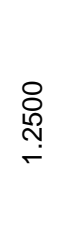 } & 100 & 0.0673 & 0.2665 & 0.6951 & 0.0385 \\
\hline & 200 & 0.1376 & 0.2464 & 0.6750 & 0.0786 \\
\hline & 300 & 0.2095 & 0.2258 & 0.6544 & 0.1197 \\
\hline & 400 & 0.2740 & 0.2074 & 0.6360 & 0.1566 \\
\hline & 500 & 0.3287 & 0.1918 & 0.6204 & 0.1878 \\
\hline & 600 & 0.3742 & 0.1788 & 0.6074 & 0.2138 \\
\hline \multirow{6}{*}{ 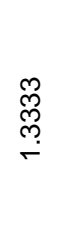 } & 100 & 0.0695 & 0.2538 & 0.7083 & 0.0379 \\
\hline & 200 & 0.1419 & 0.2340 & 0.6886 & 0.0774 \\
\hline & 300 & 0.2159 & 0.2138 & 0.6684 & 0.1178 \\
\hline & 400 & 0.2820 & 0.1958 & 0.6504 & 0.1538 \\
\hline & 500 & 0.3380 & 0.1805 & 0.6351 & 0.1844 \\
\hline & 600 & 0.3845 & 0.1679 & 0.6224 & 0.2098 \\
\hline \multirow{6}{*}{ 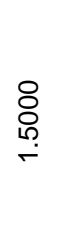 } & 100 & 0.0736 & 0.2316 & 0.7316 & 0.0368 \\
\hline & 200 & 0.1501 & 0.2125 & 0.7125 & 0.0750 \\
\hline & 300 & 0.2279 & 0.1930 & 0.6930 & 0.1139 \\
\hline & 400 & 0.2971 & 0.1757 & 0.6757 & 0.1486 \\
\hline & 500 & 0.3555 & 0.1611 & 0.6611 & 0.1777 \\
\hline & 600 & 0.4037 & 0.1491 & 0.6491 & 0.2019 \\
\hline \multirow{6}{*}{$\begin{array}{l}\hat{\theta} \\
\mathscr{0} \\
\ddot{\bullet}\end{array}$} & 100 & 0.0775 & 0.2129 & 0.7514 & 0.0358 \\
\hline & 200 & 0.1577 & 0.1944 & 0.7328 & 0.0728 \\
\hline & 300 & 0.2390 & 0.1756 & 0.7141 & 0.1103 \\
\hline & 400 & 0.3110 & 0.1590 & 0.6975 & 0.1436 \\
\hline & 500 & 0.3715 & 0.1450 & 0.6835 & 0.1715 \\
\hline & 600 & 0.4212 & 0.1336 & 0.6720 & 0.1944 \\
\hline \multirow{6}{*}{ 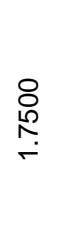 } & 100 & 0.0793 & 0.2046 & 0.7602 & 0.0353 \\
\hline & 200 & 0.1613 & 0.1864 & 0.7419 & 0.0717 \\
\hline & 300 & 0.2443 & 0.1679 & 0.7235 & 0.1086 \\
\hline & 400 & 0.3176 & 0.1516 & 0.7072 & 0.1412 \\
\hline & 500 & 0.3790 & 0.1380 & 0.6935 & 0.1685 \\
\hline & 600 & 0.4295 & 0.1268 & 0.6823 & 0.1909 \\
\hline
\end{tabular}




\section{Appendix H (Continued) Compilation of Thermodynamic Data for DME Hydrolysis}

\begin{tabular}{|c|c|c|c|c|c|}
\hline \multirow{2}{*}{$\mathrm{S} / \mathrm{C}$} & \multirow{2}{*}{$\begin{array}{c}\text { Temperature } \\
\left({ }^{\circ} \mathrm{C}\right)\end{array}$} & \multirow{2}{*}{$\begin{array}{c}\text { DME } \\
\text { Conversion }\end{array}$} & \multicolumn{3}{|c|}{ Fractional Concentration: Wet Basis } \\
\hline & & & $\mathrm{CH}_{3} \mathrm{OCH}_{3}$ & $\mathrm{H}_{2} \mathrm{O}$ & $\mathrm{CH}_{3} \mathrm{OH}$ \\
\hline \multirow{6}{*}{$\begin{array}{l}\text { \& } \\
\text { ¿ } \\
\text { ì }\end{array}$} & 100 & 0.0846 & 0.1831 & 0.7831 & 0.0338 \\
\hline & 200 & 0.1717 & 0.1657 & 0.7657 & 0.0687 \\
\hline & 300 & 0.2593 & 0.1481 & 0.7481 & 0.1037 \\
\hline & 400 & 0.3362 & 0.1328 & 0.7328 & 0.1345 \\
\hline & 500 & 0.4001 & 0.1200 & 0.7200 & 0.1601 \\
\hline & 600 & 0.4523 & 0.1095 & 0.7095 & 0.1809 \\
\hline \multirow{6}{*}{$\begin{array}{l}\text { \& } \\
\stackrel{N}{N} \\
\stackrel{N}{N}\end{array}$} & 100 & 0.0896 & 0.1655 & 0.8019 & 0.0326 \\
\hline & 200 & 0.1813 & 0.1489 & 0.7852 & 0.0659 \\
\hline & 300 & 0.2730 & 0.1322 & 0.7685 & 0.0993 \\
\hline & 400 & 0.3531 & 0.1176 & 0.7540 & 0.1284 \\
\hline & 500 & 0.4192 & 0.1056 & 0.7420 & 0.1524 \\
\hline & 600 & 0.4728 & 0.0959 & 0.7322 & 0.1719 \\
\hline \multirow{6}{*}{$\begin{array}{l}\text { ठ } \\
\text { ஸn } \\
\text { N }\end{array}$} & 100 & 0.0942 & 0.1510 & 0.8176 & 0.0314 \\
\hline & 200 & 0.1903 & 0.1350 & 0.8016 & 0.0634 \\
\hline & 300 & 0.2858 & 0.1190 & 0.7857 & 0.0953 \\
\hline & 400 & 0.3686 & 0.1052 & 0.7719 & 0.1229 \\
\hline & 500 & 0.4366 & 0.0939 & 0.7606 & 0.1455 \\
\hline & 600 & 0.4914 & 0.0848 & 0.7514 & 0.1638 \\
\hline \multirow{6}{*}{$\begin{array}{l}\text { ¿ } \\
\text { ठ } \\
\dot{m}\end{array}$} & 100 & 0.1028 & 0.1282 & 0.8425 & 0.0294 \\
\hline & 200 & 0.2067 & 0.1133 & 0.8276 & 0.0591 \\
\hline & 300 & 0.3089 & 0.0987 & 0.8130 & 0.0883 \\
\hline & 400 & 0.3964 & 0.0862 & 0.8005 & 0.1133 \\
\hline & 500 & 0.4674 & 0.0761 & 0.7904 & 0.1335 \\
\hline & 600 & 0.5239 & 0.0680 & 0.7823 & 0.1497 \\
\hline \multirow{6}{*}{$\begin{array}{l}8 \\
\text { ठํ } \\
\text { மூ } \\
\text { m. }\end{array}$} & 100 & 0.1107 & 0.1112 & 0.8612 & 0.0277 \\
\hline & 200 & 0.2215 & 0.0973 & 0.8473 & 0.0554 \\
\hline & 300 & 0.3294 & 0.0838 & 0.8338 & 0.0824 \\
\hline & 400 & 0.4208 & 0.0724 & 0.8224 & 0.1052 \\
\hline & 500 & 0.4940 & 0.0632 & 0.8132 & 0.1235 \\
\hline & 600 & 0.5517 & 0.0560 & 0.8060 & 0.1379 \\
\hline \multirow{6}{*}{$\begin{array}{l}8 \\
8 \\
\text { ¿ }\end{array}$} & 100 & 0.1179 & 0.0980 & 0.8758 & 0.0262 \\
\hline & 200 & 0.2350 & 0.0850 & 0.8628 & 0.0522 \\
\hline & 300 & 0.3479 & 0.0725 & 0.8502 & 0.0773 \\
\hline & 400 & 0.4425 & 0.0619 & 0.8397 & 0.0983 \\
\hline & 500 & 0.5174 & 0.0536 & 0.8314 & 0.1150 \\
\hline & 600 & 0.5758 & 0.0471 & 0.8249 & 0.1280 \\
\hline \multirow{6}{*}{$\begin{array}{l}8 \\
\text { ஜn } \\
\text { டீ }\end{array}$} & 100 & 0.1246 & 0.0875 & 0.8875 & 0.0249 \\
\hline & 200 & 0.2475 & 0.0753 & 0.8753 & 0.0495 \\
\hline & 300 & 0.3648 & 0.0635 & 0.8635 & 0.0730 \\
\hline & 400 & 0.4620 & 0.0538 & 0.8538 & 0.0924 \\
\hline & 500 & 0.5382 & 0.0462 & 0.8462 & 0.1076 \\
\hline & 600 & 0.5971 & 0.0403 & 0.8403 & 0.1194 \\
\hline \multirow{6}{*}{$\begin{array}{l}8 \\
8 \\
\circ \\
\text { ம }\end{array}$} & 100 & 0.1309 & 0.0790 & 0.8972 & 0.0238 \\
\hline & 200 & 0.2591 & 0.0674 & 0.8855 & 0.0471 \\
\hline & 300 & 0.3803 & 0.0563 & 0.8745 & 0.0691 \\
\hline & 400 & 0.4797 & 0.0473 & 0.8655 & 0.0872 \\
\hline & 500 & 0.5570 & 0.0403 & 0.8585 & 0.1013 \\
\hline & 600 & 0.6160 & 0.0349 & 0.8531 & 0.1120 \\
\hline
\end{tabular}



This report has been reproduced directly from the best available copy. It is available electronically on the Web (http://www.doe.gov/bridge).

Copies are available for sale to U.S. Department of Energy employees and contractors from:

Office of Scientific and Technical Information P.O. Box 62

Oak Ridge, TN 37831

(865) 576-8401

Copies are available for sale to the public from: National Technical Information Service

U.S. Department of Commerce

5285 Port Royal Road

Springfield, VA 22161

(800) 553-6847 


\section{Los Alamos} NATIONAL LABORATORY
EST.1943 